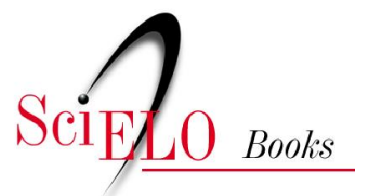

\title{
Delegados de polícia
}

\author{
Maria Tereza Sadek (org.)
}

SADEK, MT., org. Delegados de polícia [online]. Rio de Janeiro: Centro Edelstein de Pesquisas Sociais, 2009. 172 p. ISBN: 978-85-7982-014-4. Available from SciELO Books $<$ http://books.scielo.org $>$.

\section{(c) $\$(0)$}

All the contents of this chapter, except where otherwise noted, is licensed under a Creative Commons Attribution-Non Commercial-ShareAlike 3.0 Unported.

Todo o conteúdo deste capítulo, exceto quando houver ressalva, é publicado sob a licença Creative Commons Atribuição Uso Não Comercial - Partilha nos Mesmos Termos 3.0 Não adaptada.

Todo el contenido de este capítulo, excepto donde se indique lo contrario, está bajo licencia de la licencia Creative Commons Reconocimento-NoComercial-CompartirIgual 3.0 Unported. 


\section{BIBLIOTECA VIRTUAL DE CIÊNCIAS HUMANAS}

\section{Delegados De PolíCia}

\section{Maria Tereza Sadek (organizadora)}




\section{Maria Tereza Sadek}

Organizadora
Esta publicação é parte da Biblioteca Virtual de Ciências Humanas do Centro Edelstein de Pesquisas Sociais - www.bvce.org

Copyright (c) 2009, Maria Tereza Sadek

Copyright (c) 2009 desta edição on-line: Centro Edelstein de Pesquisas Sociais Ano da última edição: 2003, Sumaré.

Nenhuma parte desta publicação pode ser reproduzida ou transmitida por qualquer meio de comunicação para uso comercial sem a permissão escrita dos proprietários dos direitos autorais. A publicação ou partes dela podem ser reproduzidas para propósito não comercial na medida em que a origem da publicação, assim como seus autores, seja reconhecida.

ISBN: 978-85-7982-014-4

Centro Edelstein de Pesquisas Sociais

www.centroedelstein.org.br

Rua Visconde de Pirajá, 330/1205

Ipanema - Rio de Janeiro - RJ

CEP: 22410-000. Brasil

Contato: bvce@centroedelstein.org.br
Rio de Janeiro$$
2009
$$ 


\section{SUMÁrIO}

APRESENTAÇÃO 1

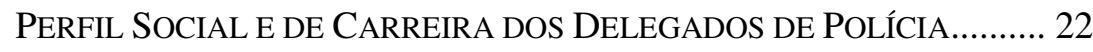
MARIA DA GLÓRIA BONELLI

A FoRMAÇÃO ACADÊMICA DOS DELEGAdOS DE POLÍCIA 51 HUMBERTO DANTAS

\section{Polícia Civil E SEGURANÇA PÚBlica:}

Problemas de Funcionamento e PERSPECTIVAS DE REFORMA... 72 ROGÉRIO BASTOS ARANTES

LUCIANA GROSS SIQUEIRA CUNHA

\section{Problemas e Desafios da Polícia CIVIL: As PerCePÇÕES dos}

DELEGADOS 107 ROSÂNGELA BATISTA CAVALCANTI

DELEGADA: DOUTORA E POLICIAL 126

\section{APRESENTAÇÃo}

Quem são e o que pensam os delegados de polícia? Para responder a essas perguntas, o Idesp realizou, com o apoio da Fundação Ford e da Fapesp, a mais ampla e inédita pesquisa sobre o perfil dos delegados de polícia no Brasil.

Em linha de continuidade com projetos anteriores que analisaram o perfil da magistratura ("O Poder Judiciário no Brasil", 1994-1995, e "A Visão dos Juízes sobre a Reforma do Judiciário", 2000-2001) e de integrantes do Ministério Público (“O Ministério Público e a Justiça no Brasil”, 1995-1996, e "O Ministério Público Federal e a Administração da Justiça no Brasil", 1997-1998), esta pesquisa pretende ampliar o conhecimento sobre o sistema de justiça no Brasil. Apesar da importância da Polícia no quadro dos órgãos responsáveis pela justiça e pela segurança pública, pouco se conhece sobre seus integrantes e sobre o que pensam a respeito dos problemas que afetam a instituição. O debate atual acerca desses problemas e de propostas de mudanças legislativas, processuais e organizacionais teria muito a ganhar com a elaboração de um perfil dos delegados de polícia e com a revelação de suas opiniões sobre a reforma da instituição e a melhoria da segurança pública no Brasil. Esses objetivos nortearam a presente pesquisa e seus principais resultados serão aqui apresentados.

\section{CARACTERÍSTICAS DO SURVEY E DEFINIÇÃO DA AMOSTRA}

Tendo em vista o objetivo de construir o perfil socioeconômico e ideológico dos delegados de polícia, com base na técnica de survey, selecionamos nove estados para compor a amostra da pesquisa: Amapá, Bahia, Distrito Federal, Goiás, Pernambuco, Paraná, Rio de Janeiro, Rio Grande do Sul e São Paulo. Tais escolhas procuraram representar diferentes regiões do país, graus variados de desenvolvimento social e econômico, condições políticas diversas, bem como diferentes experiências na área da polícia e segurança pública.

No que diz respeito ao número de entrevistas, estabelecemos e atingimos a meta de $20 \%$ do total de delegados de polícia em atividade nesses nove estados (com exceção do estado do Amapá, cujo pequeno 
contingente de delegados nos levou a elevar a amostra para cerca de $46 \%$ ). No total, 1.228 entrevistas foram realizadas, num complexo e difícil trabalho de campo que se estendeu do segundo semestre de 2001 até meados de 2002. A Tabela 1 traz informações sobre o universo e a amostra de delegados entrevistados.

Seguindo o mesmo procedimento de pesquisas anteriores, estratificamos a amostra por gênero e local de trabalho (capital do estado ou cidade do interior). Homens e mulheres foram representados conforme sua distribuição no universo das polícias de cada estado, assim como foi respeitada a proporção de delegados em atividade na capital e nos municípios do interior. Nos estados do Rio Grande do Sul, Paraná, São Paulo e Rio de Janeiro, os municípios da região metropolitana (com exceção da capital) foram agrupados em categoria específica. A distribuição do contingente de delegados por "classe" na carreira também foi observada, embora não tenha sido adotada como critério de estratificação da amostra (Tabela 1).

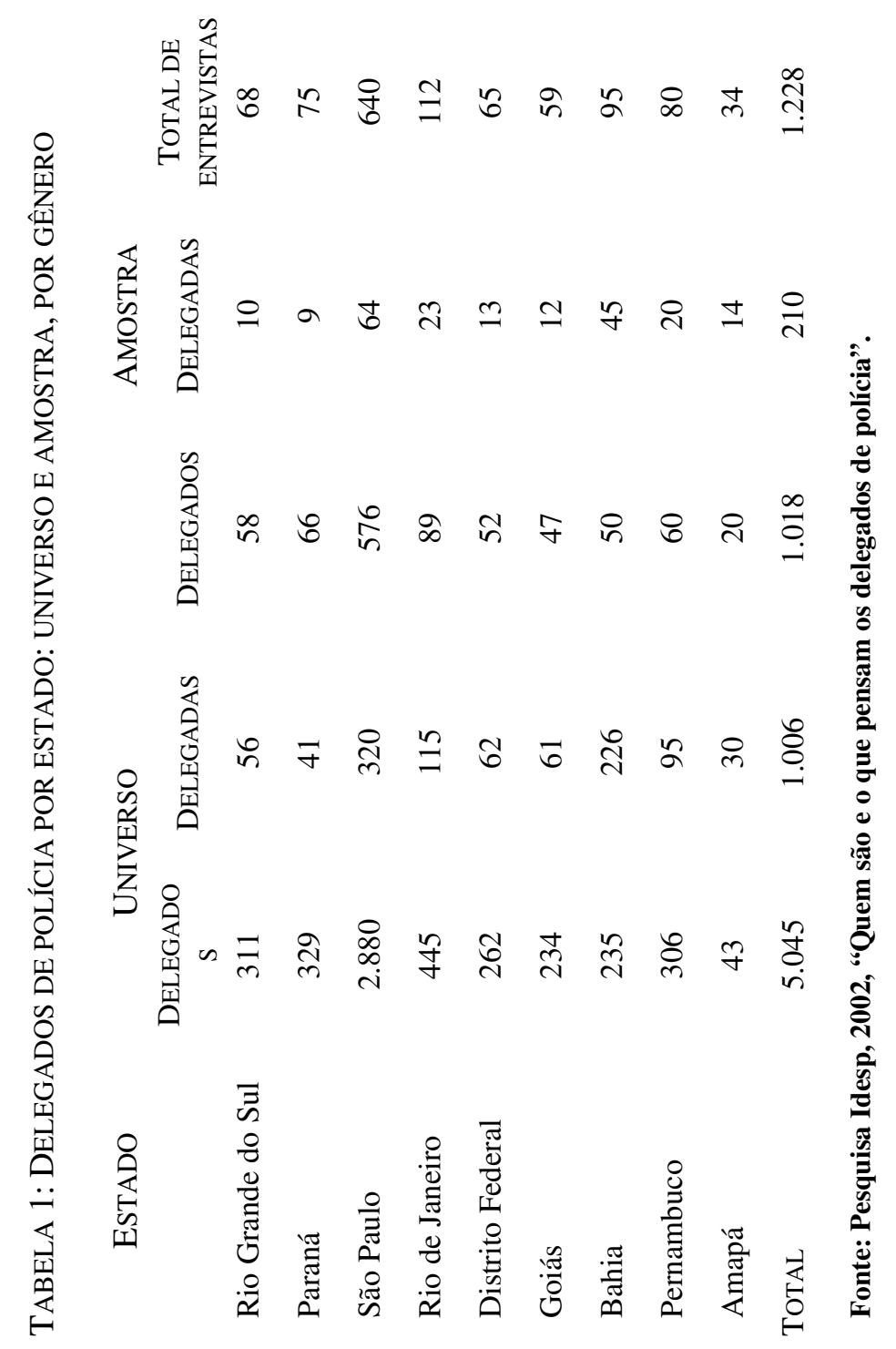




\section{MODELO DE QUESTIONÁRIO E METODOLOGIA DO TRABALHO DE CAMPO}

O questionário utilizado no survey seguiu o padrão que vem sendo desenvolvido pelo Idesp ao longo de dez anos de pesquisa com integrantes do sistema de justiça no Brasil. Para a sua confecção, realizamos entrevistas qualitativas com delegados selecionados e levantamos informações em fontes secundárias, desde documentos e publicações da polícia e associações de delegados até o noticiário de imprensa relativo aos temas da atividade policial e da segurança pública, passando pela bibliografia e debate acadêmicos existentes nessa área.

O questionário dividiu-se em duas partes principais: a primeira dedicou-se ao levantamento de dados pessoais e sobre a origem social dos delegados (idade, sexo, cor, grau de instrução dos pais, estado civil etc.), além de informações sobre a formação universitária, o ingresso na carreira, nível de remuneração, dentre outras. A segunda parte colheu a opinião dos entrevistados sobre a carreira do delegado de polícia (aspectos valorizados e motivos que os levaram a adotar essa profissão), sobre os obstáculos ao bom funcionamento da Polícia Civil e propostas para melhorar o desempenho da atividade policial, do sistema de segurança pública e para diminuir a impunidade e a criminalidade. Nessa parte, ouviu-se também a opinião sobre um conjunto de afirmações contundentes a respeito da atividade policial, sobre a imagem negativa da Polícia Civil e sobre o posicionamento ideológico (esquerda versus direita) dos delegados.

Com base na experiência de pesquisas anteriores com agentes do sistema de justiça, optamos pela aplicação dos questionários mediante entrevistas pessoais com os delegados de polícia. Para tanto, procuramos selecionar em cada estado pesquisadores que demonstrassem conhecimento da estrutura e funcionamento das instituições de justiça e segurança pública e que demonstrassem habilidade para enfrentar situações adversas, assegurando o caráter científico e acadêmico da pesquisa.

Os pesquisadores auxiliaram na finalização da amostra, mapeando a densidade "populacional" dos delegados por município e traçando estratégias de trabalho de campo segundo as peculiaridades locais. Eles puderam também estreitar o contato com as associações e direções estaduais da Polícia Civil, que facilitaram bastante o acesso aos delegados.
Em termos gerais, a aplicação dos questionários evoluiu muito bem em todos os estados e não chegamos a nos deparar com dificuldades intransponíveis. Pelo contrário, a grande maioria dos delegados ouvidos reconheceu a importância da pesquisa e elogiou o trabalho pioneiro do Idesp. Em termos qualitativos, o maior ganho do trabalho de campo foi a possibilidade de observar a rotina das delegacias de polícia e de seus agentes (delegados, investigadores, escrivães e demais funcionários). Nossos pesquisadores tiveram contato com realidades perversas e ambientes marcados pela precariedade de condições materiais e humanas, nos quais se passam as cenas mais diversas e por vezes dramáticas do cotidiano da população brasileira. Nesses locais, o delegado de polícia ocupa o papel central e muitos deles reagiram com um misto de surpresa e satisfação quando foram solicitados a falar de si mesmos e sobre os problemas da polícia e da segurança pública. Muitos aproveitaram a oportunidade para dramatizar a situação social em que vivem e clamar por mudanças na forma de tratamento da polícia, desejando que a pesquisa do Idesp contribua para os processos de revalorização da figura do delegado e de profunda reforma da organização policial.

Nessa perspectiva, é possível afirmar que a pesquisa do Idesp terá, no mínimo, o efeito de produzir uma espécie de "autoconhecimento" dos delegados de polícia, de sua carreira e de sua organização. Por essa razão, vários deles, bem como as direções estaduais e associações de classe, manifestaram forte desejo de discutir conjuntamente os resultados da pesquisa, além de expandi-la para outros temas e demais estados no futuro. Esperamos que a divulgação do presente relatório constitua um passo importante nessa direção. 
TABELA 2 - CARACTERÍSTICAS GERAIS DOS ENTREVISTADOS

GÊNERO

Masculino

Feminino

TOTAL

COR

Branca

Parda

Negra

Amarela

Vermelha

Não informaram

TOTAL

ESTADO CIVIL

Casado/união conjugal

Solteiro

Separado/divorciado/desquitado

Viúvo

Não informaram

TOTAL

IDADE

24 anos ou menos

De $25^{\mathrm{a}} 29$ anos

De 30 a 34 anos

De 35 a 39 anos

De 40 a 44 anos

De 45 a 49 anos

De 50 a 54 anos

De 55 a 59 anos

De 60 a 64 mais

65 anos ou mais

Não informaram

TOTAL

FREQUÊNCIA
1.018
210
1.228
FREQUÊNCIA
1.028
140
38
16
2
4
1.2284

82,9

17,1

00,0

83,7

11,4

3,1

1,3

0,2

0,3

100,0

$\begin{array}{cc}\text { FREQUÊNCIA } & \% \\ 879 & 71,6\end{array}$

$203-16,5$

$135 \quad 11,0$

60,5

$\begin{array}{cc}5 & 0,4 \\ 1.228 & 100,0\end{array}$

FREQUENCIA \%

$\begin{array}{cc}1 & 0,1 \\ 72 & 5,9 \\ 168 & 13,7 \\ 259 & 21,1 \\ 229 & 18,7 \\ 196 & 16,0 \\ 143 & 11,7 \\ 76 & 6,2 \\ 57 & 4,6 \\ 22 & 1,8 \\ 5 & 0,4 \\ 1.228 & 100,0\end{array}$

Do total de 1.228 entrevistados, $82,9 \%$ são do sexo masculino e $17,1 \%$ do sexo feminino. A média de idade dos entrevistados é de 43 anos. A maioria é formada por brancos $(83,7 \%)$; os pardos representam 11,4\%; os negros 3,1\%; os amarelos 1,3\%; e 0,3\% não informaram a cor. Quanto ao estado civil, 71,6\% são casados; $16,5 \%$ são solteiros; $11,0 \%$ separados, divorciados ou desquitados; $0,5 \%$ viúvos e $0,4 \%$ não informaram (Tabela 2).
Com relação ao grau de instrução paterna e materna, $70,1 \%$ dos pais e 78,4\% das mães dos entrevistados não possuem cursos universitários, indicando a mobilidade educacional ascendente dos delegados, profissão que requer o título de bacharel em Direito (Tabela 3).

TABELA 3: GRAU DE INSTRUÇÃO DOS PAIS

\begin{tabular}{lcccc} 
& \multicolumn{2}{c}{ PAI } & \multicolumn{2}{c}{ MÃE } \\
Sem instrução formal & 73 & 5,9 & 80 & 6,5 \\
$1^{\circ}$ grau incompleto & 268 & 21,8 & 253 & 20,6 \\
$1^{\circ}$ grau completo & 206 & 16,8 & 242 & 19,7 \\
$2^{\circ}$ grau incompleto & 68 & 5,5 & 71 & 5,8 \\
$2^{\circ}$ grau completo & 210 & 17,1 & 288 & 23,5 \\
Universitário incompleto & 37 & 3,0 & 28 & 2,3 \\
Universitário completo & 349 & 28,4 & 214 & 17,4 \\
Não informaram & 17 & 1,4 & 52 & 4,2 \\
TOTAL & 1.228 & 100,0 & 1.228 & 100,0
\end{tabular}

Fonte: Pesquisa Idesp, 2002, “Quem são e o que pensam os delegados de polícia”.

Entre os entrevistados, 61,5\% não têm parentes na Polícia Civil enquanto $37,9 \%$ têm, indicando a proporção de recrutamento exógeno e endógeno, respectivamente (Tabela 4).

\section{TABEla 4: PARENTES NA POLÍCIA CIVIL}

$\begin{array}{lcc} & \text { FREQUÊNCIA } & \% \\ \text { Não } & 755 & 61,5 \\ \text { Sim } & 465 & 37,9 \\ \text { Não informaram } & 8 & 0,7 \\ \text { TOTAL } & 1.228 & 100,0\end{array}$

Fonte: Pesquisa Idesp, 2002, “Quem são e o que pensam os delegados de policia”.

A maioria expressiva dos delegados exerceu alguma atividade profissional antes de ingressar na carreira (92,3\%). Apenas 7,6\% afirmaram não ter exercido nenhuma atividade anteriormente (Tabela 5).

Mais de dois terços dos delegados passaram a desempenhar a função depois da vigência da Constituição Federal de 1988 (Tabela 6).

A capacidade de preparar inquéritos bem circunstanciados, o saber jurídico, a competência técnica para o trabalho de investigação e saber 
trabalhar em equipe foram apontados por aproximadamente três quartos dos entrevistados como as características mais importantes para ser bom delegado (Tabela 7).

Motivos altruísticos, como a defesa do cidadão e a oportunidade de prestar serviços à comunidade, foram indicados como os mais importantes, dentre os fatores que influenciaram a decisão de ingressar na carreira de delegado. Apareceram também como fatores menos importantes para a escolha da profissão a falta de opção no mercado de trabalho e a orientação de professores na faculdade (Tabela 8).

\section{TABELA 5: EXERCÍCIO DE ATIVIDADE PROFISSIONAL ANTERIOR}

$\begin{array}{lcc} & \text { FREQUÊNCIA } & \% \\ \text { Não } & 93 & 7,6 \\ \text { Sim } & 1.134 & 92,3 \\ \text { Não informaram } & 1 & 0,1 \\ \text { TOTAL } & 1.228 & 100,0\end{array}$

Fonte: Pesquisa Idesp, 2002, "Quem são e o que pensam os delegados de polícia”.

\section{TABELA 6: ANO DE POSSE NO CARGO}

Antes de 1964

De 1965 a 1968

De 1969 a 1972

De 1973 a 1976

De 1977 a 1980

De 1981 a 1984

De 1985 a 1988

De 1989 a 1992

De 1993 a 1996

De 1997 a 2000

Após 2001

Não informaram

TOTAL

FREQUÊNCIA
5
7
14
55
34
78
202
313
264
193
53
11
1.228

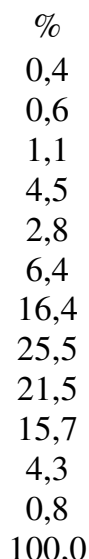

Fonte: Pesquisa Idesp, 2002, “Quem são e o que pensam os delegados de polícia”. $\begin{array}{llllllllll}\vec{t} & 0 & 0 & 0 & 0 & 0 & 0 & 0 & 0 \\ \dot{0} & 0 & 0 & 0 & \dot{0} & 0 & \dot{0} & \dot{8} & \dot{8}\end{array}$

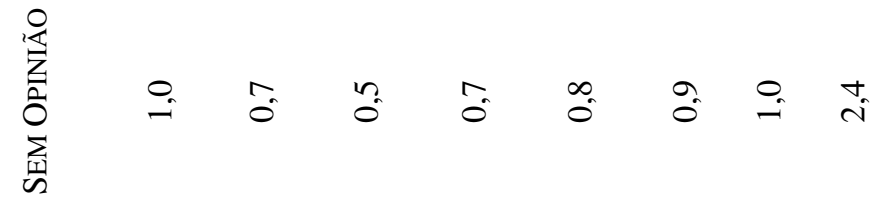

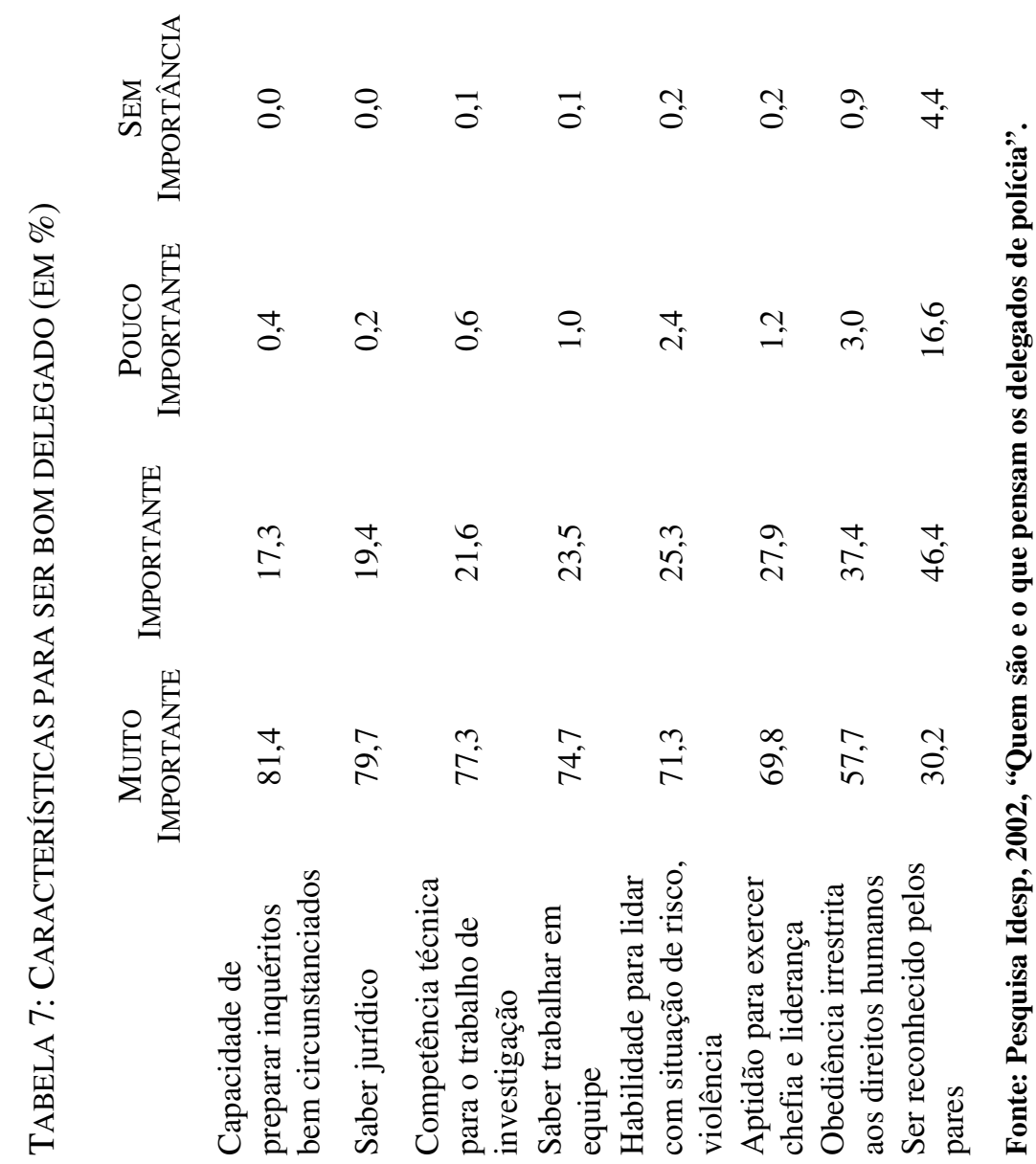




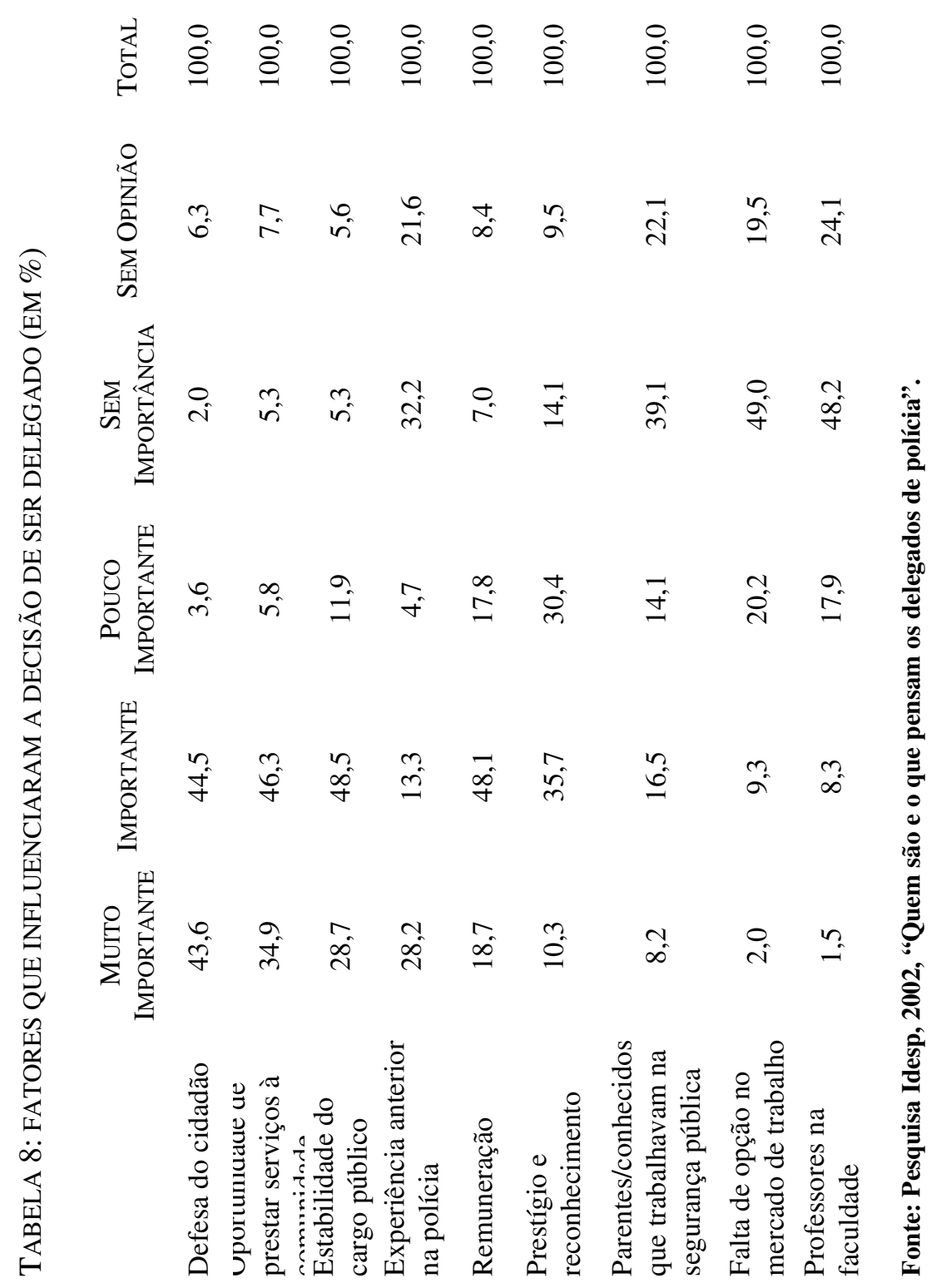

10
Por outro lado, os fatores que têm representado obstáculos ao bom funcionamento da Polícia Civil foram, em primeiro lugar, a falta de empenho governamental na implementação de políticas de segurança, seguida da interferência política na cúpula da instituição e, em terceiro lugar, a ocupação do cargo de Secretário de Segurança por leigos em segurança pública. O conflito de atuação com a Polícia Militar e a interferência do Ministério Público na atividade policial dividiram mais a opinião dos delegados. No primeiro caso, $54,4 \%$ consideram o conflito de atuação com a PM um obstáculo relevante (somados "muito importante" e "importante") e 41,2\% não (somados "pouco importante" e "sem importância"). No segundo caso, 59,2\% consideram a interferência do MP um obstáculo relevante (somados "muito importante" e "importante") e 37,7\% não (somados "pouco importante" e "sem importância") (Tabela 9).

A promulgação da lei orgânica é vista por $82,6 \%$ dos entrevistados como muito importante para melhorar o funcionamento da Polícia Civil. Recebem também um alto índice de apoio a eleição para delegado geral pelos integrantes da carreira (77,9\%), a definição de critérios objetivos para promoção e ocupação de cargos de direção $(77,7 \%)$ e a inamovibilidade dos delegados $(77,0 \%)$. Por outro lado, a proposta que prevê o controle externo da atividade policial pelo Ministério Público é rejeitada por $78,6 \%$ dos entrevistados, que a consideram pouco importante ou sem importância para melhorar o funcionamento da Polícia Civil (Tabela 10).

Todas as propostas listadas na Tabela 11 recebem apoio expressivo dos delegados, com exceção da ideia de unificação das polícias Civil e Militar (que encontra alguma resistência em pelo menos 26,7\% dos entrevistados, que discordam em termos ou totalmente da proposta) e da criação/fortalecimento da Ouvidoria de Polícia (que teve a discordância total ou parcial de $28,7 \%$ dos entrevistados). 


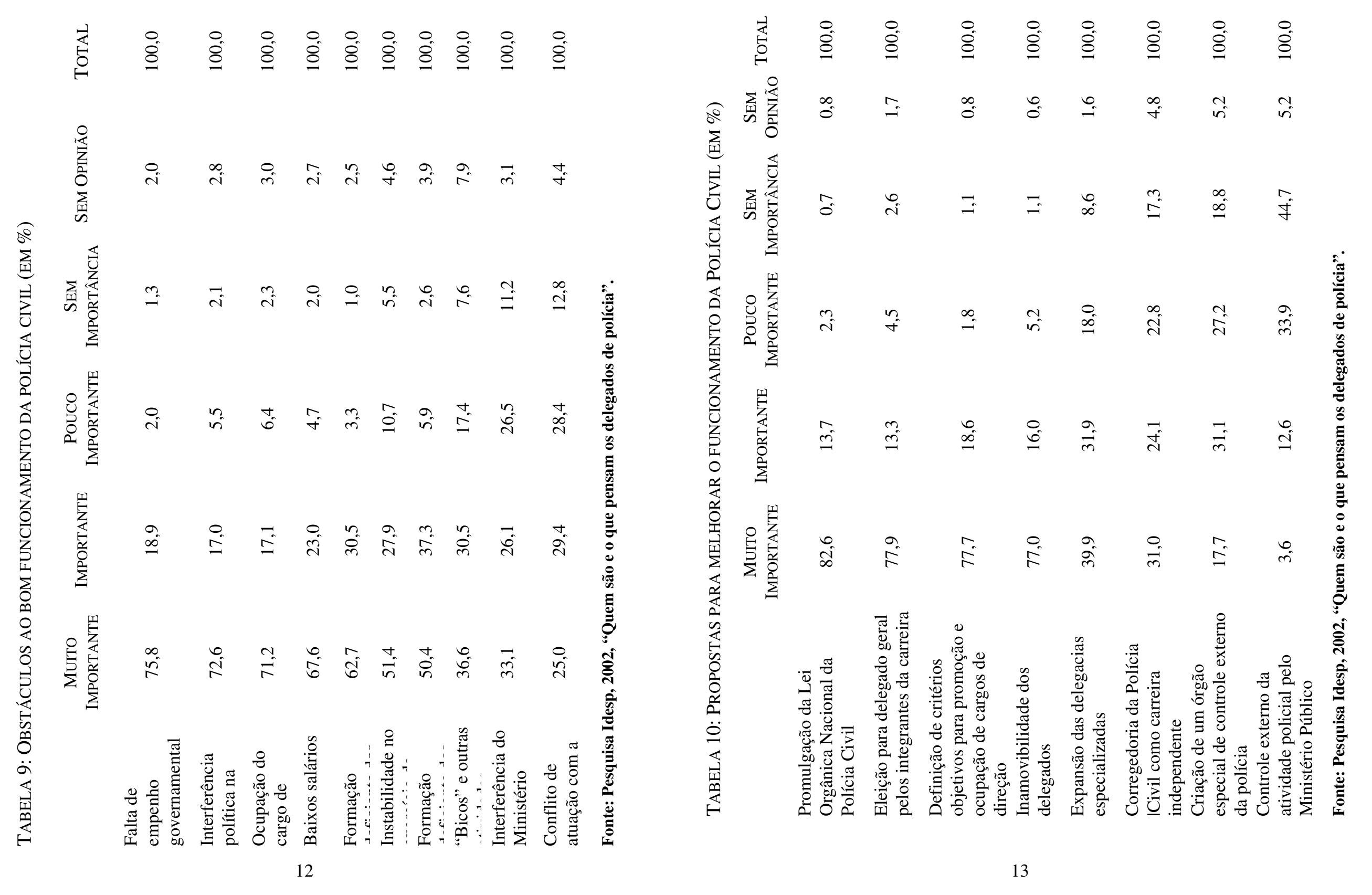




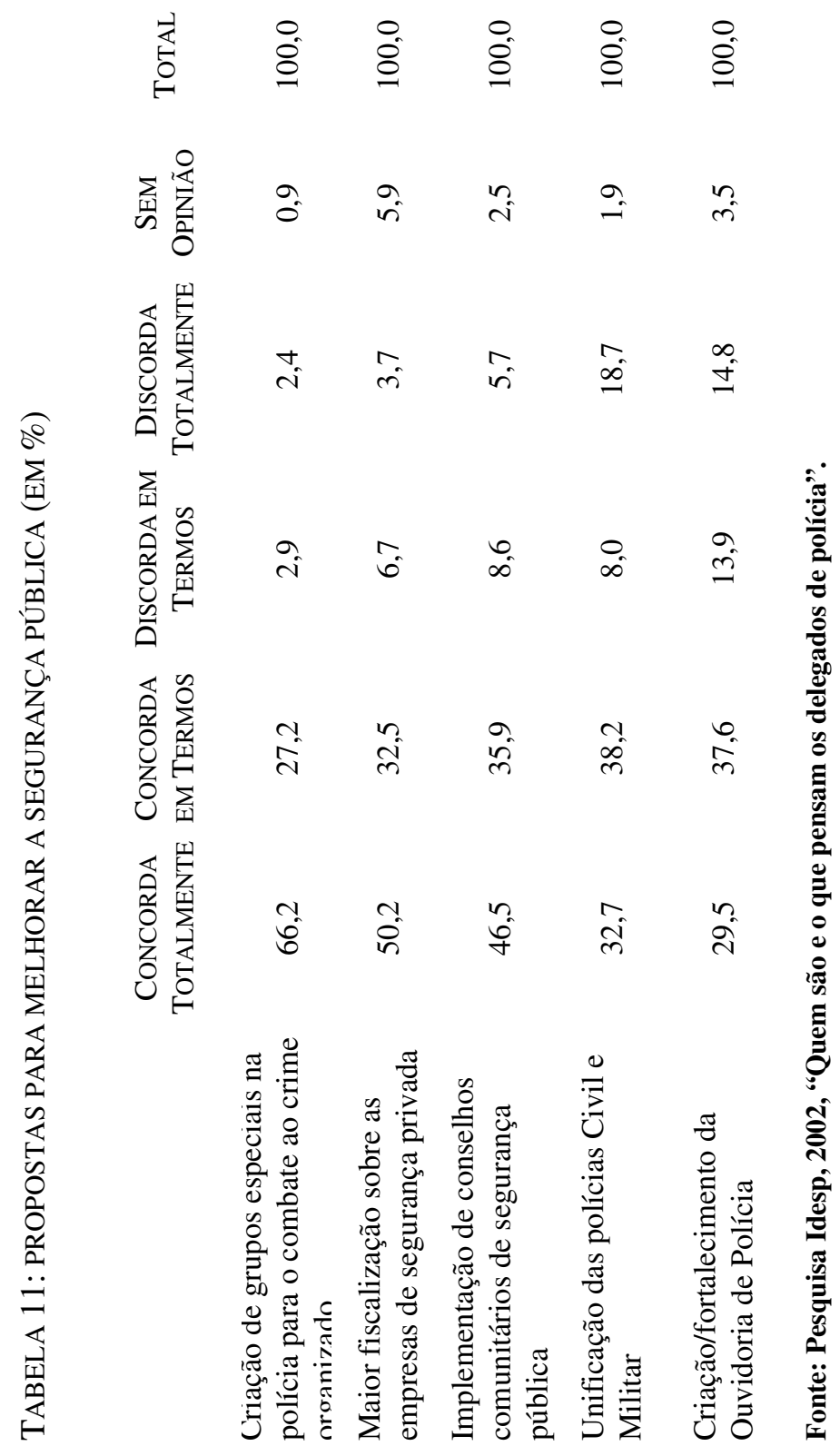

É quase unânime o apoio à proposta que prevê o plantão judiciário de 24 horas. Mais da metade dos entrevistados concorda totalmente com as propostas que permitem ao delegado de polícia realizar busca domiciliar sem mandado judicial $(64,5 \%)$ e com a diminuição da maioridade penal de 18 para 16 anos $(52,3 \%)$. Por outro lado, é expressivo o grau de rejeição à interferência do Ministério Público na atividade de investigação policial, seja na direção dos trabalhos $(91,4 \%)$, seja na criação de grupos de investigação dentro do próprio Ministério Público (84,6\%) (Tabela 12).

"Bons e maus cidadãos devem ter seus direitos constitucionais respeitados" é a afirmação que recebe o maior percentual de concordância total $(75,8 \%)$. Em contraste, é expressivo o número de entrevistados que manifestou discordância total em relação as seguintes afirmações: "a democracia abalou a autoridade policial" $(64,1 \%)$; "a confissão sob pressão policial é justificável nos casos de crimes hediondos" (62,5\%) e "a violência é inerente à função policial" (62,2\%) (Tabela 13).

Acusações de corrupção são vistas como o principal fator responsável pela formação de uma imagem negativa da Polícia Civil (77,5\%). Contribuem também para essa imagem a exploração sensacionalista pelos meios de comunicação, o tratamento dispensado à população e a violência policial. $\mathrm{O}$ menor peso, dentre todos os fatores apresentados, é atribuído às declarações de integrantes do Poder Judiciário (Tabela 14).

A relação da Polícia Civil com as demais instituições e com a população é vista, em geral, como positiva. Os delegados avaliam como ótima ou boa a relação com o Poder Judiciário $(68,0 \%)$; com os grupos privilegiados da população $(65,6 \%)$ e com os setores desfavorecidos da população $(54,3 \%)$. A relação mais problemática, segundo os entrevistados, é com o Ministério Público (Tabela 15). 

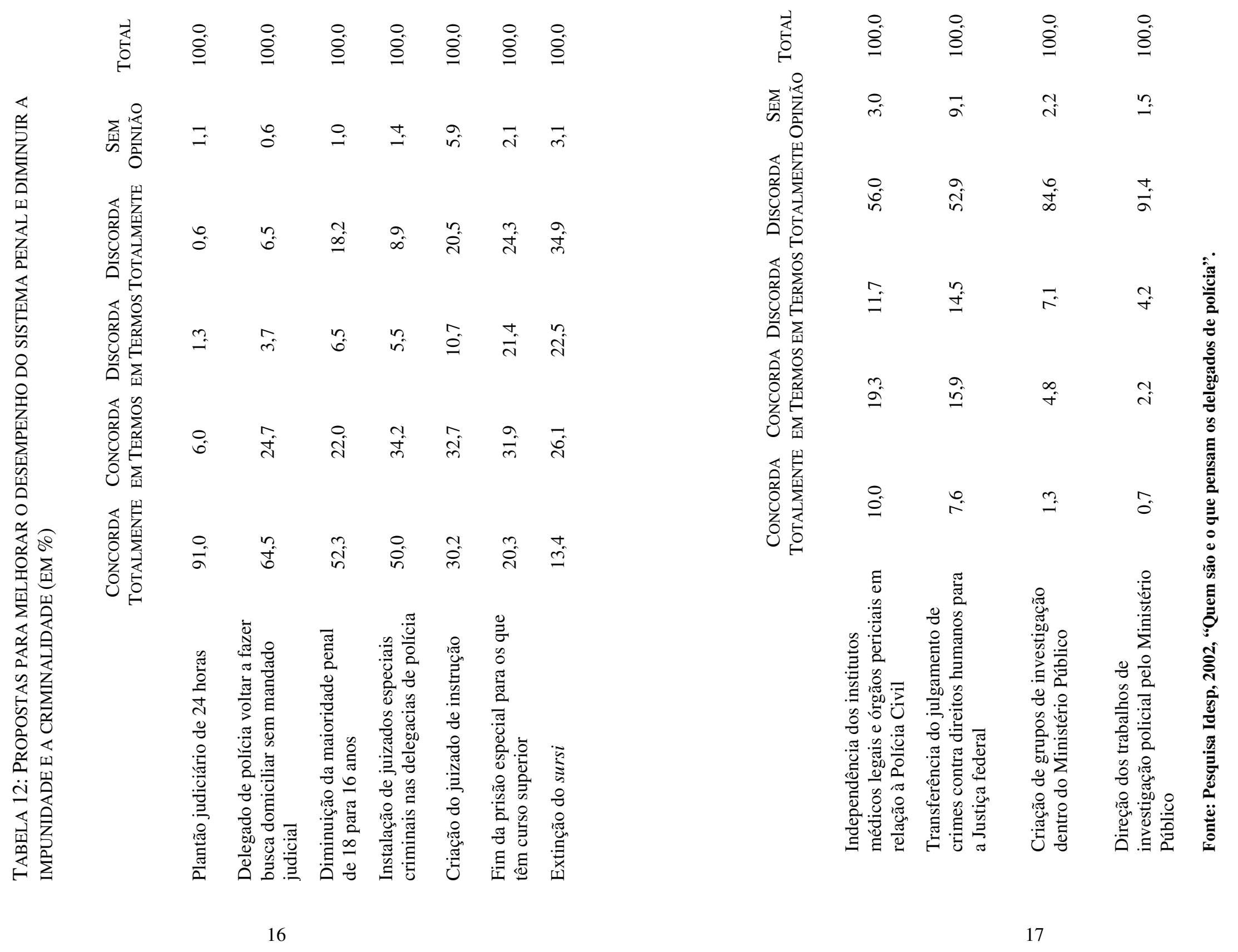


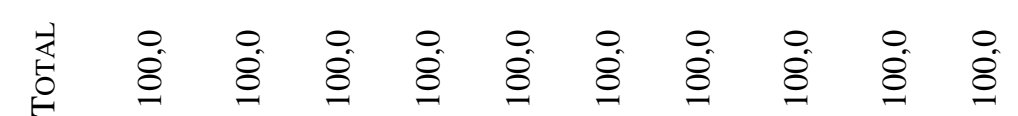
瓷爱

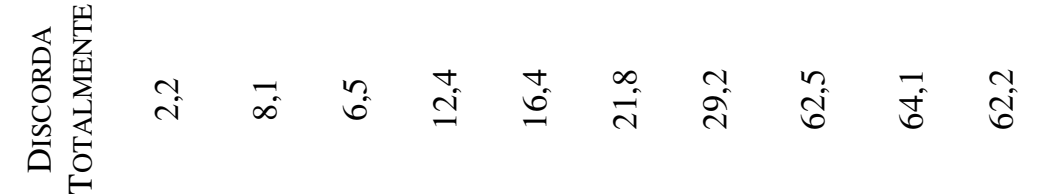

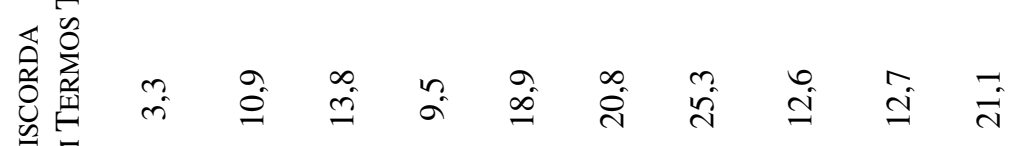
通敦高

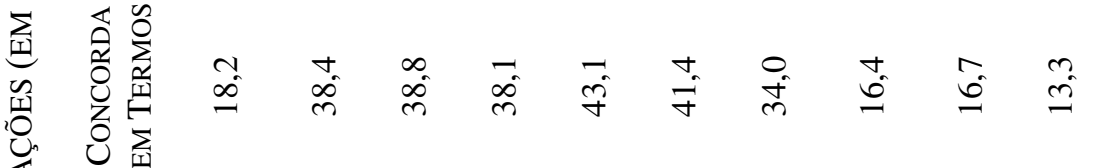

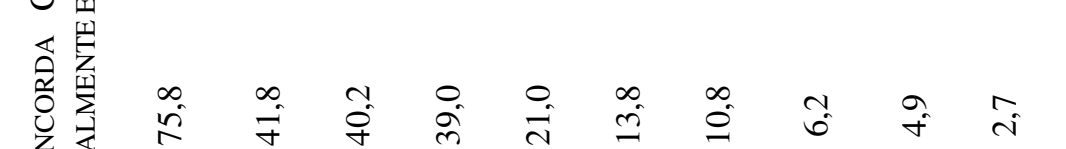
ठठ

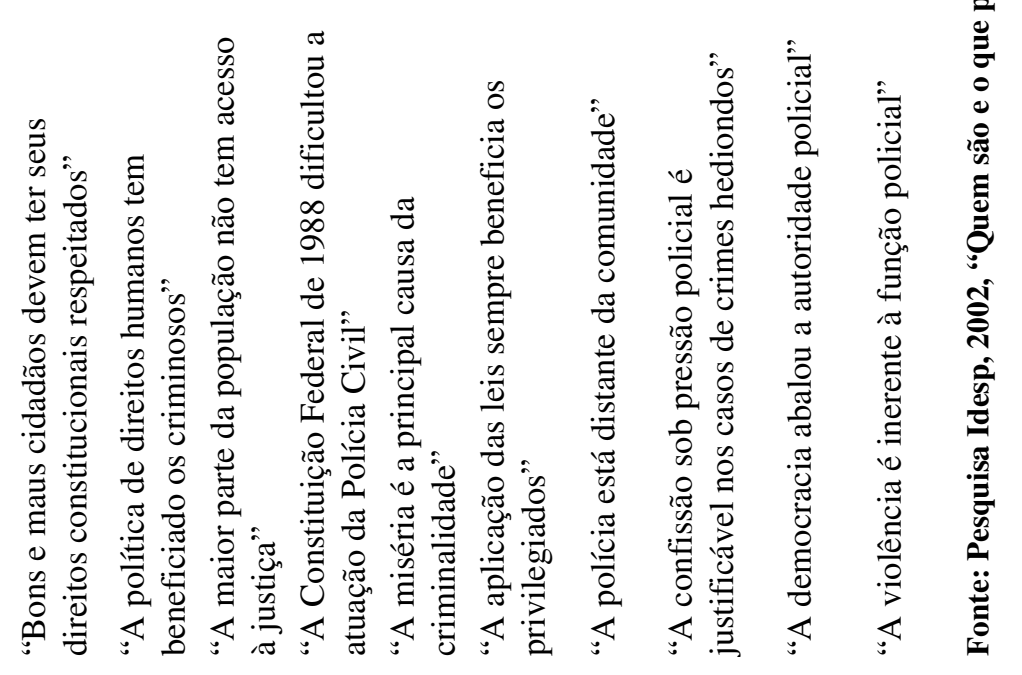

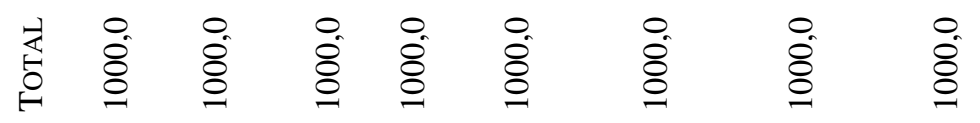

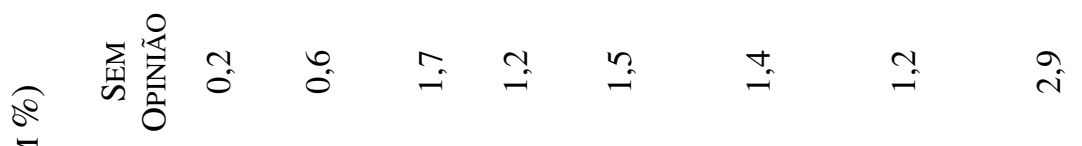

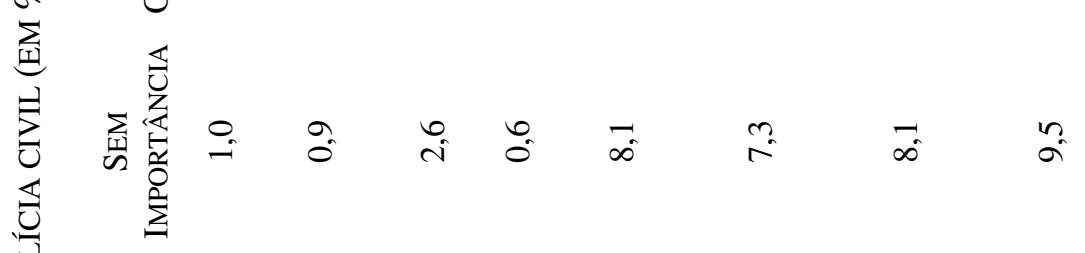

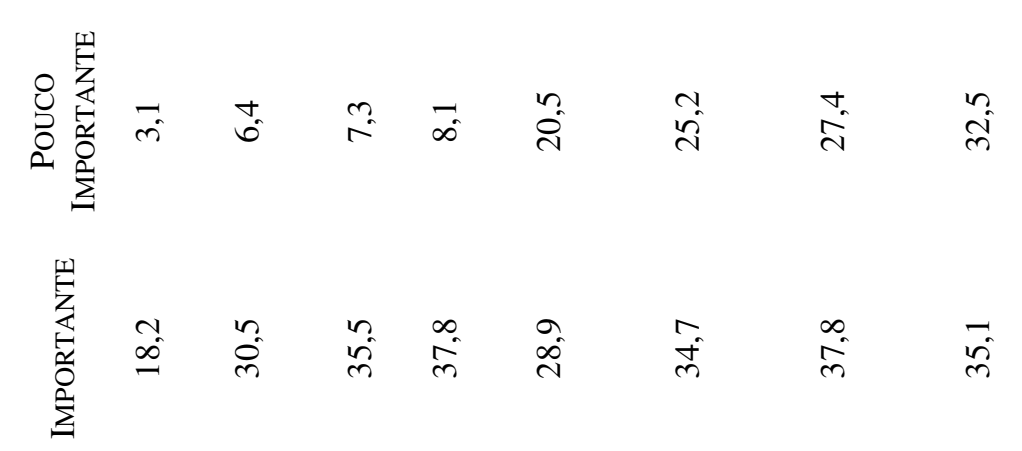
茎造

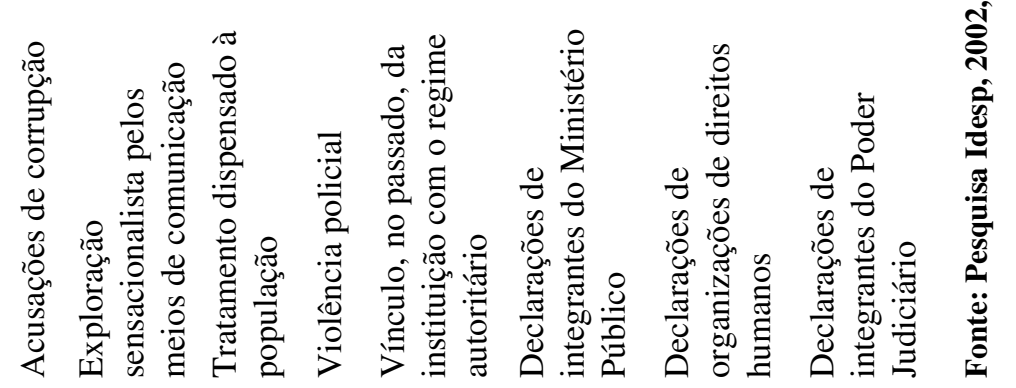




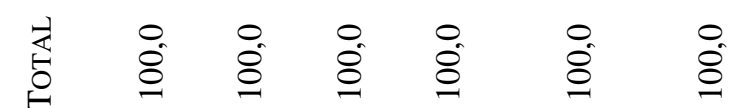

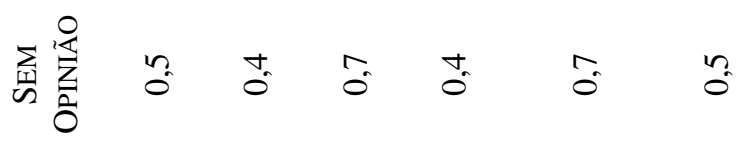

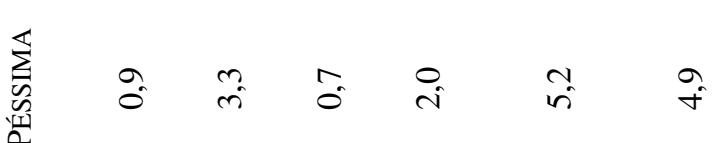

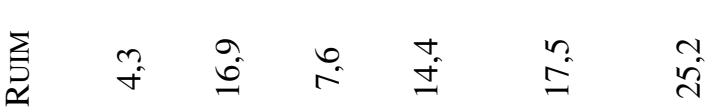

ำ

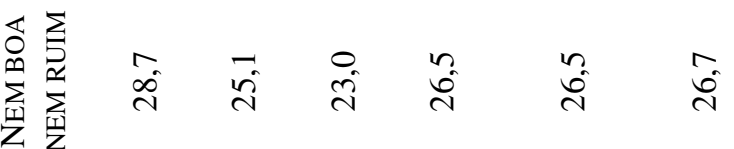

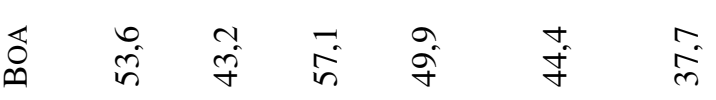

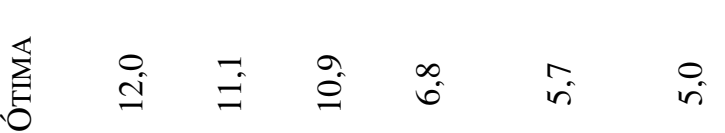

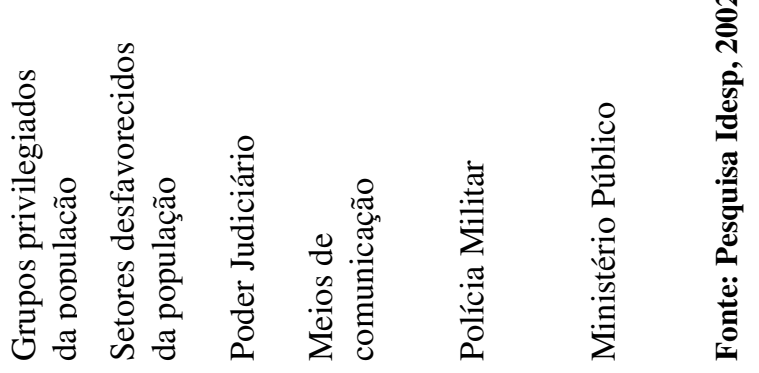

A maioria dos entrevistados considera-se de centro $(48,5 \%)$ e os demais dividem-se quase ao meio entre posições mais à esquerda $(25,9 \%$, se somadas "centro-esquerda" e "esquerda") e mais à direita $(22,8 \%$, se somadas "centro-direita" e "direita"). Apenas 2,8\% disseram não ter opinião a respeito ou não quiseram responder à questão (Tabela 16).

TABELA 16 - POSICIONAMENTO IDEOLÓGICO

\begin{tabular}{|c|c|c|}
\hline & UENCIA & \\
\hline Esquerda & 29 & 2,4 \\
\hline Centro-esquerda & 289 & 23,5 \\
\hline Centro & 595 & 48,5 \\
\hline Centro-direita & 244 & 19,9 \\
\hline Direita & 36 & 2,9 \\
\hline Sem opinião & 35 & 2,8 \\
\hline TOTAL & 1.228 & 100,0 \\
\hline
\end{tabular}

Fonte: Pesquisa Idesp, 2002, “Quem são e o que pensam os delegados de polícia”. 


\section{Perfil Social e de Carreira dos Delegados de Polícia}

Maria da Glória Bonelli

Historicamente, os delegados de polícia têm sido o grupo profissional na área jurídica mais atrelado ao governo e sujeito à interferência política. A origem deste quadro funcional no Brasil é iniciativa do poder central do Império, em 1841, visando impor a ordem centralizadora e controlar a resistência existente nas localidades a uma estrutura hierárquica para a polícia judicial e investigativa. As raízes da função foram politizadas com o uso do cargo para garantir o predomínio da autoridade do imperador e do gabinete sobre o poder local, substituindo o juiz de paz pela gradação chefe de polícia - delegado de polícia - subdelegado, no contexto de derrota das concepções descentralizadoras que marcaram o período regencial.

A preocupação com a ordem pública e a montagem de um aparato repressivo para garantir o status quo foi inicialmente contemplada com a constituição da Polícia Militar, em 1831, e da Secretaria de Polícia, em 1833.

Os cargos de chefe de polícia e de delegado criaram as condições para a organização hierárquica da polícia, instituindo-se o controle civil sobre o policiamento militar, em 1842 (Holloway, 1997). Tal modelo burocrático não foi pensado para insular essas atividades da politização, mas para derrotar o adversário político - o mandonismo local.

Em maior ou menor grau, tal marca de nascença continua na carreira até hoje, nos nove estados brasileiros focalizados nesta pesquisa. $\mathrm{O}$ profissionalismo, que é a alternativa que o mundo do Direito desenvolveu para consolidar sua independência atuando tão próximo ao Estado, encontrase mais embrionário entre os delegados de polícia. Vários são os obstáculos para que o ethos profissional torne-se dominante entre as autoridades policiais, como as características sociais do grupo, as práticas e o ideário predominante, o percurso profissional, o padrão da institucionalização da atividade, a estrutura da carreira, a posição no campo jurídico, as relações com o governo e com a política convencional.
O modelo profissional de organização do trabalho diferencia-se dos modelos da burocracia e do livre mercado, protegendo-se das lógicas que imperam nessas outras formas. O princípio da livre concorrência baseia-se na interpretação de que, idealmente, a oferta e a procura seriam as regras básicas a orientar a competição. Os consumidores escolheriam os produtos e os serviços que lhes fossem mais adequados, ponderando custos e benefícios. A título de exemplo, aqueles que preferissem ser representados em um processo judicial por um leigo, em vez de um advogado, teriam essa escolha no sistema de justiça, de acordo com o modelo do livre mercado, o que hoje só é permitido no Juizado Especial de Pequenas Causas, em ações até vinte salários mínimos. Esse tipo ideal considera a profissionalização como um recurso corporativo. Por outro lado, o modelo burocrático baseia-se no entendimento de que cabe ao Estado controlar funcionários hierarquicamente, que executariam ordens comandadas de cima para baixo, sem participar de sua formulação. Segundo essa concepção, o formato do profissionalismo seria muito autônomo, dificultando o controle externo e alimentando a resistência a obedecer ordens.

A lógica ocupacional que orienta o profissionalismo diferencia-se da livre concorrência e da hierarquização da burocracia. Ele é um modo alternativo de organizar o trabalho que reúne cinco atributos: a) status especial na força de trabalho proveniente de um corpo teórico de conhecimento e habilidades discricionárias; b) jurisdição exclusiva sobre uma dada atividade negociada com outras ocupações; c) controle de mercado pelos pares; d) posse do diploma superior; e) ideologia que priorize o compromisso com a realização de um bom trabalho em vez do ganho financeiro e da qualidade em vez da eficiência econômica da atividade (Freidson, 2001, p.127). Os profissionais valorizam as relações horizontalizadas entre colegas, a opinião dos pares com quem partilham o conhecimento científico comum, a autonomia para realizar os diagnósticos e para solucionar os quebra-cabeças de sua especialização.

Na trajetória que as profissões do Direito percorreram no Brasil, os advogados e os magistrados alcançaram o profissionalismo antes dos promotores de justiça, que consolidaram este modelo de Ministério Público, com a Constituição de 1988. Essa é a bandeira que a Associação Nacional dos Delegados de Polícia vem empunhando junto aos congressistas, na discussão da reforma constitucional em debate atualmente. Suas lideranças buscam uma Lei Orgânica Nacional para a Polícia Civil que aproxime a carreira de delegado do modelo profissional. Conquistar o insulamento para proteger a função da 
interferência política requer, além de leis, que o grupo partilhe dessa prática e oriente-se pelo ideário que lhe é próprio. Identificar o perfil social e ideológico dos delegados de polícia, hoje, fornece elementos para avaliar que fatores impulsionam ou constrangem a consolidação do profissionalismo no grupo.

\section{MORFOLOGIA SOCIAL DOS DELEGADOS}

No total da amostra, o grupo é predominantemente masculino, mas alguns estados já contam com uma parcela expressiva de delegadas, ultrapassando a casa dos 40\%, como na Bahia e no Amapá (Tabela 1). Foi nos estados em que a carreira encontrava-se menos profissionalizada que as mulheres conseguiram expandir sua atuação mais rapidamente.

\section{TABEla 1: DistribuiçÃo DOS DELEGAdOS SEGUNDO O SEXO, POR ESTADO}

$\begin{array}{lccc}\text { Estado } & \text { MASCUlinO }(\%) & \text { FEMININO }(\%) & \text { TOTAL }(\mathrm{N}) \\ \text { Amapá } & 58,8 & 41,2 & 34 \\ \text { Bahia } & 52,6 & 47,4 & 95 \\ \text { Distrito Federal } & 80,0 & 20,0 & 65 \\ \text { Goiás } & 79,7 & 20,3 & 59 \\ \text { Pernambuco } & 75,0 & 25,0 & 80 \\ \text { Paraná } & 85,3 & 14,7 & 75 \\ \text { Rio de Janeiro } & 79,5 & 20,5 & 112 \\ \text { Rio Grande do Sul } & 85,3 & 14,7 & 68 \\ \text { São Paulo } & 90,0 & 10,0 & 640 \\ \text { TOTAL } & 82,7 & 17,3 & 1.228\end{array}$

Fonte: Pesquisa Idesp 2002, “Quem são e o que pensam os delegados de polícia”.

Onde a institucionalização da atividade começou mais cedo, como é o caso de São Paulo que estabeleceu a carreira em 1906, a participação feminina ainda estava na faixa dos $10 \%$ quando realizamos a pesquisa de campo. Normalmente, as regulamentações profissionais elevam o prestígio do grupo, favorecendo os segmentos que as viabilizaram. Embora introduzam mudanças no momento que são estabelecidas, as carreiras, passada a fase de sua organização, sedimentam trajetórias, etapas a serem percorridas e posições no campo. A base do processo de profissionalização é o fechamento do mercado, protegendo-o da competição com outras ocupações por meio do domínio de uma jurisdição exclusiva. Em sua composição interna tem o efeito de estratificar o grupo. As práticas e valores sedimentados junto com essa forma de organização do trabalho atuam também para preservar os setores dominantes dentro da profissão, mudando mais lentamente o perfil do grupo.

No caso do Amapá, o que favorece o rápido ingresso feminino é o fato de a carreira de delegado da Polícia Civil ter sido criada após a transformação do território em estado, com a Constituição de 1988. Os que foram nomeados antes dos anos de 1990 pertenciam à Polícia Federal e foram incorporados ao quadro estadual. $O$ primeiro concurso foi realizado em 1992, aprovando 44 candidatos. Desses, mais da metade já havia saído da polícia em 2002. Como as demais carreiras jurídicas públicas estaduais no Amapá foram organizadas nos anos de 1990, surgindo novos concursos para a Magistratura e o Ministério Público, com remuneração significativamente melhor, isto pode ter tido consequência para a feminização da atividade de delegado de polícia. No Amapá, o salário inicial para os delegados é de $\mathrm{R} \$ 2.600,00$ e o de juízes e promotores é de $\mathrm{R} \$$ 6.000,00. Os estudos sobre aumento da participação feminina no mercado de trabalho de nível superior apontam para um padrão de ingresso impulsionado pela exigência do diploma, havendo bom desempenho discente das mulheres durante a faculdade, e pelo desinteresse dos homens por certas atividades, devido à baixa remuneração ou perda nos ganhos, no poder e/ou no prestígio da ocupação.

A intensa mudança na composição de gênero na carreira, na Bahia, também foi possibilitada por seu reduzido grau de institucionalização, acompanhado de problemas salariais. Esse estado não possuía legislação que impedisse o acesso à função sem formação superior em Direito e sem realização de concurso público. Também está entre as polícias mais mal pagas do país, tendo enfrentado um forte movimento grevista em 2001. A partir da determinação constitucional estabelecendo a obrigatoriedade do diploma para o exercício do cargo, foram abertos dois concursos públicos para substituir os delegados "calça-curtas", o que consolidou a participação feminina. Maria Cândida Bahia (2002) realizou um estudo sobre a atuação das mulheres na função de delegada na polícia baiana, que permite identificar características dessa profissionalização.

\footnotetext{
${ }^{1}$ Os delegados de polícia referem-se assim aos colegas que exercem a atividade sem possuir o diploma de bacharel em Direito.
} 
Na verdade, a policial civil feminina, na Bahia, já estava trabalhando junto ao homem antes da reestruturação de $1976^{2}$. Em 1972, foi realizado o primeiro concurso público para o preenchimento do cargo de delegado(a) de polícia e o primeiro curso de aperfeiçoamento, no qual dos trinta participantes, quatro mulheres obtiveram o certificado de conclusão. No entanto, a partir de 1986, quando 26 delegadas foram aprovadas em uma turma de 43 candidatos, a escalada das mulheres não parou de crescer. No concurso de 1994, 53\% dos aprovados foram mulheres, num cenário em que elas representavam $45 \%$ do total de delegados. Esta ascensão culminou com a nomeação de uma mulher, no ano de 1999, para ocupar o cargo máximo da Polícia Civil - a Secretaria de Segurança Pública do Estado (Bahia, 2002, p.95)

Após a realização do trabalho de campo, a Polícia Civil baiana concluiu o segundo concurso, no qual $70 \%$ dos aprovados eram mulheres. Hoje, a carreira já conta com predomínio feminino, com mais da metade do corpo profissional.

Quanto à mobilidade geográfica dos delegados, tomando-se como referências o local de nascimento e o estado onde atuavam, a Bahia encontra-se entre aqueles com menores porcentagens de absorção de migrantes na carreira, junto com o Rio Grande do Sul e São Paulo. Esses três casos apresentaram percentagens superiores a $90 \%$ de delegados nascidos no estado onde exerciam a função. A maior incidência de migrantes foi obtida nos estados de criação mais recente, como o Amapá, com grande participação de paraenses e o Distrito Federal, que, além das características de sua origem e ocupação por meio da migração interna, exerceu forte atração de mineiros, cariocas e paulistas para a carreira.

A peculiaridade do Distrito Federal é que o concurso feito em 1998 teve realização de provas em vários estados brasileiros, além da capital do país, o que favoreceu a inscrição de bacharéis de outras regiões, estimulando a migração entre os 160 selecionados. Tal como o Amapá, o Distrito Federal passou a ser uma unidade da federação com a Constituição de 1988, com eleição para governador. Isto gerou expansão de municípios, avanço demográfico e aumento da violência urbana, ampliando o corpo

\footnotetext{
${ }^{2}$ Trata-se do Programa de Modernização Administrativa da Secretaria de Segurança Pública, que criou a Polícia Civil da Bahia. A guarda civil havia sido incorporada à Polícia Militar em 1969.
}

profissional da Polícia Civil com novos concursos e novas posses de delegados a partir de 1995.

Quanto à autoclassificação de cor dos delegados, há o predomínio de brancos, com uma distribuição decrescente no percentual obtido entre os estados. Acima dos $90 \%$ estão São Paulo e Rio Grande do Sul e abaixo de $50 \%$ estão o Amapá e a Bahia, com expressiva população parda. O estado com a maior concentração de delegados negros é a Bahia, com 12,6\%. O Distrito Federal, além de atrair migrantes e jovens, tem uma parcela de $34 \%$ de delegados pardos.

De acordo com a Tabela 2, cerca de $60 \%$ da amostra têm mais de 40 anos. Distrito Federal e Amapá são os estados que possuem um contingente mais novo, já que a maioria das contratações ocorreu na década de 1990. Se considerarmos a idade média de ingresso na carreira para o total da amostra, ela foi de 32,3 anos. São Paulo apresenta uma média mais baixa, com 31 anos e o Rio de Janeiro a mais alta, com 35,8 anos. Tomando São Paulo para comparação entre as carreiras jurídicas, temos certa semelhança na idade típica para nomeação como delegado, com aquela obtida para promotores (29 anos) e juízes (32 anos), como mostra outro estudo conduzido por Bonelli (2002).

\section{TABELA 2: DISTRIBUIÇÃO DOS DELEGADOS SEGUNDO A FAIXA ETÁRIA,} POR ESTADO

$\begin{array}{lccccc}\text { ESTADO } & \text { ATÉ 29 ANOS } & \text { 30-39 ANOS } & \text { 40-49 ANOS } & +50 \text { ANOS } & \text { TOTAL } \\ \text { Amapá } & - & 51,5 & 24,2 & 24,3 & 33 \\ \text { Bahia } & 5,4 & 41,3 & 27,2 & 26,1 & 92 \\ \text { Distrito Federal } & 9,2 & 47,7 & 36,9 & 6,2 & 65 \\ \text { Goiás } & 11,9 & 18,6 & 39,0 & 30,5 & 59 \\ \text { Pernambuco } & 2,5 & 40,0 & 31,5 & 26,3 & 80 \\ \text { Paraná } & - & 31,1 & 39,2 & 29,7 & 74 \\ \text { Rio de Janeiro } & 13,4 & 29,5 & 23,2 & 34,0 & 112 \\ \text { Rio Grande do Sul } & 7,4 & 30,9 & 32,4 & 29,4 & 68 \\ \text { São Paulo } & 5,2 & 34,5 & 38,0 & 22,4 & 640 \\ \text { TOTAL } & 6,0 & 34,9 & 34,8 & 24,4 & 1.223\end{array}$

Fonte: Pesquisa Idesp, 2002, “Quem são e o que pensam os delegados de polícia”.

A renovação do quadro de delegados na ordem democrática foi intensa, com $62 \%$ das nomeações tendo ocorrido após a aprovação da 
Constituição de 1988. Essa porcentagem é maior nos estados do Rio de Janeiro, Amapá e Distrito Federal, ultrapassando 80\% (Tabela 3). Entre os estados com carreiras consolidadas há mais tempo, o Rio de Janeiro foi o que apresentou maior alteração na composição de seu corpo profissional.

\section{TABELA 3: DISTRIBUIÇÃO DOS DELEGADOS SEGUNDO O PERÍODO DE} NOMEAÇÃO, POR ESTADO

$\begin{array}{lcccccc} & \text { ANTES } & 1980- & 1985- & 1990- & \text { DEPOIS } & \text { TOTAL } \\ \text { ESTADO } & 1979 & 1984 & 1989 & 1994 & 1995 & \\ \text { Amapá } & 5,9 & 8,8 & 2,9 & 73,5 & 8,8 & 34 \\ \text { Bahia } & 4,5 & 18,2 & 13,6 & 4,5 & 59,1 & 88 \\ \text { Distrito Federal } & - & 3,1 & 13,8 & 20,0 & 63,1 & 65 \\ \text { Goiás } & 8,6 & 10,3 & 25,9 & 27,6 & 27,6 & 58 \\ \text { Pernambuco } & 8,8 & 6,3 & 30,0 & 3,8 & 51,3 & 80 \\ \text { Paraná } & 17,3 & 5,3 & 18,7 & 37,3 & 21,3 & 75 \\ \text { Rio Janeiro } & 8,0 & 9,8 & - & 38,4 & 43,8 & 112 \\ \text { Rio Grande do Sul } & 13,2 & 5,9 & 7,4 & 35,3 & 38,2 & 68 \\ \text { São Paulo } & 9,2 & 5,3 & 29,2 & 42,8 & 13,5 & 638 \\ \text { TOTAL } & 8,9 & 7,0 & 21,8 & 35,2 & 27,1 & 1.218\end{array}$

Fonte: Pesquisa Idesp, 2002, “Quem são e o que pensam os delegados de polícia”.

Períodos com modificações expressivas nos quadros ativos na carreira podem ser uma ocasião propícia para mudar as práticas e os valores que orientam o grupo profissional, principalmente quando coincidem com um contexto político que impulsiona novas condutas. Mas Monet (2001) não crê que seja possível modificar a atuação da polícia apenas a partir da mudança no ethos profissional. Para ele, são imprescindíveis tanto os controles burocráticos e disciplinares sobre a polícia como aqueles provenientes dos sistemas político e judiciário:

$\mathrm{Na}$ verdade, todas as avaliações demonstram que não há nenhum sistema de controle externo - hierárquico, administrativo, judiciário, público - que seja verdadeiramente satisfatório. A natureza do trabalho policial é tal que não pode ser controlado, a não ser do interior do sistema e no ponto mais próximo da ação, ou seja, no limite, no nível do policial que age por conta própria. Eis porque, nos diferentes países europeus, os esforços dos anos recentes procuram elaborar uma deontologia profissional e insistem na proteção dos direitos do homem. O esforço é louvável, mas lento para produzir seus frutos. É muito difícil, com efeito, inculcar no jovem policial hábitos opostos aos que lhe recomendam seus colegas antigos quando ele chega a um serviço (Monet, 2001, p.301).

Mesmo que a grande maioria dos delegados atuantes hoje não tenha partilhado das práticas predominantes no autoritarismo, o autor vê facilidade na reprodução das condutas dominantes então, devido ao padrão de socialização na carreira. Apesar da preocupação dos estudiosos, os delegados não se identificam nesse diagnóstico. Eles travam uma luta incessante pelo poder de nomear-se de outra forma e de dissociar sua imagem pública daquela ligada ao regime autoritário, enfatizando sua distância do mundo militar, seu treinamento jurídico nos princípios do Estado de Direito e o recrutamento após a redemocratização, na vigência da Constituição Federal de 1988.

A Revolução foi feita em 1964. A polícia civil não foi o órgão de repressão do governo autoritário. Em primeiro lugar porque o governo era militar, dirigido por militares, eles comandaram diretamente a polícia militar. Você pode verificar na história da PM que o general João Batista Figueiredo foi comandante da PM e atrás dele, outra sequência de generais e coronéis do Exército da ativa assumindo o controle como secretários da Segurança. A Polícia Civil continuou cumprindo seu papel normalmente, papel absolutamente democrático. Você não pode confundir a corporação com meia dúzia de delegados que trabalharam diretamente ligados ao regime militar e à repressão política. Em segundo lugar, o pessoal que participou da Revolução de 64 hoje ou já morreu ou realmente já está velhinho e aposentado. Hoje, 60\% dos novos delegados de polícia nasceram após 1964. Na Revolução de 64 não tinham nem sequer nascido. Hoje está havendo realmente uma penalização de toda a nossa estrutura policial em função disso, delegado de polícia é torturador. Não, delegado de polícia é bacharel em Direito, com formação jurídica, formação em Ciências Humanas, que hoje está pagando um preço altíssimo porque no órgão de repressão política, o DOI-Codi dirigido pelo Exército, e constituído pelo Exército, Marinha, Aeronáutica, Polícia Militar, Polícia Federal e Polícia Civil - todos os militares usavam codinome civil. Eram os doutores, dr. fulano, dr. José, dr. Paulo, e os civis eram obrigados a usar denominações de militar. Era o capitão fulano, tenente fulano, então houve uma confusão. A maioria do pessoal era militar que estava vestindo a 
carapuça de autoridade civil e o delegado de polícia encarado como doutor (delegado exercendo representação profissional)

Atribui-se à renovação de quadros orientada pelas práticas democráticas e pela formação jurídica a mudança de atitude da autoridade policial. Os delegados identificam na Constituição Federal de 1988 o nascimento da Polícia Civil de carreira no âmbito nacional, baseada na exigência da habilitação em Direito e no concurso público. As garantias de carreira de que gozam os juízes e os promotores foram decisivas para consolidar a lógica do profissionalismo nesses grupos. Elas reduzem a dependência diante do poder político, quando coíbem as nomeações sem concurso público, as manipulações de cargos comissionados, as demissões e as remoções não previstas na carreira. Entretanto, no cotidiano das delegacias, o insulamento institucional é limitado. Além disso, o recrutamento endógeno é significativo. Ao analisar-se a composição da amostra quanto à sua procedência ocupacional ligada à segurança pública e áreas afins e a existência de parentes na polícia, depara-se com um cenário menos renovado. Tais padrões reforçam as preocupações com a reprodução das condutas e do ideário dominante na polícia antes das mudanças constitucionais.

No total da amostra, 39\% dos delegados exerciam atividades na segurança pública, na defesa nacional ${ }^{3}$ ou nas posições intermediárias e inferiores do sistema de justiça antes de ingressar na carreira. Destacam-se os escrivães de polícia $(14 \%)$ e investigadores de polícia (10\%). A advocacia também ocupou parte dos delegados antes da nomeação. Ela foi mencionada como a última atividade profissional por $25 \%$ dos entrevistados. O Distrito Federal e o Rio de Janeiro apresentaram um perfil mais endógeno, com uma percentagem superior a $45 \%$ dos entrevistados trabalhando na Polícia Civil antes da nomeação no cargo. A recente proibição de desempenho da função de delegado sem diploma de bacharel em Direito e sem ingresso na carreira por concurso público elevou a participação dos delegados que vieram das profissões jurídicas, na Bahia, atingindo 39\%. Reunindo-se os aspectos demográficos da amostra, esse estado apresenta a maior renovação, com um grupo profissional relativamente jovem, nomeado recentemente, com expressiva participação feminina, proveniente da advocacia, menos endógeno e com baixa

\footnotetext{
${ }^{3}$ Inclui basicamente as Forças Armadas, em especial o Exército.
}

incidência de parentes na Polícia Civil se comparado aos outros estados pesquisados. A ênfase na função social e comunitária da polícia favorece a nova composição por gênero.

\section{Segundo Maria Cândida Bahia (2002):}

A análise do estilo de gestão das mulheres delegadas de polícia de Salvador, caracterizado como "gestão feminina", revelou o papel social da Polícia, até então enfatizada por sua função repressiva. A Delegacia é um departamento do Estado que, entre outras funções, presta serviços à população, geralmente carente, que recorre ao socorro policial - vítima de violência física, moral, étnica, sexual etc. Este trabalho irá mostrar que o aspecto social da Polícia tem sido destacado pela atuação feminina. Carregando para o público um pouco do apreendido no mundo privado - em que são enfatizados valores da solidariedade, compreensão - a mulher parece estar modificando a forma truculenta que tem marcado o aparato repressivo policial do Estado. Mais uma vez está a mulher cumprindo "seu papel", tradicional, voltado para o social, assistencial e filantrópico (Bahia, 2002, p.17)

A atuação da mulher delegada, num cargo dominado por homens até então, está de acordo com a representação simbólica do mundo feminino. Sua diferença, que determina um "estilo" peculiar, é apontada, por ela própria e pelos outros, com base nos atributos que são tradicionalmente considerados femininos: sensível, solidária dedicada, leal, detalhista, cuida do ambiente físico, organizada, democrática, preocupada com o social (Bahia, 2002, p.150).

Embora essa autora enumere características da socialização no papel feminino a influenciar as práticas nas delegacias, ela também encontra várias referências sobre a reprodução dos valores dominantes na carreira, inclusive quanto à especialização das atribuições segundo o gênero: a função social e comunitária da polícia pertencendo mais ao domínio feminino e a repressiva ao masculino. Até os atributos do próprio "estilo feminino" de comandar incorpora às práticas a reprodução de estereótipos da diferenciação entre os gêneros. Assim, a função social da polícia que ganhou relevância com a redemocratização, introduzindo novas condutas para orientar a ação policial, passa a ser associada às mulheres. 
O que o estudo de Bahia (2002) permite inferir é como o ingresso feminino reflete-se na instituição. A convivência entre homens e mulheres na mesma carreira resulta em interações diferentes daquelas onde a morfologia do grupo é predominantemente de apenas um gênero. Alteramse tanto as práticas dos profissionais devido à convivência mútua como as atribuições institucionais perante os usuários. No caso da Polícia Civil baiana, a ênfase na função social adequa-se à feminização, compondo um quadro de práticas mais plurais para a organização, sendo assim percebido pelo público. A origem dessas mudanças não foi o aumento do contingente feminino, mas as regras do Estado de Direito que estabeleceram novas condutas profissionais para a Segurança Pública.

O conceito de reflexividade institucional elaborado pelo sociólogo inglês Anthony Giddens (1993) é próprio para a análise das modificações que ocorrem na atuação dos agentes e das autoridades policiais atualmente. Ele considera que nas sociedades democráticas contemporâneas as instituições não são apenas o locus da reprodução do poder e do controle social, elas ganham as características da estrutura social, que tanto constrange como impulsiona mudanças. Para ele, a capacidade reflexiva dos seres humanos também é encontrada nas instituições, formando a memória, o conhecimento e o processo de pensar sobre si mesma, além de refletir as condições sociais em que elas se inserem. As práticas adotadas pelos indivíduos e grupos transformam as instituições que não são imunes a essa reflexividade.

A possibilidade que levantamos é a de que um contexto com mudanças no exercício profissional, decorrentes de práticas mais democráticas e marcadas pela maior convivência entre os gêneros na Polícia Civil, resulte em novas atribuições institucionais. Não é a presença feminina em si que muda valores e a imagem pública. Isso decorre principalmente da ação política intencional de governos democráticos. Mas a interação entre delegados e delegadas gera novas práticas também para a instituição.

$\mathrm{O}$ ingresso de mulheres traz a novidade do casamento entre pares profissionais, já observado em outras carreiras. Tais relações de parentesco, entretanto, ainda são numericamente pequenas ( 32 casos) diante da quantidade de delegados que informou ter pai/mãe, filho/filha na polícia (164 casos). Esse tipo de laço familiar reforça o temor entre especialistas, que se reproduza o estilo mais tradicional de fazer polícia, inibindo mudanças na conduta profissional. Os estados com forte participação de delegados que declararam possuir parentes na instituição são Goiás, Paraná, Rio Grande do Sul e São Paulo, com montantes superiores a 40\%. Não é por acaso que o discurso das lideranças constrói a imagem da corporação como "a família policial".

O percentual mais baixo de delegados com laços familiares na polícia foi obtido para a Bahia, seguida do Rio de Janeiro. O grau de parentesco que os delegados informaram variou bastante, sendo reunidos em um grupo seguindo a proximidade, com o núcleo familiar de pais, filhos, irmãos e cônjuges; e a parentela, como avós, sogros, tios, primos, cunhados, genros e sobrinhos foi classificada em outro. Em Goiás, os dois blocos marcam igualmente a composição do grupo profissional, mas nos demais estados predominou a família nuclear. A exceção é o Amapá onde registramos mais casos de delegados com graus de parentesco periféricos.

A ocupação dos parentes na Polícia Civil foi classificada em cargos administrativos, cargos técnicos, policiais no escalão inferior e policiais superiores, incluindo todos os delegados nesta categoria. Novamente, foram os estados de Goiás, São Paulo, Paraná e Rio Grande do Sul que se destacaram, apresentando as maiores incidências de parentes no topo da corporação.

No total da amostra, 38\% declararam ter parentes na Polícia Civil. Por outro lado, quando perguntados sobre os fatores que influenciaram a decisão de ser delegado, $26 \%$ dos respondentes atribuíram importância ao parentesco intervindo na escolha da profissão.

Um exemplo desta influência pode ser observado no depoimento abaixo, no qual um delegado relata o apego de sua filha à profissão.

Eu só tenho uma filha. Quando ela fez 18 anos e entrou para a faculdade de Direito, fez concurso para escrivã e passou em primeiro lugar no interior. Ela ficou trabalhando [...] e fazendo a faculdade [...]. Estagiava com o Ministério Público fazendo a faculdade e sendo escrivã. Quando ela fez 19 anos, o primeiro presente que eu dei para ela [foi]: eu cheguei em casa com uma caixa grande, aí [estavam] as coleguinhas e tudo o mais [...]. Eu botei a caixa no meio da sala. Ela começou a tirar; tira uma caixa; tira outra, e acabou numa caixinha que tinha um revólver 38. Todas as amigas se assustaram: "Enquanto todos os pais escondiam as armas dos filhos, eu dava para minha 
filha um revólver 38?" Eu expliquei para todos: - Esse é o material de trabalho dela, talvez, queira Deus que não, mas um dia com essa arma, ela pode defender a vida de um dos senhores. Então isso é o material de trabalho dela: a máquina por ela ser escrivã e a arma que vai acompanhar ela. E acompanha ela até hoje. Aí acabou como escrivã, terminou a faculdade de Direito e já se inscreveu para ser delegada de polícia e passou em primeiro lugar no concurso de delegados de polícia com média 9,6. Me deu um susto. Eu não queria que ela fosse delegada. Para deixar ela mais ou menos assim $[\ldots]^{4}$ a única filha, a carreira para a mulher é complicada. Aí ela passou e me falou que queria ser delegada, eu era regional de polícia na região. Ela veio trabalhar na minha região. Eu botei ela no pior lugar, eu botei no plantão que atende todas as piores encrencas que você pode imaginar. No primeiro plantão que ela tirou, ela entrou às 9 horas da manhã de um sábado e saiu às 2 horas do domingo, ela tinha que acabar o plantão às 6,7 horas da noite, mas deu uma ocorrência, deu tiroteio, ela acabou prendendo em flagrante e foi terminar no domingo 2 da tarde, que ela veio embora. A mãe ficou na sala preocupada, e eu me lembro quando a minha filha entrou com o cabelinho todo suado, aí ela sentou. Eu perguntei o que foi e ela começou a contar. [Então] eu falei para minha mulher que ela nunca mais sairia da polícia. Ela acabou às 2 da tarde, cansada, mas feliz e tudo bem... Ela tem muito cheiro de polícia, ela gosta, na minha casa só se fala de polícia (delegado de classe especial).

A convivência com os valores da carreira no ambiente familiar despertou o gosto pela atividade policial, ilustrando o impacto da socialização primária, depois reforçado na interação da jovem no ambiente de trabalho da delegacia, como escrivã de polícia. A autoidentificação com a vida policial aparece como um processo natural, que resulta na confirmação desses elos com a escolha da profissão de delegada. Embora tal processo seja percebido como uma vocação natural ou um dom, ele é essencialmente social, formando-se a partir das experiências partilhadas no cotidiano.

Esse padrão é inevitável nas redes de sociabilidade que ligam as pessoas e os grupos com propósitos comuns. É devido a essa característica que Monet (2001) teme a reprodução dos valores tradicionais dominantes na polícia, levando-o a um prognóstico que aponta para a impossibilidade de

\footnotetext{
${ }^{4}$ Sentir se era mesmo aquela escolha profissional dela.
}

mudança partindo de dentro da corporação. O sociólogo francês Pierre Bourdieu (1999) tratou do problema da reprodução do status quo em várias dimensões da vida social nas quais predominam as relações de dominação, aspecto que não se limita à polícia, difundindo-se por todo o espaço social hierarquizado. Embora tais estruturas sejam recorrentes, o autor destacou possibilidades de mudança, em geral, associadas à ação política contrária à ortodoxia dominante no grupo. Segundo ele, o surgimento de interpretações dissonantes no interior do campo e de disputas para atribuir outros significados às ações que valorizam, impulsionam a heterodoxia que questiona a estrutura de dominação, criando chances de resistência. Tal modelo analítico aplica-se também à segurança pública. Além da ação política voltada para dar novo conteúdo às atribuições policiais na ordem democrática, há brechas capazes de gerar novas interpretações a respeito da prática, da conduta e dos valores profissionais, para questionar a ortodoxia predominante no grupo.

O problema da reprodução de estruturas de dominação também afeta os delegados de polícia no que diz respeito ao lugar que ocupam na fronteira entre os campos da segurança pública e da justiça. A atividade que eles desenvolvem insere-se na área da segurança pública onde também atua a Polícia Militar. A formação jurídica do delegado é um dos fatores da forte diferenciação com os oficiais da PM. As rivalidades entre estas duas corporações são históricas (Holloway, 1997; Souza, 1998) e podem ser percebidas nos trechos abaixo, extraídos de comentários espontâneos escritos por delegados nos questionários da pesquisa.

A Polícia Civil vem sendo encurralada. [...] Os policiais militares constantemente vêm imiscuindo-a com as funções próprias da Polícia Civil. [...] A Polícia Militar vem mostrando-se ineficiente na prevenção dos delitos, contudo, quando a segurança pública mostra-se preocupante, as atenções são voltadas para a Polícia Civil e cobram-se explicações e providências (Delegado do Rio Grande do Sul).

A PM deveria ser extinta, pois é resquício da ditadura. É o braço armado do governo truculento e incompetente, além do mais, corrupto (Delegado do Paraná).

Por outro lado, a autoidentificação como bacharel é enfaticamente apresentada como instrumento na luta concorrencial com outros profissionais do Direito para garantir sua posição no campo jurídico, 
reconhecimento muitas vezes negado por promotores de justiça. Essa posição dominada, no que diz respeito ao capital social que reuniram na trajetória entre a origem familiar, o casamento e a experiência no mercado de trabalho, é reafirmada pela posse restrita de capital cultural, confirmada pela faculdade cursada e pelos concursos realizados perante as demais carreiras jurídicas públicas, perpetuando a reprodução do lugar que o grupo ocupa nesse campo.

As características exploradas na pesquisa que indicam a origem social dos delegados foram o grau de instrução do pai e da mãe, o número de irmãos e os irmãos com curso superior, a ocupação paterna e a materna. Como indicativo de laços sociais estabelecidos por meio do matrimônio e o tamanho das famílias focalizamos o número de filhos, a escolaridade e a ocupação do cônjuge.

Para o grau de instrução paterna, há uma divisão, com cerca de metade do total da amostra tendo, pelo menos, o segundo grau completo, e a outra parte ficando abaixo desse nível de escolaridade. O valor modal é de $29 \%$ dos pais com curso superior completo. São os delegados do Rio de Janeiro e de São Paulo que apresentam uma origem social mais instruída, ultrapassando os $30 \%$ de pais com diploma de terceiro grau. No outro extremo estão Amapá, Paraná e Goiás, com mais de $40 \%$ de pais sem instrução ou com primário incompleto.

Quanto ao grau de instrução materno, o Rio de Janeiro se destaca com quase $25 \%$ das mães tendo curso superior completo. $\mathrm{Na}$ base da pirâmide de escolaridade, Amapá e Goiás chegam quase a atingir 50\% de mães sem instrução ou com primário incompleto. $\mathrm{O}$ valor modal para o total da amostra é o segundo grau completo, com $25 \%$.

No que se refere ao número de irmãos, os delegados do Amapá e do Distrito Federal têm origem nas maiores famílias, com mais de $75 \%$ da amostra possuindo de três a dez irmãos. No Rio de Janeiro está a maior percentagem de famílias pequenas, tendo $65 \%$ dos delegados até dois irmãos (10\% dos delegados é filho único). Calculada a média da proporção de irmãos com curso superior, obteve-se em todos os estados valores inferiores a um, o que destaca maior titulação do delegado em relação a seus irmãos, apontando para uma ascensão devido ao maior número de anos de estudo. São Paulo foi o único estado que ultrapassou a média obtida para toda a amostra (0,60 irmão com curso superior), com um perfil fraterno um pouco mais escolarizado $(0,65)$. No Amapá e no Rio Grande do Sul essa média foi inferior a 0,50 , sendo estados onde a obtenção do diploma de bacharel em Direito representou um diferencial em escolaridade e consequentemente em mobilidade intrageracional ascendente para os delegados.

A origem social também pode ser dimensionada pela principal ocupação dos pais. No total do grupo pesquisado, há predomínio dos estratos médios, acentuadamente nas ocupações burocráticas de nível médio (13\%) e nos pequenos e médios proprietários urbanos (11\%). Se agruparmos as profissões do Direito, as posições de nível superior na segurança pública e as ocupações da segurança e da justiça de nível médio têm-se uma dimensão do impacto deste campo na carreira do filho. No Rio de Janeiro e em São Paulo, obtiveram-se valores próximos a $25 \%$ dos pais dos delegados nessas atividades. Nesse aspecto, os delegados cariocas e paulistas diferenciam-se dos demais, revelando um perfil mais familiar às áreas da justiça e da segurança pública. Em Goiás, o valor modal para a ocupação paterna foi a dos pequenos e médios proprietários rurais, seguido das ocupações burocráticas de nível médio.

A principal ocupação da mãe é a atividade do lar, ultrapassando $60 \%$ das respostas, seguida das atividades de magistério e professoras de segundo grau $(15 \%)$. No Distrito Federal, os delegados filhos de mulheres ocupadas nas tarefas da casa e da família chegaram a 75\% e na Bahia, onde há o maior contingente de delegadas, essa proporção foi a menor da amostra $(58 \%)$.

A origem de classe média tradicional dos delegados de polícia salta aos olhos. Em termos de capital social e cultural, Rio de Janeiro e São Paulo teriam um pouco mais de cacife para impulsionar o lugar da profissão se comparados aos demais estados. Já no contexto local onde eles atuam, a morfologia social das profissões concorrentes no mundo do Direito anula essa pequena vantagem.

Quanto ao matrimônio, há na amostra quase $17 \%$ de solteiros, que estão concentrados nos estados que reúnem mais delegadas, como a Bahia e o Rio de Janeiro ( $28 \%$ em ambos os estados). As famílias constituídas pelos delegados possuem características distintas daquelas das quais provieram devido às mudanças decorrentes da modernização. $O$ tamanho do núcleo familiar encolheu. Daqueles que têm filhos, apenas $25 \%$ tiveram de três a 
sete filhos, sendo dois filhos o valor modal com $36 \%$ dos casos. Esse padrão é semelhante em todos os estados. A escolaridade do cônjuge aumentou se comparada à da geração dos pais, havendo $60 \%$ com curso superior completo. Os estados que ultrapassaram um pouco esse patamar foram Distrito Federal, Bahia, Goiás e São Paulo. O Amapá e o Rio Grande do Sul ficaram bem abaixo desse percentual, revelando um modelo menos homogêneo de união conjugal.

Apesar do avanço no grau de instrução de maridos e mulheres, a mobilidade social da família do delegado parece decorrer principalmente da ocupação do informante, embora a contribuição do cônjuge em ocupações economicamente ativas seja bem mais significativa do que na geração da mãe. Apenas 18\% dos informantes declaram que o cônjuge não era economicamente ativo. Nos estados do Paraná, do Rio Grande do Sul e Amapá, a percentagem dessas respostas ultrapassou $23 \%$. As atividades ocupacionais predominantes entre eles(as) são as profissões de nível superior (20\%), as ocupações burocráticas de nível médio (12\%), o magistério e o ensino médio (12\%).

\section{OS DELEGADOS DE POLÍCIA NO CAMPO JURÍDICO}

Os dados apresentados acima apontam uma trajetória de ascensão social do delegado em relação à sua família de origem. Entretanto, o valor de tal percurso social perde relevância quando a referência deixa de ser os pais e passa a ser os competidores no mundo do Direito. Os indicadores utilizados para aferir que características do grupo fragilizam seu capital social e cultural nas lutas concorrenciais do campo foram a faculdade cursada, o número de anos gastos para concluí-la e os concursos realizados. Como mostra a análise de Dantas, em artigo neste volume, há uma diferença substantiva entre as escolas cursadas pelos delegados de polícia e aquelas onde juízes e promotores formaram-se, alimentando as disputas classificatórias no mundo do Direito. Predominam entre os delegados a formação em faculdades privadas menos seletivas para aprovação. No caso dos profissionais aprovados nos concursos públicos para a Magistratura e o Ministério Público, destacam-se os cursos mais competitivos para o ingresso e mais bem avaliados pelo Ministério da Educação. Outros dados que Dantas apresenta ajudam a qualificar essa divisão entre as carreiras. Em primeiro lugar, há um contingente significativo de delegados de polícia formados em cursos com boa avaliação pelo MEC (43\% deles estudaram em faculdades com conceito "A" ou "B"). Entretanto, esse bom desempenho acadêmico não qualifica o grupo o suficiente para conter a depreciação de sua imagem nas lutas internas ao campo jurídico. Os $25 \%$ dos delegados que estudaram nas faculdades avaliadas com "D" e "E" estigmatizam o conjunto da profissão. Embora o MP nos estados reúna 12\% de promotores formados no mesmo tipo de escola, a instituição não se contagia por tal resultado como ocorre na Polícia Civil.

Verifica-se, portanto, um padrão semelhante ao descrito por Elias e Scotson (2000), em Os Estabelecidos e os Outsiders. Trata-se de um estudo sobre as relações de poder em uma pequena comunidade, na Inglaterra, do final dos anos de 1950, organizada em três zonas residenciais. A primeira apresentava condições típicas de um bairro de classe média. As outras duas zonas tinham características objetivas muito semelhantes quanto à posição social de seus moradores, com predomínio de operários. Apesar das semelhanças, os moradores das duas últimas zonas construíram uma estrutura de relações de vizinhança na qual os residentes mais antigos detinham poder sobre aqueles que haviam migrado para a comunidade após a Segunda Guerra Mundial. Os estabelecidos ocupavam a zona dois denominada de aldeia, formada por "centenas de meias-águas contíguas, com muitas vielas estreitas e pequenos quintais" (Elias e Scotson, 2000, p.74) e os outsiders viviam na zona três, uma área de loteamento construída posteriormente. Entre os estabelecidos, a "minoria dos melhores" dava identidade e distinção a todos os membros do grupo dominante, revelando a força e o carisma grupal. Entre os outsiders, as características depreciativas da "minoria dos piores" transformavam-se na desonra grupal. A desunião no loteamento favorecia a estigmatização e dificultava o revide. A concordância, mesmo a contragosto, com a opinião dos moradores da aldeia sobre o loteamento contagiava o valor social do grupo, forçando a aceitação do status inferior.

Assim, as calúnias que acionam os sentimentos de vergonha ou culpa do próprio grupo socialmente inferior, diante de símbolos de inferioridade e sinais do caráter imprestável que lhes é atribuído, bem como a paralisia da capacidade de revide que costuma acompanhálos, fazem parte do aparato social com que os grupos socialmente dominantes e superiores mantêm sua dominação e superioridade em 
relação aos socialmente inferiores. Há sempre uma suposição de que cada membro do grupo inferior está marcado pela mesma mácula. Eles não conseguem escapar individualmente da estigmatização grupal, assim como não conseguem escapar individualmente do status inferior de seu grupo (Elias e Scotson, 2000, p.131).

Há semelhança entre a posição dos delegados de polícia no campo jurídico e os outsiders no estudo de Elias e Scotson. Embora nas classificações objetivas dos estratos ocupacionais, as carreiras públicas na área do Direito sejam identificadas como semelhantes e pertençam ao mesmo grupo, no interior do campo a situação é distinta. Por vários anos essas carreiras tiveram isonomia salarial, que foi perdida pelos delegados de polícia em vários estados. A relação de dominação que se estabelece entre eles é baseada em recursos de excelência. Os dominantes são os profissionais com acúmulo de capital social e cultural, que construíram o poder e a autonomia de instituições como a Magistratura e mais recentemente o Ministério Público. As principais lutas concorrenciais se dão entre os promotores e os delegados de polícia. Estes últimos, incapazes de alterar a relação de dominação, ressentem-se da estigmatização de que são vítimas, de serem mal preparados para a função devido à formação acadêmica de baixa qualidade. A acusação dos promotores encontra evidências empíricas, mas a diferenciação subjetiva parece maior do que a objetiva. Criticar os delegados é um fator de coesão para os promotores e de construção de seu carisma grupal. A reafirmação de sua posição superior foi legitimada pela preservação da isonomia salarial com os juízes, equivalência rompida com os delegados. Esse resultado ajuda a apagar os vestígios de que há $12 \%$ de promotores de justiça dos estados provenientes de cursos com conceito " $D$ " e "E", dignificando todos os membros da carreira como donos de sólido saber jurídico. Entre os delegados, o demérito da má formação em Direito contagia o grupo como um todo, mesmo que o montante dos que frequentaram esses cursos não ultrapasse a um quarto. Se o ataque unifica os promotores, a acusação divide os delegados, tornando difícil revidá-la. Eles retaliam os promotores em outros aspectos, mas nesse veem-se obrigados a aceitar o status inferior.

No que diz respeito ao despreparo acadêmico dos delegados, há, entre eles, uma forte incorporação da opinião de que isto é um problema para a corporação. Perguntados sobre a importância que a formação deficiente dos delegados tinha como fator de obstáculo ao bom funcionamento da Polícia Civil, 51\% dos entrevistados consideraram muito importante e $38 \%$ consideraram importante.

Quanto ao revide, alguns delegados procuraram caracterizar promotores e juízes como "almofadinhas", que começam a trabalhar depois de uma hora da tarde, não aguentando uma vida de "tirar plantão", de trabalhar sábado e domingo, tendo de tomar decisões no calor dos acontecimentos, sem tempo para reflexão e sem acesso aos promotores depois de encerrado o expediente. Em contraste, a valorização do delegado vem da habilidade técnico-jurídica e do preparo moral e emocional para lidar com as situações imprevistas que envolvem o flagrante, a diligência, a ocorrência e a preparação do inquérito.

Chega uma ocorrência pesada para você, uma troca de tiro na rua, um policial que matou o outro, alguém morreu [...]. Ninguém vai conseguir saber, a não ser o delegado de polícia, a transcrever o peso de uma ocorrência... Parece que resolver aquilo ali é fácil. É complicado transformar tudo aquilo em papel. Eu tenho quase que certeza absoluta que nenhuma outra carreira jurídica, sem demérito, ninguém faz tão benfeito como faz um delegado de polícia quando ele transcreve um crime, quando ele faz um flagrante. É dele, são passos e passos que só ele sabe dar, como fazer uma técnica, como fazer uma peritagem, como perguntar, como provar, porque, veja você, é a única carreira jurídica que decide no calor. O próximo calor é o júri, apesar de que é um calor programado. O nosso é uma fogueira de pau, o outro lá é elétrico, você programa. Chega a falar com você uma pessoa que não é ele que é a vítima, ele é que matou o outro, e você não tem tempo. Você tem um prazo para fazer aquilo, você tem que acreditar e fazer. Não é só dizer que acredita naquilo, você tem que transformar aquilo em verdade e em papel. É muito difícil, e sem se emocionar... Às vezes é obrigado a prender uma pessoa que, de certa forma, é inocente, matou o outro em legítima defesa. Eu sou obrigado a fazer o flagrante nele, que só cabe ao juiz, na realidade, provar praticamente que não foi ele.

[...] Acabar com o inquérito policial é falta de patriotismo. "Vamos tomar dos delegados de polícia o inquérito policial". Então, esse é um país de maravilha. Nós temos o juiz que é bacharel de Direito, o promotor é bacharel de Direito e o delegado que é bacharel de Direito. Os três fizeram a mesma faculdade, fizeram o curso diferente. Você 
tem hoje um juiz que está sentado em uma situação, decidindo com todo o garbo dele, sem envolvimento. O promotor que é garrido, que é isso que faz. Só um bacharel de Direito vai para rua, pisa no barro, corre, vai atrás. Nós temos hoje um cara que é esclarecido, que se chama delegado de polícia, que administra essa encrenca na rua e que é bacharel de Direito como o promotor e o juiz. Se ele não fosse um cara preparado a esse nível, nós teríamos muito mais violência acontecendo. São anos de cadeira, onde você educa na escola [...]. Se você acaba com a figura dele, põe quem? Aquele que não sai para rua, que só fica no gabinete e fica só escutando o que estão fazendo lá fora? Ou aquele que não é bacharel, que eu acho pior... Nós, de certa forma, incomodamos. Tem muita gente que tem vontade de ter o poder discricionário da polícia; a rapadura é doce mas é dura. Não é muito fácil ser delegado... (Delegado de classe especial).

O segundo aspecto apresentado no artigo de Dantas, que diferencia as carreiras e a formação acadêmica obtida nas faculdades, é como o conteúdo valorizado nos cursos de Direito de elevada avaliação não contempla adequadamente o Direito Penal, por ser mais desprestigiado como conhecimento técnico-jurídico. Todo o universo que circunda o mundo do crime recebe a mesma depreciação social, seja a especialização criminal, os profissionais que trabalham com ela e os grupos sociais envolvidos. Assim, se entre as escolas de elite a temática não é bem valorizada, os profissionais que atuam na segurança pública desenvolvem suas redes que conectam o mercado de trabalho e as faculdades privadas. "Tiras" ingressam nessas escolas para tentar o concurso para delegado de polícia, tendo por professores membros da carreira cobiçada. É principalmente nos cursos com conceitos mais baixos que a disciplina Direito Penal é mais reconhecida como sendo bem ministrada.

Outro fator utilizado no campo jurídico para depreciar a formação acadêmica dos delegados é o tempo consumido por eles para terminar a faculdade. O curso de Direito é organizado para ser concluído em cinco anos, o que ocorreu com $50 \%$ dos entrevistados. A outra metade não se bacharelou no período regular: $32 \%$ levaram seis anos ou mais para obter o diploma e $18 \%$ conseguiram terminar o curso mais rápido. É no Rio Grande do Sul que os delegados consumiram mais tempo para se formar, com $69 \%$ precisando de pelo menos seis anos. Nos estados onde há maior porcentagem de delegadas, como a Bahia e o Amapá, mais de 60\% dos informantes conseguiram bacharelar-se em cinco anos.

Como há intensa pressão em rotular os delegados como mal preparados academicamente, a feminização da carreira pode ter uma consequência contrária à que normalmente lhe é atribuída, que é a de indicar a desvalorização da função. Nesse caso, ela pode ter resultados não antecipados, inclusive em relação ao capital social e cultural para fortalecer a carreira, já que a origem familiar das mulheres profissionais tende a ser mais elevada, por virem de famílias que puderam investir na educação delas. Os indicadores de desempenho escolar mostram que as meninas se saem melhor nos estudos do que os meninos, nas diversas classes sociais. Assim, uma maior participação de mulheres na carreira pode ter reflexos no padrão das faculdades onde o grupo profissional se gradua, reduzindo a incidência de diplomas obtidos em cursos com conceitos baixos e fora do perfil regular de tempo para sua conclusão.

\section{INFORMAÇÕES E OPINIÕES SOBRE A CARREIRA}

Em média, cada delegado realizou 2,12 concursos na sua vida profissional, sendo esse número maior no Distrito Federal $(2,84)$ e menor na Bahia (1,70). Como esses concursos eram para diferentes atividades (burocráticas, profissionais e técnicas), e diversas organizações (bancos, autarquias, administração direta, segurança pública, justiça), elas foram agrupadas para análise. Além dos concursos para a segurança pública de nível superior, prestados para ingresso na carreira de delegado, houve 60\% de concursos para cargos de polícia de nível médio (investigador e escrivão de polícia) e $54 \%$ de concursos públicos para as carreiras jurídicas (Magistratura, Ministério Público, Defensoria, Procuradorias etc.).

A farta experiência dos delegados na ordem burocrática e sua busca pela inserção no setor público chama a atenção. Para vários deles, o universo do trabalho paterno vinha marcado por essa lógica, já que $28 \%$ dos pais tiveram as ocupações burocráticas de nível médio ou as ocupações da segurança pública e da justiça como principal atividade no mercado de trabalho. Somada a essa familiaridade na forma de se estabelecer as

${ }^{5}$ O total é superior a $100 \%$ porque há uma média de dois concursos por entrevistado. 
relações de trabalho, $38 \%$ dos delegados estavam ligados às ocupações da segurança pública, defesa nacional e justiça antes da nomeação no cargo e outros $10 \%$ exerciam ocupações burocráticas de nível médio. A parentela na Polícia Civil (informada por 38\% dos entrevistados) partilhava conjuntamente a visão de mundo própria do "tira" inserido na hierarquia da Secretaria de Segurança Pública. Apesar desses números que indicam os laços anteriores com o mundo da polícia, os entrevistados não atribuíram tanta importância a tal interação na sua decisão de tornar-se delegado. A experiência anterior na polícia foi mais relevante do que ter parentes na segurança pública: $43 \%$ consideraram importante ou muito importante a primeira e $26 \%$ a segunda.

Os fatores apresentados como mais importantes na tomada de decisão para ser delegado estão relacionados às características altruístas como a defesa do cidadão (93\% acham muito importante ou importante) e a oportunidade de prestar serviços à comunidade (85\% acham muito importante ou importante). A estabilidade do emprego público segue sendo atraente, com $80 \%$ atribuindo-lhe importância, seguida da remuneração, com $70 \%$. Embora a carreira tenha perdido status, seu prestígio e reconhecimento continuam importante para $49 \%$ dos respondentes, ultrapassando a influência dos parentes e da experiência anterior na polícia. As alternativas que menos interferiram nesse processo de escolha foram a falta de opção no mercado de trabalho, apontada por $12 \%$ como muito importante ou importante e a influência de professores na faculdade, valorado apenas por $10 \%$ dos entrevistados.

A remuneração auferida pelos delegados varia segundo os estados. Enquanto em São Paulo o salário inicial é de R\$ 1.680,00, no Distrito Federal atualmente é de R \$ 6.800,00; no Rio de Janeiro e no Rio Grande do Sul aproxima-se dos R \$4.000,00. Com exceção do Distrito Federal, onde a União segue responsável pela remuneração da carreira, nos demais essa competência é do governo do estado. Os delegados do Distrito Federal ganharam recentemente na justiça algumas ações para elevar o piso salarial, o que também explica a diferença. Assim, entre eles, 55\% declararam receber um salário bruto superior a $\mathrm{R} \$ 7.500,00$. O Paraná é outro estado que remunera bem seus delegados: $85 \%$ deles ganham mais de $\mathrm{R} \$ 6.000,00$. No extremo oposto está a carreira mais feminizada do Brasil. O grupo que está mais mal remunerado é o da Bahia, com mais de $90 \%$ dos delegados recebendo menos de R \$3.000,00. Os estados de Pernambuco e São Paulo aproximam-se em remuneração à situação baiana, com $50 \%$ dos delegados pernambucanos e $30 \%$ dos paulistas inserindo-se na faixa de salário bruto entre $\mathrm{R} \$ 1.500,00$ e $\mathrm{R} \$ 3.000,00$. Para o total da amostra, $60 \%$ dos delegados percebem menos de $\mathrm{R} \$ 4.500,00$ mensais na Polícia Civil. O salário continua sendo um fator de atração para os delegados, mas ele é mais importante em alguns estados do que em outros, e também possibilita condições de vida e poderes aquisitivos diferentes se o delegado residir no interior ou na capital. Assim, em São Paulo, apenas $11 \%$ consideraram a remuneração muito importante na decisão de ser delegado enquanto no Distrito Federal 48\% dos entrevistados deram essa resposta. A distribuição da amostra quanto ao local onde exerciam a carreira nos nove estados pesquisados foi de 50\% nas capitais, $10 \%$ nas regiões metropolitanas e $40 \%$ nos municípios do interior.

A classe que os entrevistados ocupavam na carreira é outro aspecto que distancia o grupo profissional do piso salarial. O número de classes existentes varia por estado, mas predomina o padrão de ingresso na terceira classe, progredindo para a segunda, a primeira e a especial. Estados como o Paraná e o Rio Grande do Sul iniciam a carreira na quarta classe. São Paulo possui mais um degrau (quinta classe). Pernambuco foi o único estado que apresentou metade dos delegados na classe inicial da carreira, o que indica o tamanho da mudança recente na composição do grupo. Em São Paulo, apesar de haver $30 \%$ de delegados na faixa salarial considerada baixa em comparação aos demais estados, há poucos delegados na quinta classe (7,5\%), distribuindo o problema salarial por outras classes da carreira.

As discrepâncias salariais na comparação entre os estados e entre as carreiras jurídicas públicas são acionadas na justificativa para o exercício de outra atividade ocupacional. Excluindo a docência, o regulamento dessas carreiras públicas exige dedicação exclusiva, proibindo o acúmulo de ocupações ou "bicos" . Na amostra, 19\% dos delegados responderam afirmativamente à pergunta sobre possuir outra atividade. Inicialmente, achamos que não conseguiríamos obter respostas para esse tipo de

${ }^{6}$ Não foi possível distinguir o exercício da atividade docente regular, que é desempenhada nas faculdades e na Academia de Polícia, daquela típica do "bico", que é praticada na área de segurança privada. 
pergunta, devido à proibição legal. Por essa razão, a percentagem alcançada provavelmente não reflete a proporção efetiva de "bicos", mas foi superior ao esperado.

As oportunidades de desempenho de outra atividade variam de acordo com as características da região onde o delegado atua. Regiões urbanas, com problemas de violência, oferecem um mercado maior para consultoria e assessoria na área da segurança privada. Regiões rurais favorecem as atividades agropecuárias. A atividade mais declarada foi a de instrutor/professor na área de segurança privada, nos cursos de Direito e nas Academias de Polícia, seguida das atividades agropecuárias, da consultoria jurídica e em segurança, de atividades de comerciante e empresário, e dos cargos políticos eletivos. O Distrito Federal, onde há melhor remuneração, apresentou menor porcentagem de delegados exercendo outra atividade ocupacional, com apenas $8 \%$ de respostas afirmativas.

A ideologia do profissionalismo prioriza a realização de um bom trabalho em vez do ganho material, e de sua qualidade em vez de sua eficácia econômica. O modelo é apoiado pela valorização da dedicação integral à carreira, que justifica os privilégios do monopólio do mercado, elimina a concorrência e preserva a remuneração em um patamar digno. Em retorno, por meio da dedicação, o profissional persegue o avanço técnicocientífico e a prestação de um serviço especializado de qualidade para seus clientes e a sociedade. A realização de "bicos" e outras atividades ocupacionais compromete esse ideário, tanto nas relações com os pares como na imagem pública da carreira. A profissão fica fragilizada ideologicamente. Mas esse não é o único aspecto em que a carreira encontra dificuldades de ajustar-se ao profissionalismo. A burocratização e politização são dois outros aspectos que afastam os delegados do modelo profissional. Ter parentes na polícia e a experiência anterior na mesma organização são aspectos que podem realimentar a sociabilidade dos delegados com os valores burocráticos, e amortecer as indignações comuns entre os profissionais quando sua autonomia e seu ideário são ameaçados. A opinião do grupo sobre a ingerência política é ambígua. Embora haja uma coesão dos entrevistados criticando a interferência na cúpula da instituição, como obstáculo ao bom funcionamento da Polícia Civil, a prática partilhada não viabiliza o insulamento institucional.
As associações de delegados de polícia exercem papel ativo na articulação de candidaturas para representar seus interesses nas diversas instâncias legislativas e executivas, como as câmaras municipais, prefeituras, as assembleias estaduais e o Congresso Nacional, coordenando campanhas eleitorais, destacando colegas para concorrer a eleições, criando vínculos do grupo profissional com seus candidatos corporativos, além de dedicarem-se ao lobby junto aos parlamentares para aprovação de projetos específicos. Entre os delegados que responderam ao questionário, encontramos dez vereadores, um prefeito e um vice-prefeito. Eles estavam suficientemente ativos e comprometidos com a carreira para serem incluídos na amostra aleatoriamente, e declararem o cargo político como “outra atividade ocupacional". A fronteira entre profissão e política está pouco delineada se vista de dentro para fora, tal como de fora para dentro. O problema do insulamento não é só da parte do governo para com a instituição, mas também dos delegados para com sua profissão.

Apesar de haver três características da carreira que distanciam os delegados do modelo do profissionalismo - os "bicos", a politização e a subordinação ao comando do governo - eles possuem um ethos partilhado que dá identidade profissional e coesão ao grupo em torno da imagem do bom delegado. $\mathrm{O}$ conhecimento técnico e o saber jurídico são decisivos para essa autopercepção, reforçando o pertencimento ao mundo profissional do Direito. A proporção de respostas que consideram o saber jurídico e a preparação de inquéritos bem circunstanciados muito importante para ser bom delegado foi superior a $80 \%$; reunindo-se as respostas "importante" tem-se um consenso no grupo, com 99,5\%. Já o que gera mais discordância é a importância de ser reconhecido pelos pares $(31 \%$ acham muito importante) e a obediência aos direitos humanos (58\% acham muito importante). O reconhecimento pelos pares é um dos atributos distintivos das profissões que se orientam pela autonomia profissional, controlando-se e avaliando-se internamente. Outras questões que obtiveram adesão acima de $70 \%$ como muito importante para ser bom delegado foram: competência para trabalho de investigação, saber trabalhar em equipe, habilidade em lidar com situações de risco, e aptidão para chefia e liderança.

A passagem abaixo, extraída do depoimento de um delegado, permite identificar a dimensão altruísta do ideário do grupo, que é comum ao universo dos profissionais. A crença na profissão como missão e vocação 
aparece entre médicos, enfermeiros, professores, advogados, juízes, engenheiros, assistentes sociais, físicos e tantas outras, mas não diferencia as profissões mais poderosas das ocupações menos profissionalizadas. São as cinco características destacadas por Freidson (2001) e resumidas no início deste capítulo que demarcam esse terreno. Entretanto, para o grupo sua crença é vital, dando-lhe motivação para construir as possibilidades de confraternização e coesão.

Ser delegado é um negócio que está no sangue da pessoa, não adianta você querer fazer, a pessoa vem, o salário não é lá essas coisas, o sujeito vem e faz porque quer. Sai para a rua, toma tiro e no outro dia continua. Chora porque o comparsa dele morreu. No outro dia ele está com outro amigo, está indo atrás de uma certa forma. Nós temos situações de entrar em favela, de tomar tiro de fuzil na cabeça, o colega está caindo, a pessoa vai em cima, esse rapaz sara e continua. É como se fosse uma religião. Eu acho que ser policial é como se fosse uma seita. O sujeito que entra para a polícia gosta daquilo, adora a situação de ser policial, adora fazer parte do bem na luta contra o mal. Ele fica do lado do bem lutando, lutando, às vezes é interpretado pela sociedade como mal. Existem os maus policiais que a gente, de uma certa forma, elimina [...] (Delegado de classe especial).

Em resumo, a grande pergunta que o perfil social e de carreira dos delegados de polícia coloca para discussão é se, entre eles, predomina a reprodução das práticas vigentes no campo ou a mudança possibilitada pelo processo de a instituição refletir sobre si mesma, junto com as novas formas de ação de seus profissionais? Fortalecendo o diagnóstico da preservação das relações de dominação estabelecidas e das condutas tradicionais na segurança pública temos as evidências do baixo insulamento institucional, da politização, da frouxa distinção entre o modelo burocrático e o profissional, do impacto do recrutamento endógeno e de suas consequências para preservar práticas antigas. A favor da perspectiva da mudança tem-se a ação política intencional na ordem democrática estabelecendo novas condutas, a renovação do quadro profissional, que ampliou a convivência com práticas mais pluralistas, dando lugar a uma heterodoxia no campo que contesta a ortodoxia dominante. Há um expressivo número de delegados identificados com o profissionalismo e com a necessidade de insular a carreira; entretanto, eles não conseguiram coibir as práticas internas que a politizam, e muito menos regulamentar vedações.
A ausência dessas características tem custos para o grupo profissional. $\mathrm{O}$ fato de o poder de polícia ser um poder político não decorre que ele tenha de ser politizado (Reiner, 2000). Visto de outro ângulo, parece predominar entre os governantes a preferência por uma polícia sob seu comando direto. $\mathrm{O}$ temor da independência da carreira adquire o significado de perda de controle sobre ela, situação homóloga à que ocorria com os juízes de paz na época áurea da descentralização política do período regencial, no Império, quando a autonomia levava à resistência e à oposição armada.

\section{Referências Bibliográficas}

Bahia, Maria Cândida dos Anjos (2002). Mulheres no Comando das Organizações: Um Caso de Polícia. Dissertação de mestrado, Salvador, Universidade Federal da Bahia, Núcleo de Pós-Graduação em Administração.

BONELLI, Maria da Gloria (2002). Profissionalismo e Política no Mundo do Direito: As Relações dos Advogados, Desembargadores, Procuradores de Justiça e Delegados de Polícia com o Estado. São Paulo, EDUFScar/Sumaré/Fapesp.

BOURDIEU, Pierre (1999). A Dominação Masculina. Rio de Janeiro: Bertrand Brasil.

ELIAS, Norbert \& SCOTSON, John L. (2000). Os Estabelecidos e os Outsiders: Sociologia das Relações de Poder a partir de uma Pequena Comunidade. Rio de Janeiro: Jorge Zahar.

FREIDSON, Eliot (2001). Professionalism: The Third Logic. Oxford, UK: Polity.

GIDDENS, Anthony (1993). A Transformação da Intimidade: Sexualidade, Amor e Erotismo nas Sociedades Modernas. São Paulo: Editora da Unesp.

HOLLOWAY, Thomas H. (1997). Polícia no Rio de Janeiro: Repressão e Resistência numa Cidade do Século XIX. Rio de Janeiro: Fundação Getúlio Vargas. 
MONET, Jean-Claude (2001). Polícias e Sociedades na Europa. São Paulo: Edusp.

REINER, Robert (2000). The Politics of the Police. Oxford, Oxford University Press.

SOUZA, Luiz Antonio Francisco de (1998). Poder de Polícia: Polícia Civil e Práticas Policiais na Cidade de São Paulo (1889-1930). Tese de doutorado, São Paulo: FFLCH-USP.

\section{A Formação Acadêmica dos Delegados de Polícia}

Humberto Dantas

Desde a primeira metade do século $\mathrm{XX}$, um dos critérios exigidos para o exercício da profissão de delegado de polícia no Brasil é o título de bacharel em Direito. Há, contudo, casos de profissionais que tomaram posse do cargo sem apresentar esse diploma. Nos estados pesquisados, a despeito de todos os entrevistados possuírem a titulação, atualmente, dezessete entre eles ${ }^{1}$ foram nomeados antes da data de formatura: sete em São Paulo, seis no Rio Grande do Sul, um no Rio de Janeiro, um no Amapá, um na Bahia e um no Distrito Federal. O objetivo deste artigo é discutir se a existência de diferenças entre as faculdades de Direito cursadas pelos entrevistados responde por diferenças no modo de pensar e nas características socioeconômicas dos 1.228 delegados que responderam à pesquisa ${ }^{2}$.

Desde que o governo deixou de controlar e possuir o monopólio sobre o ensino jurídico, em 1891, surgiram muitas críticas a respeito do nível das instituições criadas ao longo do século XX. Enquanto algumas poucas escolas podiam ser citadas como exemplos de excelência, a maioria era vista como sinônimo da falta de qualidade ${ }^{3}$. Em 1996, mais de um século depois da liberalização, uma decisão do governo federal tornou possível a quantificação das diferenças na qualidade do ensino de Direito oferecido no país ${ }^{4}$. No último ano de faculdade, os formandos passaram a realizar exames de conhecimentos específicos na área jurídica. O resultado foi apresentado sob a

\footnotetext{
${ }^{1}$ Esse número representa $1,4 \%$ do total da amostra pesquisada.

${ }^{2}$ Apesar de a pesquisa ter sido respondida por 1.228 delegados, em 21 questionários não foi possível identificar a escola cursada ou não constava essa informação. Dessa forma, as análises nesse artigo tomarão por base a formação de 1.207 delegados.

${ }^{3}$ Ver a esse respeito, Venâncio Filho (1982).

${ }^{4}$ Essa medida não é exclusiva dos cursos jurídicos. O MEC vem, inclusive, ampliando o número de carreiras avaliadas anualmente. A atividade ficou conhecida como Provão ou Exame Nacional de Cursos.
} 
forma de conceitos hierarquizados - do "A" para as melhores escolas até o "E" para as piores - e demonstrou a diversidade entre as instituições 5 .

Nesse período, o número de faculdades saltou de duas, em 1891, para mais de 500 no início do século XXI. Porém, até 2001, apenas um pouco mais da metade das escolas em funcionamento - 276 -, havia formado turmas. Isso nos permite concluir que, em um período de menos de cinco anos, quase dobrou a quantidade de escolas de Direito no Brasil ${ }^{6}$.

O Exame Nacional de Cursos, popularmente conhecido como Provão, foi boicotado por algumas faculdades de Direito em suas primeiras edições, em 1996 e em 1997. Mesmo assim, é possível notar a existência de diferenças entre os cursos oferecidos. No estado de São Paulo, por exemplo, as escolas estaduais, as pontifícias universidades católicas e algumas poucas escolas privadas destacam-se no que se refere ao desempenho de seus alunos. Os resultados do MEC, no entanto, devem ser relativizados, uma vez que de acordo com a metodologia de cálculo, sempre existirão as escolas " $\mathrm{A}$ " e as instituições " $E$ ", ou seja, as que ocuparão as piores e as melhores posições independentemente de serem boas ou ruins de forma isolada. A despeito dessa observação, para os fins deste trabalho, organizamos os conceitos do Provão em cinco categorias numéricas - sendo o $\mathrm{A}=10$, o $\mathrm{B}=7,5$, o $\mathrm{C}=5$, o $\mathrm{D}=2,5$ e o $\mathrm{E}=0$ - e calculamos a média de cada instituição de ensino jurídico. Utilizamos nesse exercício os resultados dos anos de 1998 até 2001. No Gráfico 1, apresentamos a distribuição das escolas de Direito de todo o país

${ }^{5}$ Em Dantas (2002) há uma análise das diferenças entre as escolas "A" e "E" de Direito em São Paulo.

${ }^{6}$ É importante salientar que no Exame Nacional de Cursos cada filial de uma mesma instituição de ensino é considerada isoladamente.

${ }^{7}$ Até 2001 os resultados eram divididos em faixas percentuais. As escolas de nível "A" eram as $12 \%$ melhores, as de nível "B" as $18 \%$ seguintes, as "C" as $40 \%$ intermediárias, as "D" as $18 \%$ piores e as "E" as $12 \%$ mais mal classificadas. Hoje em dia essa divisão é feita de acordo com a média geral da carreira e as escolas são classificadas de acordo com a quantidade de desvios padrões que se situem da média. Neste caso, as instituições "A" ficam a mais de um desvio acima da média, as escolas " $\mathrm{B}$ " entre 0,5 e 1 ; as "C" entre 0 e 0,5 abaixo ou acima; as "D" entre 0,5 e 1 abaixo; e as "E" mais de 1 desvio padrão abaixo da média geral. Ainda assim, os resultados dever ser relativizados, pois estar 1 desvio acima da média não indica, necessariamente, que uma escola tenha apresentado ótimos resultados. Uma análise pormenorizada do Provão e das diferenças entre escolas de Direito pode ser obtida em Junqueira (2000). de acordo com a média dos quatro exames do MEC. Das 276 instituições avaliadas até $2001,14,5 \%$ estão classificadas com o conceito " $\mathrm{A}$ " (uma vez que dezessete dentre elas obtiveram média dez); $18 \%$ conseguiram "B"; $33 \%$ "C"; $21 \%$ "D" e 13,5\% obtiveram o conceito "E". Registre-se que dez faculdades ficaram com média zero: oito no Rio de Janeiro e duas em São Paulo. Apesar de a divisão apresentada não demonstrar resultados muito diferentes da fórmula utilizada para o cálculo anual do Provão, nosso intuito foi atenuar possíveis desvios na avaliação de um curso em um determinado ano, fazendo com que cada escola ficasse situada em um conceito mais condizente com o nível do serviço prestado.

GRÁFICO 1: DISTRIBUIÇÃO PERCENTUAL DAS ESCOLAS DE DIREITO NO BRASIL CONFORME O CONCEITO MÉDIO DO PROVÃO (1998 A 2001)

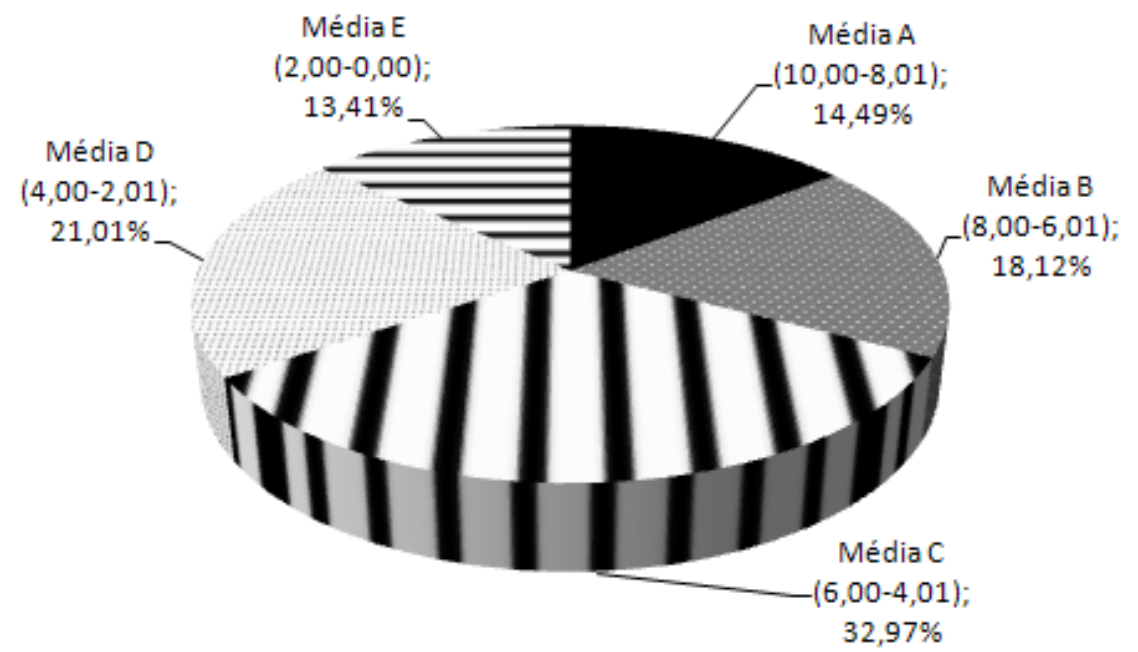

Fonte: MEC/INEP, 1999.

Apresentada a distribuição das escolas de acordo com a média do Exame Nacional de Cursos, passamos à discussão da influência do nível de ensino acadêmico na maneira como os delegados avaliam o funcionamento da Polícia Civil, bem como nas características pessoais dos delegados. Para isso, este artigo foi dividido em três partes. Na primeira será feita uma avaliação do nível de instrução dos entrevistados, classificando as escolas por eles frequentadas de acordo com os conceitos do Provão. Esses 
resultados serão comparados com dados de pesquisas anteriores, realizadas pelo Idesp, com juízes e integrantes do Ministério Público da União e dos estados. Em seguida, serão apresentados dados do MEC que mostram a existência de diferenças socioeconômicas entre os formandos das melhores e das piores faculdades de Direito. No segundo item utilizaremos a origem acadêmica dos delegados como variável dependente, explicada por suas características pessoais, familiares e sociais. Nesse caso, a qualidade do diploma jurídico obtido estaria sendo determinada pelo grau de instrução dos pais, pela quantidade de irmãos, pela cor da pele, dentre outros. Esses dados serão comparados com os obtidos na pesquisa socioeconômica do MEC, com o intuito de detectar se, também entre os delegados, existiriam diferenças de acordo com o conceito da escola cursada. Por fim, na terceira parte, analisaremos se o nível da formação acadêmica dos delegados de polícia no Brasil, agrupado de acordo com a média do Provão (1998-2001), pode servir como variável explicativa do posicionamento desses profissionais perante questões de ordem organizacional da Polícia, opiniões sobre Segurança Pública, entre outras.

O estudo aqui proposto possui uma limitação óbvia: supor que delegados formados há muito tempo receberam de suas instituições um estudo do mesmo nível que tais entidades continuam oferecendo hoje em dia, mesmo sendo os resultados compostos por médias de quatro anos de avaliação. Pois, como se sabe, o Provão é recente e avalia o ensino atual, enquanto os delegados entrevistados, ou boa parte deles, formaram-se há bastante tempo. Apesar desse obstáculo, que implica a crença em uma imutabilidade de todo improvável na prestação do serviço de ensino e descarta o caráter relativo do Provão, julgamos que a análise pode revelar aspectos interessantes relacionados ao perfil demográfico e ideológico dos delegados.

\section{A FORMAÇÃO DOS DELEGADOS}

Em termos de prestígio, o delegado de polícia não conta com o mesmo status dos integrantes do Ministério Público e da magistratura. Seja pelos vencimentos relativamente reduzidos na maioria dos estados do Brasil, ou devido à periculosidade das atividades exercidas ou ainda por uma quantidade menor de garantias de carreira, a preferência pela carreira de juiz, por exemplo, é maior entre os estudantes de Direito do que a de delegado de polícia. Em pesquisa realizada em 1999 pelo Ministério da
Educação com todos os formandos dos cursos de Direito que realizaram o Provão, 26\% gostariam de seguir a carreira de juiz, enquanto apenas $10 \%$ destacaram a preferência pela polícia. Se separadas em conceitos - do "A" ao "E" -, as respostas revelam que nas instituições que receberam as piores avaliações o interesse pelas delegacias de polícia é três vezes maior $-12 \%$ - contra apenas $4 \%$ entre as demais.

O Gráfico 2 mostra onde se formaram os delegados entrevistados em comparação à nota média do Exame Nacional de Cursos de 1998 a 2001. É possível perceber que, assim como no caso da distribuição das escolas (Gráfico 1), o conceito " $\mathrm{C}$ " predomina sobre os demais, com $32 \%$ dos diplomas. O desequilíbrio fica por conta das melhores ("A"/"B") e das piores ("D"/"E") escolas. No primeiro caso, há um superávit em relação ao número de faculdades ( $42,8 \%$ de delegados contra $32,5 \%$ de instituições) e no segundo um déficit ( $25,2 \%$ de profissionais contra $33,5 \%$ de faculdades). Segundo dados do Ministério da Educação, o interesse dos alunos das piores escolas pela carreira de delegado de polícia é maior. Isso revela uma diferenciação no interior das faculdades responsáveis pelo ensino jurídico. Provavelmente, a maioria dos candidatos nos concursos das academias de polícia provém de instituições "D"/"E", o que não se repete, contudo, na lista dos aprovados. Essa discrepância é explicada por algo esperado: a qualidade do ensino jurídico é um importante diferencial para a aprovação em concursos para delegado, assim como o é em outras carreiras públicas e no Exame de Ordem ${ }^{8}$.

\footnotetext{
${ }^{8}$ Em Dantas (2002) mostro que, para os concursos do TJ/SP e do Exame de Ordem da OABSP (primeira fase), as melhores escolas têm um índice aproximado de aprovação de respectivamente, $4 \%$ e $82 \%$ enquanto as piores instituições apresentam $0,5 \%$ e $23 \%$.
} 
GRÁFICO 2: DISTRIBUIÇÃO PERCENTUAL DOS DELEGADOS NO BRASIL CONFORME O CONCEITO MÉDIO DO PROVÃO (1998-2001) DAS ESCOLAS DE DIREITO FREQUENTADAS

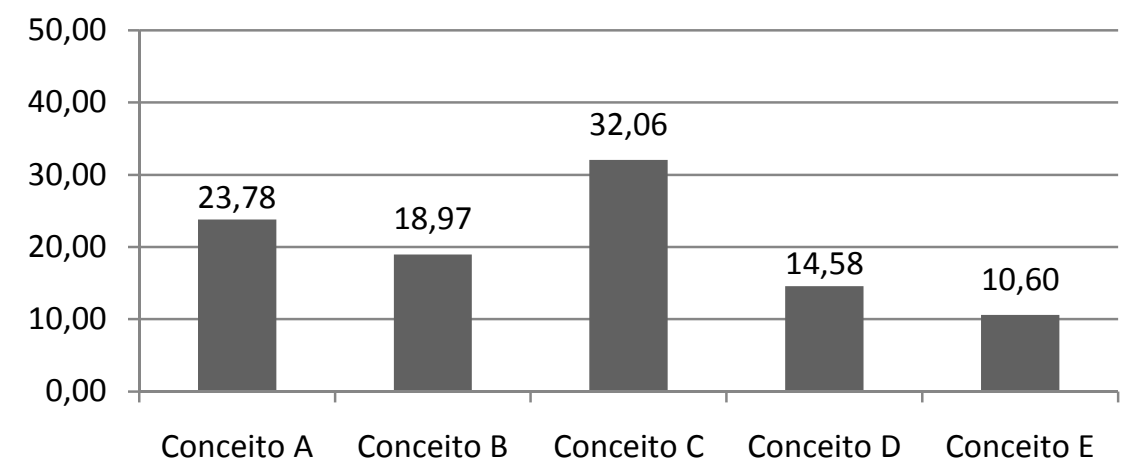

\section{Fonte: IDESP e MEC/INEP, 1999.}

Se comparados aos juízes e membros do Ministério Público, os delegados de polícia possuem um nível significativamente inferior na qualidade da formação acadêmica. O Gráfico 3 mostra a divisão desses profissionais ${ }^{9}$ por conceito do Provão.

Entre os juízes e os membros do Ministério Público federal e dos estados a presença dos diplomas das melhores escolas ("A") é marcante. Em nenhuma das três carreiras o índice fica abaixo dos 50\% e no Ministério Público federal chega quase a dois terços. Se somados os conceitos "A" e "B" os percentuais superam $70 \%$ nos três casos. Essa superioridade, consequentemente, afeta os demais conceitos. As escolas " $C$ ", que representam um terço das instituições, não alcançam percentual superior a $23 \%$, enquanto as piores faculdades ("E") ficam abaixo dos $3 \%$. Com relação a essa predominância, a pesquisa do MEC revelou que um quarto dos alunos das escolas "A" e um quinto dos bacharéis das instituições " $\mathrm{E}$ "

${ }^{9}$ Nos órgãos públicos, as pesquisas foram feitas pelo Idesp, dirigidas por Maria Tereza Sadek. Foi obtida a formação acadêmica de: 1.207 delegados de nove estados do Brasil, em 2001/ 2002; 495 juízes estaduais de cinco estados, em 1993; 222 membros do Ministério Público Federal de 23 estados, em 1997; e 711 membros do Ministério Público Estadual de sete estados, em 1996 gostariam de seguir a carreira de juiz. Os altos índices de ocupação das vagas pelos diplomados das boas escolas, somados ao interesse coletivo pela carreira, revelam novamente que o nível do ensino pode servir de diferencial para a aprovação em concursos públicos.

GRÁFICO 3: DISTRIBUIÇÃO PERCENTUAL DOS DIPLOMAS DOS DELEGADOS, JUÍZES, MEMBROS DO MINISTÉRIO PÚBLICO FEDERAL E DOS ESTADOS E ESCOLAS, SEGUNDO O CONCEITO MÉDIO DO PROVÃO (1998-2001)

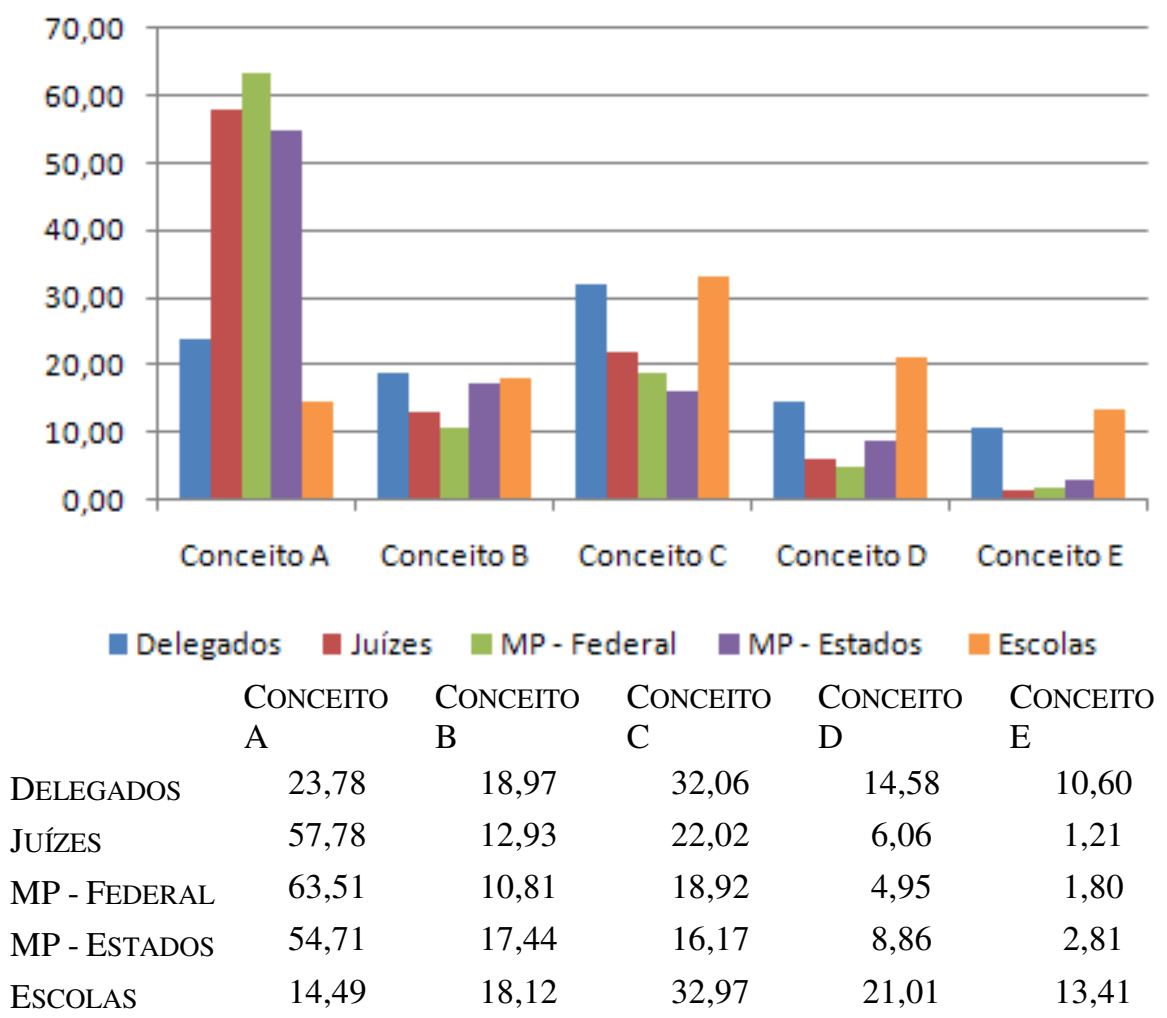

A despeito dessa superioridade no desempenho dos alunos das melhores instituições é importante destacarmos que as diferenças não estão concentradas somente no nível do ensino recebido nas faculdades. Com os dados da pesquisa de 1999 do MEC é possível constatar dessemelhanças 
sociais e econômicas marcantes entre os alunos das melhores ("A") e das piores faculdades ("E"), além de distinções estruturais e metodológicas entre as instituições de ensino. Na Tabela 1 apresentamos essas diferenças divididas em dois grupos: bacharel e escola. O primeiro mostra a renda média, a formação escolar dos pais, o tamanho da família, o estado civil etc. No segundo são apontadas as diferenças entre as faculdades quanto ao método de ensino, mecanismos de avaliação etc.

Podemos notar que os alunos e as escolas guardam profundas diferenças em relação às notas médias do Exame Nacional de Cursos. A Tabela 1 nos mostra que o argumento defendido por Sampaio, Limongi e Torres (2000) de que brancos, "ricos", formados em escolas particulares no ensino médio e com pais detentores de diplomas de nível superior ocupam as vagas das melhores faculdades é empiricamente verificado para o caso dos cursos jurídicos. Além disso, os alunos das piores instituições possuem renda média familiar inferior, têm um número maior de irmãos e quase um terço é casado e vive com o cônjuge e os eventuais filhos.

Da mesma forma que seus estudantes possuem condições socioeconômicas inferiores, as piores escolas apresentam métodos de ensino menos rigorosos. Sem a pretensão de resolver a causalidade desse fenômeno, notamos significativas diferenças. De fato, em mais de um terço das faculdades conceituadas com "E", as classes têm mais de cinquenta alunos; em cerca de um quinto delas, os professores utilizam resumos e apostilas como material didático; e, em 13\%, as provas são feitas na forma de testes de múltipla escolha, enquanto em menos de $1 \%$ das melhores instituições esse método é utilizado ${ }^{10}$.

Partindo da verificação de que existem diferenças entre os bacharéis de acordo com o conceito das faculdades, é de se esperar sua reprodução entre os delegados de polícia. A partir de agora concentraremos nossa análise na dependência da origem acadêmica em relação a outras variáveis que possam explicar as dessemelhanças existentes no nível dos diplomas jurídicos dos entrevistados. Os dados da Tabela 1 servirão de base para testarmos se as diferenças detectadas pelo MEC são repetidas na Polícia

${ }^{10}$ Em Dantas (2002), essas diferenças são pormenorizadamente detalhadas para o caso do estado de São Paulo.
Civil ou se existe, a despeito da origem acadêmica, uma homogeneização dos integrantes dessa carreira em torno de determinadas características.

TABELA 1: DIFERENÇAS NOS CONCEITOS DO PROVÃO DE 1999 ENTRE AS MELHORES (A) E AS PIORES (E) ESCOLAS DE DIREITO (EM \%)

\section{BACHAREL}

Renda familiar abaixo dos $\mathrm{R} \$ 2.601,00$

Pai com nível escolar superior

Mãe com nível escolar superior

Tem dois irmãos ou mais (famílias grandes)

É casado (percentual semelhante aos que moram com o

cônjuge e eventuais filhos)

Considera-se negro ou pardo

ESCOLAS ESCOLAS

A

E

Carga integral de trabalho (40h) durante o curso (exceto estágio)

Frequentou o ensino médio em escola privada

Dedicou mais de oito horas semanais aos estudos

ESCOLA

Aulas com mais de 50 alunos na classe

Os professores utilizam resumos e apostilas como material didático

Os professores utilizam livros e textos como material didático

As provas são no formato de testes de múltipla escolha Fonte: MEC/INEP - pesquisa do Provão 1999.

\section{A FORMAÇÃO COMO VARIÁVEL DEPENDENTE}

Nessa parte, desenvolvemos o argumento segundo o qual algumas características socioeconômicas dos delegados podem explicar as diferenças nos níveis dos diplomas obtidos pelos entrevistados. Partimos do suposto que, assim como na pesquisa do MEC de 1999, dentre os delegados formados nas escolas bem conceituadas a proporção de pais com nível de educação superior é maior que a encontrada entre aqueles advindos de instituições conceituadas com "E", por exemplo. 
Para realizar esse teste, utilizaremos algumas variáveis do survey do Idesp, que também se encontram na pesquisa do Ministério da Educação e podem contribuir para apontar distinções entre os delegados. Os resultados guardam semelhanças entre si e comprovam a existência de diferenças socioeconômicas entre os componentes da carreira analisada de acordo com o nível médio da escola cursada. A Tabela 2 contém as variáveis da pesquisa dos delegados de polícia que podem ser comparadas aos dados do Ministério da Educação de 1999.

TABELA 2: DIFERENÇAS ENTRE OS DELEGADOS DE ACORDO COM OS CONCEITOS MÉDIOS DO PROVÃO (1998-2001) ENTRE AS MELHORES (A) E AS PIORES (E) ESCOLAS DE DIREITO (EM \%)

Pai com nível escolar superior

$\begin{array}{cc}\text { ESCOLAS A } & \text { ESCOLAS E } \\ 39,7 & 15,7 \\ 24,5 & 10,0 \\ 70,5 & 74,6 \\ 8,0 & 14,9\end{array}$

Tem dois irmãos ou mais

Considera-se negro ou pardo

8,0

Fonte: Pesquisa Idesp, 2002, “Quem são e o que pensam os delegados de polícia”.

Entre os bacharéis em Direito que se classificam como negros ou pardos, o levantamento do MEC revelou que a presença nas escolas "E" é $100 \%$ maior que nas instituições "A", enquanto no caso dos delegados essa diferença é de cerca de $85 \%$. Com relação ao grau de escolaridade dos progenitores, nas escolas "A" o índice de pais com diploma de nível superior é cerca de $150 \%$ maior que nas piores escolas, em ambas as pesquisas. No caso das mães, os dados dos delegados mostram uma diferença de $145 \%$ e os do MEC de $200 \%$. Com relação à quantidade de irmãos, as informações não revelaram diferenças estatisticamente significativas.

Exceto por esse dado, a análise da formação acadêmica dos delegados de polícia como variável dependente mostrou que, a exemplo dos dados do Ministério da Educação, fatores socioeconômicos podem explicar as distinções entre os conceitos médios das escolas cursadas.

\section{A FORMAÇÃO COMO VARIÁVEL EXPLICATIVA (INDEPENDENTE)}

Partindo da existência de distinções que demonstraram ir além da escola cursada, esperamos encontrar entre os delegados - de acordo com o

conceito médio do Provão - diferenças em relação às opiniões sobre o funcionamento da polícia, a reforma da corporação e alguns temas abordados pela pesquisa do Idesp. A origem acadêmica seria uma variável explicativa relevante, caso fossem notadas alterações entre os conceitos ${ }^{11}$. Em contrapartida, a ausência de variações apontaria para um alto grau de homogeneidade entre os delegados, permitindo supor que o discurso dos integrantes da corporação não é influenciado pela qualidade do diploma e de suas decorrências socioeconômicas.

Seguindo o roteiro de perguntas do questionário utilizado pelo Idesp, as opiniões dos delegados sobre os mais variados temas foram divididas em nove grupos, que serão analisados a seguir:

a) Características relevantes para ser um bom delegado.

b) Fatores que influenciaram na decisão de seguir a carreira.

c) Obstáculos ao bom funcionamento da polícia.

d) Propostas para a melhoria da Polícia Civil.

e) Propostas para a melhoria da segurança pública.

f) Propostas para a melhoria do sistema criminal.

g) Opinião sobre temas polêmicos relacionados ao funcionamento da polícia.

h) Avaliação da importância de certos fatores na construção de uma imagem negativa da polícia.

i) Avaliação da relação da Polícia Civil com outros segmentos da sociedade.

Dividimos a interpretação desse conjunto de questões em dois agrupamentos distintos. No primeiro caso, todos os itens de cada um desses tópicos foram cruzados com o nível do ensino recebido nas faculdades. No segundo agrupamento foram analisados pontualmente alguns itens relacionados ao ensino e às conclusões retiradas da pesquisa do MEC de 1999.

${ }^{11}$ Esclarecendo que as diferenças acadêmicas, como mostrado anteriormente, carregam dessemelhanças socioeconômicas significativas. 
As opiniões sobre as propostas de melhoria da Polícia Civil (variável d), da segurança pública (e) e do sistema criminal (f) assim como o posicionamento perante alguns temas polêmicos $(\mathrm{g})$, os fatores que auxiliam na criação de uma imagem negativa da corporação (h) e a relação da Polícia Civil com determinados segmentos da sociedade (i) foram cruzados com o nível do ensino superior recebido pelos delegados e não demonstraram quaisquer variações relevantes. Dos quarenta itens submetidos à opinião dos delegados, não constatamos distinções na forma de pensar dos bacharéis advindos de instituições avaliadas com os conceitos médios "A" ou "E" do Provão. Isso revela uma uniformização do pensamento dos membros dessa carreira, deixando claro que a origem acadêmica e seus condicionantes parecem exercer pouca influência sobre a opinião atual dos delegados.

Além da não existência de diferenças entre os diversos níveis de ensino, a concentração de respostas em torno de uma mesma alternativa $^{12}$ revela um alto grau de homogeneidade no discurso dos delegados de polícia. Alguns exemplos apresentados na Tabela 3 podem reforçar essa afirmação. Nesses casos, salientamos que as respostas "importante" e "muito importante" foram somadas, assim como "pouco importante" e "sem importância"; "concorda totalmente" e "concorda em termos"; e "discorda em termos" e "discorda totalmente".

Apesar de não ser nosso objetivo pormenorizar as razões que determinam ou influenciam os resultados da Tabela 3 e sim demonstrar que não há diferenças nas opiniões dos delegados formados nas mais diferentes escolas jurídicas, é importante notar o grau de concordância em torno de algumas questões. Isso nos leva à conclusão de que a origem acadêmica e as características socioeconômicas associadas a essa distinção não interferem no modo de o delegado opinar sobre a segurança pública e a reforma da Polícia Civil, entre outros.

No segundo agrupamento de questões estão contidas algumas respostas relacionadas ao ensino jurídico e à importância da faculdade na formação dos delegados. Essas variáveis serão analisadas de forma mais detalhada. Antes, porém, já é possível adiantar que os resultados pouco

\footnotetext{
${ }^{12}$ Isso ocorreu em grande parte das respostas.
}

contribuíram para sustentar o argumento segundo o qual os delegados diplomados nas melhores escolas manifestam opiniões divergentes daqueles que estudaram nas piores instituições. A análise levará em conta as variáveis: características relevantes para ser um bom delegado (variável a); fatores que influenciaram na decisão de seguir a carreira (b); e obstáculos ao bom funcionamento da polícia (c).

TABELA 3: VARIÁVEIS QUE APRESENTARAM RESPOSTA HOMOGÊNEA E NÃO DEMONSTRARAM DIFERENÇAS ENTRE OS CONCEITOS ACADÊMICOS (MÉDIA DO PROVÃO DE 1998-2001) (EM \%)

OPINIÃO

Concordam com a criação de grupos especiais para o combate ao crime organizado

Concordam com o aumento da fiscalização das empresas de segurança privada

Concordam com a implementação de conselhos comunitários de segurança pública

Consideram sem importância a direção da investigação policial pelo Ministério Público

Consideram sem importância a criação de grupos de investigação no Ministério Público

Consideram importante a instalação de juizados especiais nas delegacias de polícia

Consideram importante a existência de plantão judiciário de $24 \mathrm{~h}$

Consideram importante o delegado voltar a fazer busca domiciliar sem mandado judicial

Concordam que "a maior parte da população não tem acesso à justiça"

Discordam que "a violência é inerente à função policial"

Concordam que "bons e maus cidadãos devem ter seus direitos igualmente respeitados"

Concordam que a violência policial tem peso importante na imagem negativa da polícia

Concordam que o sensacionalismo dos meios de comunicação prejudica a imagem da polícia

Concordam que as acusações de corrupção prejudicam a imagem da polícia

Concordam que o tratamento dispensado à população prejudica a imagem da polícia

Fonte: Pesquisa Idesp, 2002, “Quem são e o que pensam os delegados de polícia”. 
Quando indagados sobre os fatores considerados relevantes na formação de um bom delegado, todos os entrevistados, provenientes de todos os níveis de escolas de Direito, apontaram o saber jurídico como importante. Essa mesma totalidade foi verificada em outros dois itens relacionados ao conhecimento das leis: capacidade de preparar inquéritos bem circunstanciados e competência técnica para o trabalho de investigação. Nesses três casos foi possível constatar a existência de uma avaliação homogênea sobre a importância do saber específico para o exercício da profissão, independentemente da qualidade do curso superior frequentado antes de se tornar delegado.

Além de julgarem fundamental o saber jurídico, 90\% dos entrevistados, sem distinção entre os provenientes das diferentes faculdades, indicaram que a formação deficiente dos delegados pode ser considerada um importante obstáculo ao bom funcionamento da Polícia Civil. Restaria saber, nessa avaliação, qual a parcela de responsabilidade que deveria ser imputada ao treinamento recebido nas Academias de Polícia e qual a do ensino recebido nas faculdades.

A única questão diretamente relacionada aos cursos jurídicos que apresentou um desvio discreto, entre os delegados advindos de distinto nível de ensino, está ligada à influência que os professores exerceram sobre a decisão de cada entrevistado seguir a carreira policial. Na Tabela 4 apresentamos esses números.

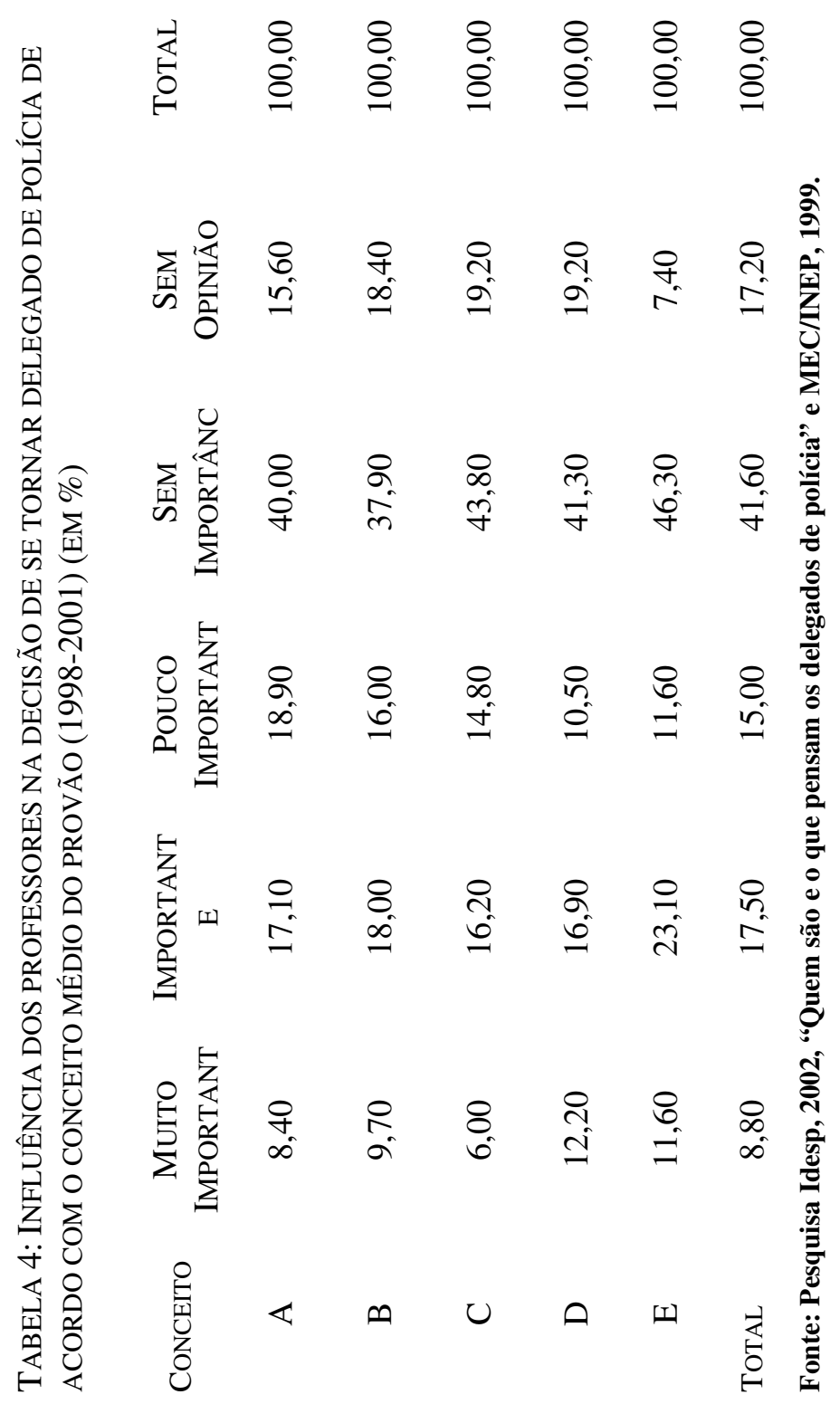


Se somarmos as alternativas "Muito Importante" e "Importante", como fizemos em todos os casos até aqui apresentados, um quarto dos delegados formados nas escolas de nível "A" $(25,5 \%)$ acreditam na importância de seus professores na decisão de se tornarem delegados. Esta participação sobe para mais de um terço $(34,7 \%)$ entre os profissionais diplomados nas piores instituições. Nesse caso, é importante salientar que de acordo com a pesquisa do MEC de 1999 o direito penal - matéria mais relacionada ao exercício da carreira de delegado de polícia - é a disciplina mais bem ministrada em $34,1 \%$ das escolas "E" e em $23,5 \%$ das escolas "A", de acordo com a opinião dos alunos. Tal percepção talvez explique o maior interesse dos formandos das piores instituições pela carreira policial.

Outros dois itens que poderiam revelar diferenças entre os delegados de acordo com o nível da faculdade cursada é a importância atribuída à "remuneração" e à "falta de opção no mercado de trabalho". No primeiro item, não há distinção estatisticamente significativa: enquanto $68,1 \%$ dos delegados provenientes das melhores escolas apontaram como importante o fator remuneração, 74,4\% dos profissionais das piores faculdades também o fizeram.

Como os vencimentos da carreira podem variar de acordo com a unidade da federação, partimos do suposto que quanto mais alto o vencimento, maior o número de detentores dos melhores diplomas e mais elevada a importância desse fator na decisão de ingressar na carreira. Essa hipótese, porém, não é corroborada pelos dados. Isso poderia ser explicado pelo fato de o Provão ter abrangência nacional e alguns estados pesquisados não contarem com escolas de nível "A". Ressalte-se que o percentual de ocupação do cargo de delegado por nativos de um determinado estado é significativamente elevado, ficando acima de $85 \%$ em cinco locais (Bahia/Pernambuco/Rio de Janeiro/Rio Grande do Sul/São Paulo) e abaixo de um terço somente no Amapá $(32,4 \%)$ e no Distrito Federal $(21,9 \%)$. Se considerarmos o estado de formatura, em vez da unidade de nascimento, aquela proporção chega aos $70 \%$ em oito estados e supera os $95 \%$ em Pernambuco, no Rio Grande do Sul, no Rio de Janeiro, em São Paulo e na Bahia. A única exceção é o Amapá, onde não há delegado formado no próprio estado. Isso pode ser explicado pela existência de somente duas faculdades de Direito em Macapá, pela pouca tradição dessas escolas - inauguradas há somente dez anos - e pela avaliação média obtida entre 1998 e 2001 ("C" e "D”).

A despeito da divisão estadual dos diplomas, em três das nove unidades federativas pesquisadas, mais de $58 \%$ dos delegados declararam salários superiores a R\$ 6.000,00. São eles: Distrito Federal (95,4\%), Paraná $(85,3 \%)$ e Rio Grande do Sul $(58,2 \%)$. Nesses casos, a remuneração é apontada como um fator "muito importante" por mais de $30 \%$ dos delegados; e no Distrito Federal, onde os vencimentos são maiores, esse percentual supera 48 pontos. Mesmo nesses estados, não há distinção entre os conceitos médios do Provão, ou seja, a opinião dos delegados acerca da remuneração não é destoante em decorrência do nível da escola cursada.

No segundo item, que trata da "falta de opção no mercado de trabalho", os dados revelam que apenas $7,6 \%$ dos entrevistados formados em escolas "E" consideraram essa variável "importante", enquanto 11,7\% dos bacharéis das melhores escolas destacaram a relevância desse fator. Apesar dessa pequena diferença, é importante ressaltar que entre os entrevistados, as respostas não sugerem ter prevalecido o temor quanto às dificuldades impostas pelo mercado de trabalho quando da decisão de fazer o concurso.

Entre os outros itens selecionados, a experiência anterior na polícia pode revelar algumas características interessantes. Nesse caso, também observamos a importância atribuída aos parentes e conhecidos na decisão de se tornar delegado. Enquanto exatamente $20 \%$ dos entrevistados formados em escolas de nível "A" apontaram esse fator como relevante, mais de um terço $(34,7 \%)$ dos diplomados nas piores instituições o fizeram. Se analisarmos, paralelamente, o conjunto de delegados que reconheceu que experiências anteriores na Polícia impulsionaram tal decisão, teremos $61 \%$ de entrevistados das escolas "E" optando por essa resposta, contra "apenas" $34,8 \%$ dos bacharéis das faculdades " $\mathrm{A}$ ".

Em face desses dados, poderíamos, por meio de uma hipótese meramente casual, supor que os primeiros, já ativos na polícia, buscaram ascender na carreira, enquanto o segundo grupo - dos alunos das melhores faculdades - procurou a estabilidade de um cargo público, fator considerado uniformemente importante por $80 \%$ dos delegados. As análises das experiências profissionais anteriores e dos concursos públicos prestados 
podem corroborar essa afirmação ${ }^{13}$. Os alunos das piores instituições teriam vindo de cargos mais baixos no nível hierárquico da Polícia Civil, e os bacharéis das melhores escolas teriam prestado outros concursos públicos para outras carreiras, como a Magistratura, a Procuradoria e o Ministério Público. Além disso, esses bacharéis teriam exercido, em maior proporção, antes da função de delegado, a advocacia.

Essas hipóteses podem ser verificadas na Tabela 5. Nesse exercício foram considerados apenas os concursos para os cargos de nível superior que conferem notoriedade ao aprovado (Magistratura, Procuradoria e Ministério Público) e os cargos intermediários da polícia - com destaque para investigador, agente, escrivão e perito. Outros tipos de provas foram desconsiderados.

Entre os alunos dos melhores cursos, menos de um quarto $(24,0 \%)$ procurou - descartados os concursos para outras áreas - ocupar cargos intermediários na Polícia Civil. Essa alternativa de trabalho, entre os provenientes das piores escolas, atinge quase a metade dos entrevistados $(48,4 \%)$. Já nas carreiras que exigem curso superior, aproximadamente um terço dos formados nas faculdades classificadas com "A" tentaram uma vaga de juiz, promotor ou procurador $(31,7 \%)$, enquanto menos de um quinto dos alunos das instituições "E" o fizeram $(18,8 \%)$.

TABELA 5: CONCURSOS PRESTADOS ANTERIORMENTE PELOS DELEGADOS DE POLÍCIA DE ACORDO COM O MELHOR E O PIOR CONCEITO MÉDIO DO PROVÃO (1998-2001) (EM \%)

$\begin{array}{lccccc}\text { CONCEITO } & \text { DELEGAdo } & \text { SUPERIORES } & \text { PolícIA } & \text { POLÍ́cIA E } & \text { TotAL } \\ \text { A } & 42,2 & 31,7 & 24,0 & 2,1 & 100,00 \\ \text { E } & 31,3 & 18,8 & 48,4 & 1,6 & 100,00\end{array}$

Obs.: Os demais concursos foram desconsiderados.

Fonte: Pesquisa Idesp, 2002, "Quem são e o que pensam os Delegados de Polícia" e MEC/ INEP, 1999.

${ }^{13}$ Nesses dois casos, a origem acadêmica assume, novamente, a característica de variável dependente.
TABELA 6: ATIVIDADES EXERCIDAS ANTES DA POSSE DO CARGO DE DELEGADO DE POLÍCIA DE ACORDO COM O MELHOR E O PIOR CONCEITO MÉDIO DO PROVÃO (1998-2001) (EM \%)

$\begin{array}{cccccc}\text { Conceito } & \text { Advogado } & \text { Polícla } & \begin{array}{c}\text { Polícia E } \\ \text { AdVOgados }\end{array} & \begin{array}{c}\text { SEM OCUPAÇão } \\ \text { ANTERIOR/OUTRAS }\end{array} & \text { TotAL } \\ \text { A } & 35,3 & 28,3 & 2,4 & 44,0 & 100,00 \\ \text { E } & 14,1 & 50,8 & 0,8 & 44,3 & 100,00\end{array}$

Fonte: Pesquisa Idesp, 2002 “Quem são e o que pensam os Delegados de Polícia” e MEC/ INEP, 1999.

$\mathrm{Na}$ Tabela 6, que trata das ocupações anteriores dos entrevistados, constata-se que mais de um terço dos bacharéis formados nas melhores escolas exerceu a profissão de advogado (35,3\%), enquanto cerca de $14 \%$ dos diplomados das piores escolas o fizeram. Tal diferença é compensada pelo percentual de delegados formados nas melhores instituições que trabalharam anteriormente na polícia $(28,3 \%)$ e os entrevistados provenientes das piores faculdades $(50,8 \%)$ que lá estiveram.

As demais questões relacionadas aos obstáculos que impedem o bom funcionamento da Polícia Civil e a opinião sobre as propostas de melhoria da corporação concentram respostas em torno de uma mesma opinião, ou são distribuídas uniformemente, de maneira independente do conceito atribuído à faculdade de Direito em que se formou o delegado.

\section{CONCLUSÃO}

A análise dos dados da pesquisa do Idesp, em conjunto com os resultados do Provão (avaliação realizada pelo MEC em 1999), revelou a existência de diferenças socioeconômicas entre os entrevistados, segundo o nível médio da escola cursada. Além disso, ainda do ponto de vista da origem acadêmica, são distintas a experiência profissional e a trajetória até a posse do cargo de delegado entre os profissionais provenientes de faculdades bem e mal avaliadas.

Notadas essas distâncias, seria de se esperar que a qualidade do ensino frequentado servisse como variável explicativa para uma série de possíveis diferenças de opinião e de percepção dos problemas entre os integrantes da Polícia Civil. Assim, delegados formados nas melhores instituições teriam uma visão distinta daqueles diplomados nas piores 
escolas sobre temas como: reforma do sistema de segurança pública, opiniões sobre o trabalho da polícia, propostas para a diminuição da criminalidade, entre outros. Nossa análise permite afirmar que, a despeito das diferenças acadêmicas e de suas condicionantes sociais e econômicas, o discurso dos profissionais mostrou-se, na maioria das questões, homogêneo. Ou seja, a hipótese inicial que contemplava a influência da qualidade da faculdade cursada no posicionamento dos delegados sobre temas atinentes à corporação e à segurança pública foi refutada.

Dificilmente se poderia atribuir essa homogeneidade à formação educacional superior - que se mostrou desigual. Parece mais razoável supor a atuação de três fatores contribuindo para essa uniformização: a) o papel da Academia de Polícia, que exerce significativa ascendência sobre os seus profissionais; b) a experiência como delegado, que constrói uma visão bastante semelhante a respeito dessa atividade e; c) o elevado grau de socialização na Polícia Civil. O peso de cada um desses fatores e de sua mútua relação para a construção de uma identidade de delegado de polícia não é possível de se mensurar com os dados disponíveis. De toda a forma, pode-se concluir que o treinamento e o exercício da profissão têm uma força significativa. Essa influência, certamente, é maior que a exercida por variáveis relacionadas ao período anterior ao ingresso na carreira.

\section{Referências Bibliográficas}

CASTILHO, Ela Wiecko V. \& SADEK, Maria Tereza (1998). O Ministério Público Federal e a Administração da Justiça no Brasil. São Paulo, Idesp/Sumaré.

DANTAS, Humberto (2002). Ensino Jurídico e Classe Política. Dissertação de mestrado, São Paulo, Faculdade de Filosofia, Letras e Ciências Humanas da Universidade de São Paulo.

INSTITUTO de Desenvolvimento Econômico, Social e Político de São Paulo (1994). A Crise do Judiciário Vista pelos Juízes. São Paulo.

JUNQUEIRA, Eliane Botelho (2000). "O Diabo Teplotaxl no Mundo do Direito: Indo além da Brincadeira com Números". Revista Plúrima, 4.
KLEIN, Lúcia (1992). Política e Políticas de Ensino Superior no Brasil: 1970-1990. São Paulo, Nupes.

MINISTÉRIO DA EDUCAÇÃO (2002). Fatos sobre a Educação no Brasil: 1994-2001. Brasília.

ORDEM dos Advogados do Brasil (1996). Ensino Jurídico: Parâmetros para Elevação de Qualidade e Avaliação. Brasília.

SADEK, Maria Tereza (org.) (2001). Acesso à Justiça. São Paulo, Konrad Adenauer Stiftung.

(org.) (1997). O Ministério Público e a Justiça no Brasil. São Paulo, Sumaré/Idesp.

SADEK, Maria Tereza \& DANTAS, Humberto (2000). "Os Bacharéis em Direito na Reforma do Judiciário: Técnicos ou Curiosos?” Revista São Paulo em Perspectiva, 14 (2): 101-111, abr./jun.

SAMPAIO, Helena (2000). Ensino Superior no Brasil: O Setor Privado. São Paulo, Hucitec/Fapesp.

(1991). Evolução do Ensino Superior Brasileiro, 1808-1990. São Paulo, Nupes.

SAMPAIO, Helena; LIMONGI, Fernando \& TORRES, Haroldo (2000). Equidade e Heterogeneidade no Ensino Superior Brasileiro. São Paulo, Nupes.

VENÂNCIO FILHO, Alberto (1982). Das Arcadas ao Bacharelismo (150 Anos de Ensino Jurídico no Brasil). 2. ed. São Paulo, Perspectiva. 


\section{Polícia Civil e Segurança Pública}

\section{Problemas de Funcionamento e Perspectivas de Reforma}

Rogério Bastos Arantes Luciana Gross Siqueira Cunha

\section{INTRODUÇÃO}

Embora tenha se acentuado recentemente, devido ao agravamento do problema da violência, o debate sobre a crise na Segurança Pública e a sua relação com as dificuldades de consolidação do Estado de Direito no Brasil não é novo e vem ocupando a atenção de especialistas e lideranças políticas há vários anos.

Praticada por agentes privados ou estatais, no campo e na cidade, a violência vem recebendo a atenção de analistas e do governo não só do ponto de vista dos seus fatores causais mais profundos, mas também no que diz respeito a medidas de curto e médio prazos, necessárias à intervenção imediata e à interrupção do seu crescimento generalizado. Já faz algum tempo que o debate sobre essa questão superou o paradigma clássico das "causas sociais da violência" - especialmente a pobreza e a exclusão social - que nos remeteriam à necessidade de mudanças estruturais da sociedade brasileira. Não que tais dimensões tenham sido abandonadas, mas as organizações sociais e estatais envolvidas com essa problemática têm cada vez mais se dedicado ao exame de soluções no campo específico da segurança pública, normalmente girando em torno da reforma institucional dos órgãos que compõem esse sistema e de mudanças na legislação pertinente.

A discussão relacionada ao combate à criminalidade difusa ou organizada e a redução da impunidade no Brasil também vem se orientando cada vez mais por esse prisma, ensejando a formulação de propostas de mudanças concretas na organização policial, na legislação penal e na justiça criminal.
Os diagnósticos sobre a ineficiência da polícia e a incapacidade do sistema de justiça de impedir o crime e promover a reparação esperada têm levado ao surgimento de propostas de reforma que vão desde um novo modelo de polícia, completamente distinto do atual, até a redefinição do papel do Ministério Público e do Poder Judiciário como órgãos responsáveis pela aplicação e cumprimento das leis.

É verdade também que o debate sobre causas e soluções da crise da Segurança Pública tem evoluído em meio a solavancos: a cada novo tipo de crime que surge ou a cada novo escândalo de corrupção ou abuso de poder envolvendo o aparato policial ou de justiça, mais uma intensa rodada de discussões é travada, para logo em seguida voltar ao banho-maria. Em outras palavras, embora já tenhamos acumulado várias evidências sobre essa crise, ainda estamos longe de um processo articulado e consequente de reforma institucional nessa área.

Nesse contexto, um dos objetivos da pesquisa "Quem são e o que pensam os delegados de polícia" foi revelar a opinião desses agentes a respeito da crise e de propostas de reforma legislativa e institucional do sistema de segurança pública. Tais questões foram agrupadas em quatro eixos principais, que resultaram nas perguntas números $23,24,25$ e 26 do questionário, respectivamente:

a) Fatores que aparecem como obstáculos ao bom funcionamento da Polícia Civil.

b) Propostas destinadas a melhorar especificamente o desempenho da Polícia Civil.

c) Propostas que dizem respeito ao sistema de segurança pública como um todo.

d) Propostas mais gerais que têm sido feitas para tentar reduzir a impunidade e a criminalidade, alterando o funcionamento do sistema penal.

A definição dessas questões deu-se com base na observação do debate público e acadêmico, acompanhada e refinada por meio de entrevistas qualitativas com delegados de polícia localizados em vários setores do aparato policial (de delegacias a órgãos de direção). 
O acompanhamento do debate sobre a segurança pública revelou que alguns atores têm assumido uma posição mais destacada na formulação de propostas de reforma. Dentre manifestações de várias instituições e entidades, o questionário acabou incorporando diagnósticos e propostas das associações de delegados de polícia, das ouvidorias de polícia, do Programa Nacional de Direitos Humanos e do Plano Nacional de Segurança Pública (ambos do governo federal), bem como as discussões que têm sido realizadas no Congresso Nacional sobre as reformas do Código de Processo Penal (CPP), do Poder Judiciário e do sistema de segurança pública, além de projetos de emenda constitucional versando sobre assuntos mais específicos.

$\mathrm{Na}$ próxima seção deste artigo descreveremos a montagem do questionário utilizado na pesquisa, realizada com base no mapeamento do debate público envolvendo esses diversos atores, em torno dos quatro eixos principais de questões mencionados acima. Na seção seguinte analisaremos os resultados do survey nesses quatro eixos, procurando destacar pontos de convergência e de divergência entre os entrevistados.

O MAPEAMENTO DO DEBATE ENTRE ASSOCIAÇÕES DE DELEGADOS, OUVIDORIAS DE POLÍCIA, GOVERNO FEDERAL E CONGRESSO NACIONAL

Desde a redemocratização do país e de sua reconstitucionalização em 1988, deficiências na atuação dos aparatos policiais civis e militares têm sido apontadas diante do amplo e desafiador leque de situações que vão do abuso de poder em casos de conflitos sociais (rurais e urbanos) até a incapacidade de prevenir e reduzir a criminalidade difusa ou organizada, passando pelos velhos problemas da tortura, da corrupção e da falta de transparência no funcionamento dos órgãos policiais.

Visões mais críticas e pessimistas desse cenário pós-democratização afirmam que o retorno do país ao regime constitucional e liberaldemocrático não foi capaz de promover um Estado de Direito efetivo. Nessa perspectiva, práticas autoritárias e desregradas do uso da força não teriam sido radicalmente alteradas ou suplantadas pela transição de regime político, nem aqui, nem nos demais países latino-americanos que passaram por processo semelhante. Nas palavras de Méndez, O’Donnel e Pinheiro:

$\mathrm{Na}$ maioria dos países latino-americanos, em especial naqueles países sem tradição de proteção aos direitos civis, mesmo depois da elaboração de novas Constituições democráticas, as instituições legais não foram reformadas e as práticas arbitrárias de agentes estatais da polícia e de outras instituições de controle da violência continuam as mesmas. Apesar de todos os avanços na sociedade civil e na governabilidade democrática, os pobres continuam a ser as vitimas preferenciais da violência, da criminalidade e da violação dos direitos humanos. Em contraste, o Estado, na maior parte da América Latina, se mostrou incapaz - ou melhor, sem vontade - de erradicar a impunidade por crimes cometidos por seus agentes, na mesma extensão que tenta punir os crimes cometidos por criminosos comuns sem meios ou recursos de poder (Méndez, O’Donnel e Pinheiro, 2000, p.14).

A despeito desse cenário negativo, é importante destacar que houve iniciativas importantes de melhoria do funcionamento dos órgãos policiais e de justiça e que o grau de conhecimento e discussão sobre o funcionamento dessas instituições é hoje bem maior do que tempos atrás, resultado justamente da transição para o regime democrático. Nossa análise orienta-se por esse debate e procura descrever como os atores envolvidos têm se posicionado diante do problema e das perspectivas de reforma.

No contexto da transição democrática, uma novidade importante foi a criação das chamadas ouvidorias de polícia, com a finalidade de aumentar o grau de controle público sobre os aparatos policiais, contribuindo para aperfeiçoar seu funcionamento. As ouvidorias de polícia, já instaladas em vários estados, recebem denúncias, reclamações e sugestões da população, produzem e publicam informações e estatísticas sobre a conduta dos policiais, além de se destacarem pela proposição de medidas para melhorar a segurança pública e aperfeiçoar os serviços prestados pela polícia ${ }^{1}$.

A Ouvidoria de Polícia do Estado de São Paulo é uma das que tem se destacado na produção de informações sobre a atividade policial e de propostas para o seu aperfeiçoamento. A partir das denúncias e críticas registradas, a Ouvidoria de Polícia de São Paulo formula sugestões de mudança legislativa e organizacional que são divulgadas por meio de

${ }^{1}$ A primeira ouvidoria de polícia instalada no Brasil foi a do estado de São Paulo, em 1995, seguida da Ouvidoria do Sistema de Segurança Pública do estado do Pará. Além dessas, já estão em funcionamento ouvidorias de polícia nos estados do Espírito Santo, Minas Gerais, Rio Grande do Sul, Rio de Janeiro, Bahia, Pernambuco, Ceará e Paraná. Para uma análise mais detalhada ver Cunha (2000). 
relatórios intitulados Ação Propositiva da Ouvidoria. Dentre medidas propostas pela ouvidoria, a pesquisa selecionou algumas para a avaliação dos delegados de polícia entrevistados. Com relação aos fatores que aparecem como "obstáculos ao bom funcionamento da Polícia Civil" (o primeiro dos quatro eixos de questões indicados acima), a Ouvidoria vem apontando desde 1998 a importância de melhorar a formação dos policiais civis e dos delegados, inclusive unificando progressivamente as academias e escolas de formação e estabelecendo convênios com as universidades para a formação do quadro policial (proposta $\mathrm{n}^{\circ} 18$, de 1998). A questão da formação deficiente de policiais e delegados foi abordada pela pesquisa, assim como o problema dos baixos salários e a necessidade de se buscar alternativas aos chamados "bicos", temas também levantados pelas ações propositivas 17 e 21 da Ouvidoria de Polícia de São Paulo, em 1998.

No que diz respeito às propostas para melhorar o desempenho da Polícia Civil (segundo eixo de questões), o questionário também trabalhou com algumas sugestões da ouvidoria paulista: fortalecer, dar competência estadual e estudar a possibilidade de criação de carreira própria para o órgão corregedor da Polícia Civil (ação propositiva 2, de 1998) e a reestruturação dos grupos e delegacias especializadas, propondo a extinção de alguns e a expansão de outros (ação propositiva 1, de 1998).

Da mesma forma, ao abordarmos o terceiro eixo de questões propostas para melhorar a segurança pública - buscamos elementos em algumas sugestões da ouvidoria, como a da ação propositiva 18 , que vê a necessidade de investigar e reprimir a prática de policiais serem donos de forma direta ou indireta de empresas de segurança privada.

O surgimento de ouvidorias de polícia em vários estados brasileiros levou à criação, em junho de 1999, do Fórum Nacional dos Ouvidores de Polícia ${ }^{2}$. Amplificando experiências e propostas das ouvidorias locais, o Fórum Nacional apresentou em dezembro de 1999 uma proposta de Projeto de Emenda Constitucional denominada "Um Novo Modelo de Polícia no Brasil". Dentre as principais medidas constavam a extinção do inquérito policial e das polícias civil e militar e a criação da Polícia Estadual, reunindo as funções de investigação e de policiamento preventivo e

${ }^{2}$ O Fórum foi criado por Decreto do Presidente da República e está vinculado à Secretaria de Estado dos Direitos Humanos do Ministério da Justiça. ostensivo, sob controle civil. Embora não tenha descido a detalhes nesse ponto, nossa pesquisa contemplou a questão da reforma da polícia, por meio da proposta de Unificação das Polícias Civil e Militar. É importante ressaltar, entretanto, que para além da proposta do Fórum Nacional existe uma variedade de sugestões em torno da reforma estrutural das polícias, formuladas pelas associações de classe do meio policial e judiciário, além de outras que têm sido discutidas no Congresso Nacional. Dados os limites da pesquisa, não foi possível explorar as diferentes concepções em torno dessa mudança estrutural das polícias Civil e Militar, mas apenas descobrir o grau de concordância dos delegados sobre o sentido geral dessa proposta.

O Projeto de Emenda Constitucional elaborado pelo Fórum Nacional dos Ouvidores de Polícia levou em conta diversos aspectos da atividade policial e preocupou-se com as condições de trabalho dos policiais, desde os baixos salários até a dimensão psicológica do exercício da função, passando pela denúncia do "bico" como trabalho paralelo que têm exposto os policiais a risco de vida superior ao enfrentado na atividade policial regular $^{3}$. Entretanto, para além do enfrentamento desses aspectos, que coincidem em parte com reivindicações das associações de classe de delegados e de policiais, os ouvidores reunidos no Fórum Nacional propuseram a) o fortalecimento das ouvidorias de polícia; b) a independência dos Institutos Médicos Legais e órgãos periciais em relação à Polícia Civil; e c) o controle externo da atividade policial pelo Ministério Público. Tais propostas, que implicam maior controle sobre a polícia, foram trabalhadas pela pesquisa e ocuparam parte importante do questionário respondido pelos delegados.

No que diz respeito a avaliações e propostas que têm sido feitas nas esferas do Poder Executivo e Legislativo, vale lembrar antes de tudo que o problema da Segurança Pública reveste-se de caráter especial, por sua relação com a dimensão federativa do Estado brasileiro. Embora o aparato policial do país esteja majoritariamente sob a responsabilidade dos governos estaduais (com exceção da Polícia Federal), os princípios que regem as polícias civil e militar, bem como a legislação que regula sua atuação cotidiana, estão definidos nacionalmente na Constituição Federal e por meio de leis específicas do Congresso Nacional. Nesse sentido, a

${ }^{3}$ Ver Mariano, Bicudo e Telles Júnior (2000). 
tentativa de reformar tais instituições ou mesmo a implementação de programas emergenciais de curto prazo, com vistas à redução da criminalidade e da violência, são tarefas difíceis e complexas, que requerem um amplo consórcio de vontades envolvendo entes federais e estaduais.

Nos últimos anos, o governo federal tem buscado estabelecer, por meio de planos nacionais, diretrizes de atuação e também de reforma do sistema de Segurança Pública. Nesse sentido, em 1997, o Programa Nacional de Direitos Humanos (PNDH), formulado pelo Executivo federal, destacou a importância das ouvidorias de polícia, propondo seu fortalecimento, inclusive com a participação de representantes da sociedade civil e com autonomia para realizar investigação nos casos levados a seu conhecimento. Compuseram também as metas do PNDH e foram de alguma forma incorporadas pelo nosso questionário incentivar "a criação e o fortalecimento das corregedorias de polícia, com vistas a limitar abusos e erros em operações policiais e emitir diretrizes claras a todos os integrantes das forças policiais com relação à proteção dos direitos humanos", "estimular programas de cooperação e entrosamento entre policiais civis e militares e entre estes e o Ministério Público" e "regulamentar o artigo 129, VII, da Constituição Federal, que trata do controle externo da atividade policial pelo Ministério Público" (proposta também defendida pelas ouvidorias, como vimos). Quanto a essa polêmica função do Ministério Público, cabe destacar que o Programa Estadual de Direitos Humanos do governo de São Paulo, apresentado em junho de 1997, também trazia como uma de suas propostas consolidar e fortalecer o controle externo da atividade policial pelo Ministério Público de acordo com o artigo 127, VII, da Constituição Federal de 1988.

Outra proposta presente no Plano Nacional de Direitos Humanos, e abordada pela pesquisa, é a transferência, da Justiça estadual para a Justiça federal, da competência de julgamento de crimes praticados em detrimento de bens ou interesses sob a tutela de órgão federal de proteção a direitos humanos. Apresentada pela primeira vez pelo governo federal em 1996, a ideia de "federalização dos crimes contra os direitos humanos" passou a integrar posteriormente também o Projeto de Emenda Constitucional 96/92, relativo à reforma do Judiciário, já aprovado pela Câmara dos Deputados e aguardando atualmente a votação no Senado ${ }^{4}$.

Com o agravamento da violência e da criminalidade, sobretudo nos grandes centros urbanos, o governo federal lançou em junho de 2000 o Plano Nacional de Segurança Pública, estabelecendo um conjunto de compromissos que deveriam ser assumidos em cooperação com os governos estaduais e com o objetivo de aperfeiçoar o sistema de segurança pública, por meio de medidas específicas, porém associadas a políticas sociais e a ações comunitárias.

Boa parte desses compromissos foi incorporada ao questionário e submetida à apreciação dos delegados de polícia, tais como:

- O compromisso $\mathrm{n}^{\mathbf{0}} 1$ que trata do combate ao narcotráfico e ao crime organizado, pelas polícias Federal, Rodoviária Federal, Civil e Militar estaduais. Esse mesmo compromisso prevê a modernização da Academia Nacional de Polícia a fim de incrementar a capacitação do policial, o que permitiria corrigir eventual deficiência de formação como foi mencionado em perguntas específicas do questionário.

- O compromisso $\mathrm{n}^{\mathrm{o}} 2$, sobre desarmamento e controle de armas, que especificou como um de seus objetivos o recadastramento $e$ a intensificação da fiscalização das empresas de segurança privada.

- O compromisso $\mathrm{n}^{\circ}$ 7, que trata da redução da violência urbana e prevê, entre outras ações, apoio para a integração das polícias civil e militar e implementação de conselhos comunitários de segurança pública.

- O compromisso $\mathrm{n}^{\mathbf{0}} 12$, que trata da capacitação profissional e o reaparelhamento das polícias, dando ênfase à capacitação das polícias estaduais, incentivo à implementação de polícias comunitárias, instalação de ouvidorias de polícia e criação de mecanismos de controle

\footnotetext{
${ }^{4}$ O PEC 96/92 estabelece que, nas "hipóteses de grave violação de direitos humanos, o Procurador-geral da República, com a finalidade de assegurar o cumprimento de obrigações decorrentes de tratados internacionais de direitos humanos dos quais o Brasil seja parte, poderá suscitar, perante o Superior Tribunal de Justiça, em qualquer fase do inquérito ou processo, incidente de deslocamento de competência para a Justiça Federal".
} 
das atividades da polícia por órgãos especiais e pelo Ministério Público, tópicos abordados pelo questionário por meio de perguntas específicas.

Passados dois anos da publicação do Plano Nacional de Segurança Pública, o governo já promoveu várias alterações em seu texto. A cada crime ou caso de violência de grande repercussão na opinião pública, o governo veio redefinindo suas metas e lançando novas versões ou ajustes do Plano. Uma dessas situações teve início com a morte do prefeito de Santo André, Celso Daniel, em janeiro de 2002, que acabou levando o próprio governo federal a reconhecer que, dos 124 itens do programa, oitenta não eram passíveis de execução imediata ou mesmo de pouca eficácia no curto prazo $^{5}$. Ao rever as metas, o Ministério da Justiça passaria a dar prioridade a três pontos, também abordados em perguntas do nosso questionário: a unificação dos comandos das instituições policiais estaduais, o combate à corrupção dentro das polícias e a criação da polícia comunitária.

No âmbito legislativo, a discussão sobre a crise da Segurança Pública também se avolumou nos últimos anos e são vários os projetos de lei que tramitam hoje no Congresso Nacional e que podem vir a afetar o funcionamento da polícia brasileira. Entre mudanças na legislação penal, nos sistemas judiciário e prisional e na polícia, havia 245 propostas de alteração legislativa tramitando no Congresso Nacional em fevereiro de $2002^{6}$. Em março, a Câmara dos Deputados criou a Comissão Permanente de Segurança Pública e Combate ao Crime Organizado, Violência e Narcotráfico (passando a integrar o Regimento Interno da Casa) para dar tratamento mais efetivo a essas questões e principalmente racionalizar a tramitação de projetos de lei marcados hoje por elevado grau de diversidade e até mesmo de contradição entre si, no âmbito do Legislativo federal.

Tramitam atualmente no Congresso Nacional projetos como os da criação da Guarda Nacional (PEC 87/99) e da polícia penitenciária (PEC 219/00), da obrigatoriedade de avaliação psicológica periódica dos integrantes das polícias Civil e Militar (PLC 21/97), até a atribuição de exclusividade à Polícia Federal da função de repressão ao tráfico de drogas

\footnotetext{
${ }^{5}$ O Estado de S. Paulo, 29 jan. 2002, "Governo Vai Mudar Plano de Segurança de Novo”.

${ }^{6}$ Segundo triagem feita pela comissão especial formada por deputados e senadores, instalada em fevereiro de 2002 e destinada a elaborar o pacote antiviolência. Ver $O$ Estado de $S$. Paulo, 19 fev. 2002, "Comissão Começa a Preparar Pacote Contra a Violência".
}

(PEC 207/00), passando pela obrigatoriedade do delegado de informar as vítimas de estupro sobre o direito ao aborto legal (PL 605/99), apenas para citar exemplos isolados de projetos que afetam diretamente o funcionamento da polícia.

Em termos mais agregados, pode-se dizer que há três grandes frentes de reforma hoje no Congresso Nacional e que, se levadas adiante, terão consequências importantes para o desempenho da atividade policial no Brasil: a) a reforma do Código do Processo Penal (PLs 203 a 210); b) a reforma do Sistema de Segurança Pública (PEC 151/95); e c) a elaboração das leis orgânicas da Polícia Civil (PL 3274/00) e da Polícia Militar (4363/01). Delas, procuramos extrair alguns pontos polêmicos que foram submetidos, por meio do questionário, à apreciação dos delegados de policia.

As propostas elaboradas pela comissão responsável pela reforma do Código do Processo Penal ${ }^{7}$ foram encaminhadas ao Congresso Nacional em março de 2001, por meio de oito projetos de lei (do PL 4.203 ao 4.210), tratando desde o inquérito policial até o funcionamento do Tribunal do Júri. Desses, apenas o PL 4.210, relativo à redução de regalias da prisão especial, foi transformado em lei (Lei 10.258/01), assunto este que mereceu pergunta específica no questionário. Embora o PL 4.210 não tenha removido o privilégio da prisão especial, cabe registrar que existem hoje no Congresso mais de uma dezena de projetos sobre essa questão, alguns extinguindo o tratamento diferenciado e outros o estendendo a outras categorias como os integrantes das guardas municipais ${ }^{8}$.

Entretanto, de todos os projetos relativos à reforma do $\mathrm{CPP}$, o mais importante para os delegados de polícia é o PL 4.209, que trata do inquérito policial. Como procedimento, o inquérito policial vem sendo apontado como causa da morosidade, da ineficiência e até mesmo como facilitador da corrupção na esfera policial. Muitos têm defendido sua extinção e substituição por outra forma de registro, investigação e apuração de fatos criminosos. A hipótese de extinção do inquérito policial é vista com receio

${ }^{7}$ A Comissão, instalada em fevereiro de 2000, foi coordenada por Ada Pellegrini Grinover e pelo Promotor de Justiça Petrônio Calmon Filho, e integrada por Miguel Reali Júnior, Antônio Magalhães Gomes Filho, Antônio Scarance Fernandes, Luiz Flávio Gomes, Nilzardo Carneiro Leão, Rene Anel Dotti, Rogério Lauria Tucci e Sidnei Benneti.

${ }^{8}$ Ver Folha de S. Paulo, 17 jan. 2001, p. A-4. 
pelos delegados de polícia, justamente porque o controle desse instrumento é o que lhes confere status diferenciado. No sistema penal brasileiro, o inquérito está para o delegado assim como a ação penal pública está para o promotor de justiça e o processo está para o juiz. Em que pese haver momentos de interferência de uns sobre os outros, pode-se dizer que são peças, funções e etapas distintas, que garantem a cada um dos agentes reserva de espaço institucional, prerrogativas e garantias no desempenho de suas atribuições. A preocupação dos delegados de polícia com mudanças no inquérito policial faz sentido do ponto de vista do risco de esvaziamento do cargo, dadas as alternativas de substituição comumente aventadas: o controle e a produção direta da investigação pelo Judiciário ou pelo Ministério Público.

Desde o início dos trabalhos da comissão de reforma do CPP, a questão do inquérito policial foi objeto de intensa polêmica e houve quem defendesse a criação do chamado juizado de instrução como fórmula de melhorar a fase preliminar - investigatória - da persecução criminal. Outros propuseram a direção dos trabalhos de investigação policial pelo Ministério Público. No final, a comissão decidiu manter a figura do inquérito policial, sob direção do delegado de policia, mas reafirmou e ampliou as hipóteses de acesso e controle da fase inquisitorial pelo Ministério Público, apoiada no princípio constitucional do "controle externo da atividade policial pelo Ministério Público". Todas essas hipóteses de mudança em torno da investigação e instrução no processo criminal foram abordadas pelo questionário submetido aos entrevistados.

A segunda frente de reforma existente no Congresso Nacional gira em torno do Proposta de Emenda à Constituição 151/95. Essa PEC se destina a modificar o artigo $144^{9}$ da Constituição Federal, que trata justamente da Segurança Pública. Apensadas à PEC 151/95 estão hoje:

- A PEC 156-A/95, que trata da transferência dos policiais federais da RFFSA (Rede Ferroviária Federal S.A.) e da CBTU (Companhia

\footnotetext{
${ }^{9}$ Diz o artigo 144 da CF: "A segurança pública, dever do Estado, direito e responsabilidade de todos, é exercida para a preservação da ordem pública e da incolumidade das pessoas e do patrimônio, através dos seguintes órgãos: I - polícia federal; II - polícia rodoviária federal; III - polícia ferroviária federal; IV - polícias civis; V - polícias militares e corpos de bombeiros militares".
}

Brasileira de Trens Urbanos) do Ministério dos Transportes para o Ministério da Justiça.

- A PEC 514-A197, encaminhada pelo Poder Executivo na dramática época da explosão de greves das polícias militares em alguns estados, traz como principal proposta a desconstitucionalização dos órgãos de Segurança Pública, deixando aos estados a faculdade de legislar sobre eles, além da proibição da sindicalização, da greve e de atividades político-partidárias dos servidores desses órgãos.

A PEC 613-A198, a mais ampla de todas e que tenta abranger globalmente o sistema de segurança pública, incluindo a unificação das polícias, a desmilitarização dos corpos de bombeiros, a criação de vedações e garantias dos servidores da segurança pública, a ampliação das funções das guardas municipais e a criação da guarda nacional, além da extinção da justiça militar estadual, entre outras mudanças.

A Comissão Especial que analisou a PEC 151/95 encerrou os trabalhos aprovando, com modificações, a proposta apresentada pelo relator, deputado Alberto Fraga (PMDB-DF), coronel da Polícia Militar, presidente do Clube dos Oficiais da PM do Distrito Federal e figura atuante em questões de segurança e na defesa dos interesses da corporação militar. O projeto de reforma do sistema de Segurança Pública, que aguarda hoje votação pelo plenário da Câmara dos Deputados, foi duramente criticado por diversos segmentos, desde a Associação dos Delegados de Polícia do Brasil (Adepol$\mathrm{BR}$ ) até a Comissão de Direitos Humanos da própria Câmara.

Algumas mudanças promovidas pela PEC 151/95 integraram o questionário submetido aos delegados de polícia, como as já mencionadas unificação das polícias Civil e Militar, a criação do juizado de instrução, o fortalecimento (pela via da constitucionalização) das ouvidorias de polícia, a criação da perícia oficial como carreira independente e outras como a criação de um conselho de controle externo da atividade policial, em substituição à fórmula atual que delega essa função ao Ministério Público. Esse conselho seria formado com base em critérios de representação semelhantes aos aventados para os órgãos de controle da Magistratura e do Ministério Público, em discussão no âmbito da reforma do Judiciário. 
Apesar de conter aspectos que se aproximam da visão dos órgãos governamentais e entidades da sociedade civil ligados à defesa dos direitos humanos, tais como a unificação/fusão das polícias e a criação de mecanismos de controle externo, a PEC 151/95 também foi criticada por esses segmentos, entre outras coisas por propor a desconstitucionalização da maioridade penal, deixando à lei infraconstitucional a definição de um novo limite e abrindo com isso a possibilidade de redução dessa faixa etária, que hoje é de 18 anos (assunto também abordado no questionário).

Embora a PEC 151/95 eleve a polícia à condição de órgão "essencial à função da justiça", introduzindo uma nova seção no capítulo IV do Título IV da CF, ao lado do Ministério Público (seção I), da Advocacia Geral da União (seção II) e da Advocacia e Defensoria Pública (seção III) e estabeleça vedações, garantias e privilégios semelhantes aos existentes para a Magistratura e Ministério Público, a proposta não agradou às associações de delegados, que a tomaram como um ataque direto à Polícia Civil. Assim se manifestou o presidente da Adepol-BR sobre o projeto e, especialmente, sobre o relator, deputado Alberto Fraga, a quem considerou "adversário gratuito e contumaz" da Polícia Civil:

Em face não só da origem do Senhor Relator, coronel da Polícia Militar do Distrito Federal - como também do profundo ressentimento que nutre pela Polícia Civil do Brasil, principalmente porque dirigidas por bacharéis em direito e integrantes de sólidas carreiras, portanto, com atuação profissional independente, suas conclusões não têm sido de nosso agrado, especialmente por falta de coerência prática e jurídica, sempre dissociadas da nossa realidade cultural e dos sentimentos de um ideal de justiça e de cidadania ${ }^{10}$.

Em meio à baixa aceitação da PEC 151/95 e à crise suscitada pela morte do prefeito Celso Daniel, o Partido dos Trabalhadores apresentou ao Congresso Nacional, em fevereiro de 2002, uma outra Proposta de Emenda

10 Jair Cesário da Silva, presidente da Adepol-BR, em editorial no informativo da Associação, do mês de maio de 2001. No informativo de junho, Jair Cesário voltaria à carga: "Acrescente-se ainda que é desejo das lideranças dos partidos no Congresso Nacional de se criar uma Comissão Permanente para Assuntos de Segurança Pública e se esta medida se efetivar, todos os assuntos dessa natureza serão avocados, terminando aí, a aventura publicitária do deputado Alberto Fraga para alívio de todos nós". Ver sítio da Adepol na internet: http://www.adepoldobrasil.com.br.
Constitucional (PEC 496/02). A proposta do partido prevê a integração completa das polícias Civil e Militar e a criação de uma polícia estadual responsável pelas funções de polícia judiciária, apuração das infrações penais e policiamento ostensivo urbano e rural. De acordo com o PT, caberia ao Ministério Público a condução da investigação policial, com a colaboração da polícia judiciária; as ouvidorias de polícia seriam transformadas em órgãos permanentes da segurança pública e os institutos de criminalística, médico-legal e de identificação tornar-se-iam independentes da Polícia Civil, ficando vinculados às secretarias de segurança pública. O projeto do PT prevê ainda a criação de conselhos estaduais e municipais de segurança pública, que teriam como função o controle externo da atividade policial. Tais temas e propostas também foram levados à apreciação dos delegados, por meio do questionário.

Mais do que reduzir divergências em relação ao novo modelo de polícia que se quer instalar no Brasil, o grande desafio da reforma do sistema de segurança pública será equacionar regras de transição de um modelo a outro, de maneira que os agentes do sistema atual sejam levados a uma ação cooperativa rumo à introdução do novo sistema.

Talvez seja essa a razão da existência de diversas frentes de reforma legislativa, impulsionadas pelos diversos agentes em disputa e, enquanto nenhuma das propostas conseguir equacionar uma fórmula razoável de transição, os interesses segmentados se digladiarão num movimento de proposições e vetos sem resultados concretos no curto prazo. Nesse sentido, uma terceira e importante frente de reforma legislativa existente na Câmara, e que em vários pontos sobrepõe-se às demais, diz respeito à Lei Orgânica da Polícia Civil, cujo projeto de lei foi apresentado primeiramente em 1993 (PL 4.371) e recebeu novo impulso quando a ele foi apensado o PL 3.274/00, de autoria do Poder Executivo e enviado ao Congresso em 2000, inclusive com pedido de urgência.

O projeto de Lei Orgânica da Polícia Civil, também mencionado em item específico do nosso questionário, tem sido defendido fortemente pelas associações de delegados de polícia, paralelamente aos demais projetos de 
reforma da Segurança Pública ${ }^{11}$. Pelo menos enquanto a reforma estrutural das polícias não avançar, o PL 3.274/00 é e será a principal bandeira da Polícia Civil, pelas conquistas que pode significar para a corporação ${ }^{12}$. Diferentemente das demais frentes de reforma legislativa, o PL 3.274 não propõe alteração radical na estrutura do aparato policial brasileiro, apenas estabelece "normas gerais de organização da Polícia Civil e as garantias, direitos e deveres dos policiais civis", que por sua vez teriam de ser suplementadas por legislação estadual específica.

Nesse sentido, a última versão do PL 3.274/00, na forma do substitutivo apresentado pelo deputado Antonio Carlos Pannunzio (PSDBSP), não altera significativamente a organização e as atribuições da Polícia Civil e, no que diz respeito a pontos polêmicos como a questão do inquérito policial ou a relação da instituição com o Ministério Público, o substitutivo parece adotar a perspectiva da corporação. Para citar um exemplo, o artigo $3^{\circ}$ do projeto estabelece que "as funções constitucionais das polícias civis somente poderão ser desempenhadas por ocupantes das carreiras que a integram", o que constitui dispositivo legal claramente destinado a afastar outras instituições da possibilidade de conduzir a investigação criminal fora do inquérito policial (como vem fazendo atualmente, em diversos casos, o Ministério Público).

Por outro lado, como se trata de projeto de lei orgânica de uma instituição específica, dimensões estruturais do sistema de segurança pública não foram contempladas no projeto, embora o próprio relator da matéria tenha reconhecido a dificuldade de lidar com a organização da Polícia Civil isoladamente:

Desconsiderar o sistema existente, com a sua distribuição expressa de competências, seria, também, fonte de redução de eficácia da norma e, mais do que isso, transformação da Lei Orgânica das Polícias Civis em foco de discórdias e conflitos entre este órgão de segurança

\footnotetext{
${ }^{11}$ Viemos acompanhando desde 2001 as manifestações públicas dessas associações e seus dirigentes nos congressos da categoria, por meio de revistas e outras publicações próprias, além dos pronunciamentos que fazem na imprensa e em audiências públicas no Congresso Nacional. ${ }^{12}$ Cabe registrar que a Ouvidoria de Polícia de São Paulo também considera fundamental a promulgação da "Lei Orgânica da Polícia Civil", mas com o objetivo de criar um regulamento disciplinar mais ágil e fortalecer a hierarquia policial (ver Ação Propositiva 5 da Ouvidoria de Polícia de São Paulo).
}

pública e o órgão estadual responsável pela polícia ostensiva e pela preservação da ordem pública - a polícia militar (Pannunzio, 2002).

A observação do debate público em torno das propostas de mudanças legislativas nos permitiu perceber como as associações de delegados de polícia de vários estados e especialmente a entidade que atua no nível nacional - Adepol-BR - têm desempenhado importante papel na formulação de propostas de reforma do sistema de segurança pública e, nesse sentido, suas manifestações públicas constituíram fonte importante de informação na elaboração do questionário. A participação dessas associações tem sido marcada não só pela apresentação de medidas que visam melhorar globalmente o desempenho do sistema, mas principalmente pela preocupação em preservar determinadas prerrogativas da corporação, no processo de transição para um eventual novo modelo de polícia. Assim ficou evidente quando, desde o início das discussões sobre a reforma do Código de Processo Penal, a Associação de Delegados de Polícia de São Paulo saiu em defesa do inquérito policial como instrumento de responsabilidade exclusiva da autoridade policial - o delegado de polícia - e condenou a intervenção do Ministério Público nas atividades da Polícia Civil.

A "Carta de Goiânia", resultado de debates ocorridos em fevereiro de 2000 na cidade de Goiânia, também é um importante exemplo que sinaliza a posição assumida pela Adepol-BR diante das discussões sobre a reforma do Código de Processo Penal. Nesse documento, os delegados defenderam a preservação do inquérito policial como responsabilidade da Polícia Civil e acusaram de indevida a interferência do Ministério Público na atividade policial, por ferir o princípio da igualdade das partes: se o Ministério Público é o titular da ação penal e, portanto, parte interessada no processo, ele estaria impedido de assumir o controle da investigação, sob o risco de perda de isenção caso acumulasse as duas funções (as difíceis relações da Polícia Civil com o Ministério Público foram abordadas em vários pontos do questionário).

Por outro lado, os delegados têm se empenhado pela aprovação do PL 3.274/00, pelas garantias e direitos que traz à corporação. Em seu último congresso nacional, por meio da "Carta de Rio Quente", os delegados de polícia exortaram os líderes dos partidos políticos a "prosseguirem com a 
tramitação, até a aprovação final, do projeto de Lei Orgânica da Polícia Civil" (PL 3.274/00) ${ }^{13}$.

Foi justamente da junção de elementos constantes do PL 3.274/00 com alguns outros defendidos pela Adepol-BR sobre a organização policial, que partimos para elaborar algumas perguntas do questionário. Assim, a Adepol-BR defende e o PL 3.274/00 reafirma a exclusividade da Polícia Civil e dos delegados em particular sobre a instauração dos inquéritos policiais e a direção dos trabalhos de investigação, contra as investidas recentes do Ministério Público nessa área. A Associação também defende outros pontos que constam do referido projeto, tais como: a permanência da vinculação de órgãos técnicos (IML e Perícia) à Polícia Civil, pelo menos nos estados nos quais a Constituição Estadual não lhes atribui independência (art. $7^{\circ}$, inc. VII do PL 3.274/00); a escolha do Delegado Geral pelo governador do estado, em fórmula a ser estabelecida por lei específica (art. $8^{\circ}$ do PL 3.274/00), a permanência da Corregedoria da Polícia como órgão integrante da carreira (seção VI do PL 3.274/00) e com competência exclusiva no controle e punição dos policiais civis, afastando hipóteses alternativas como a criação de um órgão de controle externo ou a fiscalização da atividade policial pelo Ministério Público; a adoção de medidas para melhorar o nível da formação dos integrantes da Polícia Civil, tais como a consideração, para efeito de classificação geral no concurso de ingresso nas carreiras policiais, de diploma em curso de graduação na área de segurança pública (art. $7^{\circ}, \S 3^{\circ}$ do PL 3.274/00), e o estabelecimento de competências para os órgãos de formação e capacitação da Polícia Civil (art.14 do PL 3.274/00). Cada um destes tópicos mereceu item específico em nosso questionário.

Embora esteja dando prioridade à aprovação da Lei Orgânica da Polícia Civil, a Adepol-BR ${ }^{14}$ não deixou de se manifestar sobre os projetos relativos ao sistema de segurança pública, em tramitação no Congresso Nacional. Como vimos, foi alto o grau de discordância que a Associação manteve com a Comissão Especial encarregada da PEC 151/95, especialmente

\footnotetext{
13 "Carta do Rio Quente", XI Congresso Nacional de Delegados de Polícia de Carreira, realizado na Pousada do Rio Quente, em Caldas Novas (GO), entre 16 e 19 de setembro de 2001.

${ }^{14}$ Informações importantes utilizadas aqui foram obtidas no sítio da Adepol na internet, http://www.adepoldobrasil.com.br.
}

do relatório apresentado pelo deputado Alberto Fraga. Além disso, a AdepolBR formulou uma proposta de emenda constitucional, cujo aspecto mais importante a ser destacado é a previsão de regras de transição do sistema atual para o modelo novo de uma polícia unificada, incluindo a realocação de policiais e oficiais da Polícia Militar e agentes da Polícia Civil, com atenção especial para os delegados de polícia, que passariam a ser denominados de "autoridades policiais" e exerceriam a função de direção da nova polícia.

$\mathrm{O}$ projeto formulado pela Adepol-BR procura ainda modificar a Constituição de 1988 em alguns pontos considerados cruciais para o bom funcionamento da atividade policial no Brasil. Como exemplos, podem ser mencionados mais uma vez a problemática relação da polícia com o Ministério Público e a questão do mandado de busca e apreensão. Quanto ao primeiro, diz a Adepol-BR que os constituintes de 1988 enganaram-se quando

[...] estabeleceram o controle externo da atividade policial nos termos preconizados no Art. 129, inc. VII, da Lei Magna, confiando-o ao Ministério Público. Não que o aparelho policial deva prescindir de um controle externo. Não é isso! Mas esse controle não deveria estar a cargo de uma única instituição, máxime quando ela é reconhecidamente adversária da polícia, principalmente das autoridades policiais, propugnando pela direção das atividades de polícia judiciária no que concerne à apuração das infrações penais. Esse controle não pode ser hermético, fechado, praticado por uma instituição em outra, com reais possibilidades de descambar para a tentativa de imposição hierárquica - como, aliás, sói acontecer em quase todo território nacional - própria do controle interno da polícia, de responsabilidade das autoridades mais graduadas na linha hierárquica da instituição. Ele deve ser aberto, democrático, realizado por um colegiado onde participassem membros do Ministério Público, do Judiciário, da OAB, da sociedade organizada e da própria polícia, para que ele possa cumprir suas reais finalidades e não servir apenas de poleiro para as vaidades ocas de alguns radicais do órgão ministerial ${ }^{15}$.

Quanto à possibilidade de o delegado de polícia voltar a fazer busca domiciliar sem mandado judicial (último dos temas abordados nessa parte do questionário), assim se manifesta a Adepol-BR, na apresentação de sua proposta de reforma constitucional:

${ }^{15}$ Ver sítio da Adepol-BR, http://www.adepoldobrasil.com.br/diversos/pro posta.doc. 
[...] os constituintes de 1988, a nosso ver, equivocaram-se ao não mais permitir a diligência de busca e apreensão domiciliar por ordem da própria autoridade policial. Hoje, à luz da norma consubstanciada no Art. $5^{\circ}$, inc. XI, essa importantíssima atividade das polícias civis depende de determinação judicial. Despiciendo argumentar as razões que nos levam a entender equivocada a decisão dos legisladores constituintes, basta verificar como dificultou o mister policial na repressão aos crimes de furto, roubo, roubo seguido de morte (latrocínio), tráfico ilícito de entorpecentes etc. ${ }^{16}$.

Em suma, no que diz respeito ao processo de reforma do sistema de segurança pública, é notável a sobreposição de projetos em tramitação no Congresso Nacional e há fortes indícios de que, no estágio em que se encontram, refletem muito mais a falta de consenso sobre a direção geral da reforma, bem como a atuação estratégica dos atores interessados, no âmbito das comissões e do processo legislativo, nessa fase ainda preliminar de elaboração de um novo projeto para a área.

PROBLEMAS DE FUNCIONAMENTO E PROPOSTAS DE REFORMA DA POLÍCIA, DA SEGURANÇA PÚBLICA E DO SISTEMA PENAL, SEGUNDO OS DELEGADOS DE POLÍCIA

Esta seção apresentará os resultados do survey no que diz respeito às perguntas relativas aos quatro eixos apresentados na introdução deste capítulo, em torno dos quais tem se dado o debate público descrito na seção anterior.

Pelo Gráfico 1, podemos perceber como os delegados entrevistados posicionaram-se a respeito dos principais obstáculos ao bom funcionamento da Polícia Civil no Brasil.

Assemelhando-se à tendência revelada em pesquisas anteriores do Idesp, nas quais juízes e membros do Ministério Público responsabilizaram instituições externas ao sistema judicial pela crise da justiça, também entre os delegados é forte a ideia de que as deficiências que afetam o desempenho da polícia têm causas externas que parecem fugir ao controle direto da instituição.

\footnotetext{
${ }^{16}$ Idem.
}

\section{GRÁFICO 1: OBSTÁCULOS AO BOM FUNCIONAMENTO DA POLÍ́CIA CIVIL}

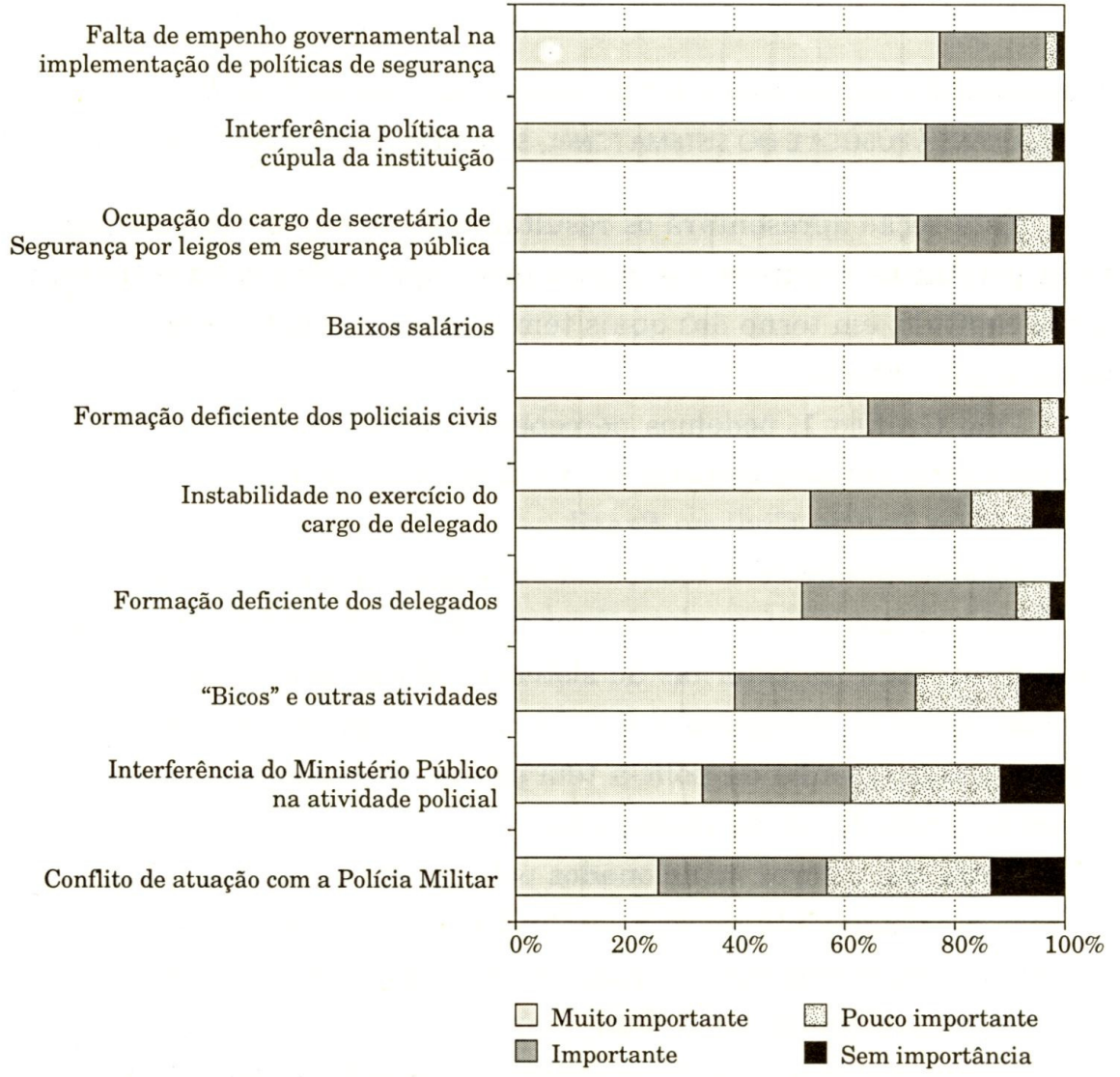

TEXTO DA PERGUNTA $\mathbf{N}^{\circ}$ 23: "Na sua opinião, qual a importância dos seguintes fatores como obstáculos ao bom funcionamento da Polícia Civil?"

Obs.: Excluídos os que não responderam e os que assinalaram não ter opinião. Nessa pergunta, em média, 3,6\% dos entrevistados não responderam ou assinalaram não ter opinião sobre os itens mencionados.

Entre dez fatores mencionados pelo questionário como obstáculos ao bom funcionamento da Polícia Civil, a "falta de empenho governamental na implementação de políticas de segurança" foi apontada por $95 \%$ dos entrevistados como fator "importante" ou "muito 
importante", encabeçando assim a lista de problemas mais graves que afetam a atividade policial. Em seguida, e dentro da mesma tendência de externalizar as causas do mau funcionamento da polícia, 90\% dos delegados consideraram a "interferência política na cúpula da instituição" como obstáculo "importante" ou "muito importante".

Em outras palavras, a opinião dos entrevistados sugere uma combinação perversa de duas condutas políticas aparentemente contraditórias mas que trazem grave prejuízo à instituição: o mesmo poder político que não dá a devida atenção ao desenvolvimento de um adequado sistema de Segurança Pública é aquele que interfere politicamente na cúpula da instituição, comprometendo o seu funcionamento ideal. Essa opinião é avalizada pelas frequentes declarações dos órgãos de representação da carreira e, mais especificamente, da Associação dos Delegados de Polícia do Estado de São Paulo (ADPESP). Paulo Fernando Fortunato, presidente da associação, em seu discurso de posse em dezembro de 1999, afirmou: "A Polícia Civil não está servindo com eficiência porque foi imobilizada de forma proposital [...] com humilhações e descaso governamental, insensível às ponderações apresentadas por esta entidade de classe" ${ }^{\text {"17 }}$.

A avaliação de que a interferência política fragiliza a Polícia Civil parece estar associada ao problema do baixo grau de insulamento institucional, do qual se ressentem os Delegados. Nesse sentido, $89 \%$ dos entrevistados apontaram como obstáculo "importante" ou "muito importante" a "ocupação do cargo de Secretário de Segurança por leigos em segurança pública", fato comum nos estados em que o governador não encontra um nome de confiança na polícia ou por outros motivos decide chamar alguém estranho aos órgãos de segurança.

A questão política associada à falta de autonomia da polícia reflete-se também na crítica ao problema dos "baixos salários", motivo de recentes movimentos grevistas, paralisações e tumultos graves envolvendo policiais civis e militares em vários estados brasileiros. Esse problema foi considerado pelos entrevistados como o terceiro obstáculo mais importante ao bom funcionamento da Polícia Civil.

\footnotetext{
${ }^{17}$ Ver ADPESP (2000, p.9).
}

Embora tenha recebido um peso menor, comparativamente a outros fatores, a "instabilidade no exercício do cargo de delegado" foi apontada como fator "importante" ou "muito importante" por nada menos do que $81 \%$ dos entrevistados.

Dentre os fatores que dividiram um pouco a opinião dos entrevistados, a "interferência do Ministério Público na atividade policial" foi considerada obstáculo importante por $61 \%$ dos delegados (somadas as respostas "importante" e "muito importante") ao passo que 38,9\% afirmaram o contrário (somadas as respostas "pouco importante" e "sem importância"). Teste estatístico ${ }^{18}$ revelou diferenças significativas entre os estados: os delegados do Nordeste destacaram-se mais do que os outros por entenderem que esse não é um obstáculo importante, ao passo que seus colegas do Centro-Oeste afirmaram em número proporcionalmente maior que essa interferência é um obstáculo importante ao bom funcionamento da Polícia Civil. Além da dimensão regional, a dimensão ideológica também teve impacto significativo nas respostas a esse item, em termos estatísticos: os delegados que se localizaram à direita no espectro ideológico consideraram a interferência do Ministério Público na atividade policial um importante obstáculo ao bom funcionamento da Polícia Civil, mais do que seus colegas de esquerda, que tendem a aceitar mais facilmente essa interferência e não a consideraram um obstáculo tão importante.

Em consonância com o diagnóstico sobre os principais problemas que afetam o funcionamento da Polícia Civil - especialmente seu baixo grau de institucionalização e autonomia -, a proposta que recebeu mais apoio dos delegados, segundo o Gráfico 2, foi justamente a "promulgação da Lei Orgânica Nacional da Polícia Civil" (96\% de respostas afirmativas, somandose "importante" e "muito importante"). Esse resultado coincide com o empenho que as associações de delegados têm tido na defesa da aprovação do Projeto de Lei no 3.274/00 - Lei Orgânica Nacional da Polícia Civil - em tramitação no Congresso Nacional.

\footnotetext{
${ }^{18}$ No que diz respeito a este e aos próximos conjuntos de resultados apresentados, utilizamos o teste estatístico de independência entre variáveis chi-quadrado, com os chamados "resíduos ajustados" por célula, que nos permitiram verificar a contribuição de cada célula para a associação estatística entre variáveis encontrada na tabela. Por economia de texto, sempre que se fizer referência a teste estatístico, é a este que estamos nos referindo.
} 
GRÁFICO 2: PROPOSTAS PARA MELHORAR O FUNCIONAMENTO DA POLÍCIA CIVIL

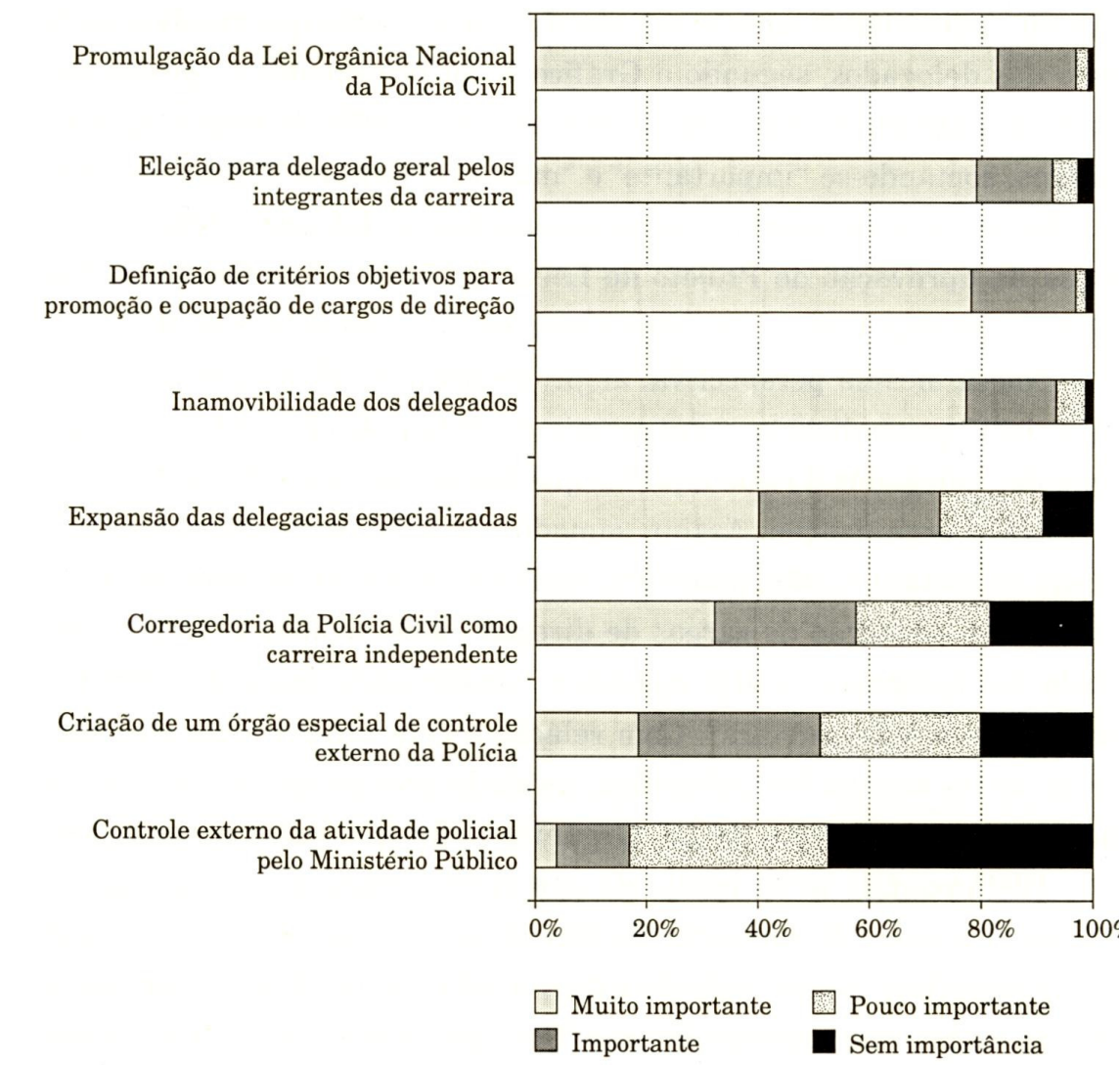

TEXTO DA PERgunTA No 24: “Que peso o Sr. (a) atribui às seguintes propostas para melhorar o funcionamento da Polícia Civil?”

Obs.: Excluídos os que não responderam e os que assinalaram não ter opinião. Nessa pergunta, em média, 2,6\% dos entrevistados não responderam ou assinalaram não ter opinião sobre os itens mencionados.

Nessa mesma perspectiva, as propostas específicas que implicam maior institucionalização e autonomia da Polícia Civil receberam mais apoio dos delegados do que aquelas que implicam maior controle externo sobre a organização. Assim, somadas as respostas "importante" e "muito importante", 96\% apoiam a "definição de critérios objetivos para promoção e ocupação de cargos de direção", 93\% apoiam a "inamovibilidade dos delegados" e $91 \%$ apoiam a "eleição para delegado geral pelos integrantes da carreira". Com relação a esta última proposta, apesar do apoio maciço dos delegados, revelado pela pesquisa, ela não foi encampada pelo Projeto de Lei Orgânica defendido pelas associações.

Distanciando-se da média de aprovação dessas propostas, aparecem as sugestões de melhoria do funcionamento da Polícia Civil que podem significar maior controle externo sobre a instituição: por maiorias apertadas, as propostas de uma "Corregedoria da Polícia Civil como carreira independente" e de "criação de um órgão especial de controle externo da polícia" são apoiadas respectivamente por $55 \%$ contra $40 \%$ e por $49 \%$ contra $46 \%$ dos entrevistados. Já a ideia de "controle externo da atividade policial pelo Ministério Público" foi rejeitada por 79\% e recebeu apoio de apenas $16 \%$ dos entrevistados.

A atuação da Corregedoria da Polícia Civil e do Ministério Público no controle da atividade policial é ponto de constante tensão entre as duas instituições. Um exemplo dessa tensão foi a crise recente, deflagrada pela atuação de policiais civis na região da "Cracolândia", na cidade de São Paulo. Durante 36 dias, sem conhecimento da polícia civil, o Ministério Público filmou a ação de policiais civis naquela região da cidade. A investigação levou à prisão temporária de cinco policiais do Denarc (Departamento de Investigações sobre Narcóticos) sob acusação de relações com o tráfico de drogas e o afastamento do então corregedor de polícia, delegado Rui Estanislau Silveira Mello, da direção da Corregedoria da Polícia Civil. De acordo com notícias divulgadas na época, o delegado Rui Estanislau teria se sentido traído pelo Ministério Público ao não ser informado sobre o início da apuração. Segundo ele, a corregedoria já investigava o grupo, mas preparava um flagrante. Nesse mesmo episódio, a Associação dos Delegados de Polícia de São Paulo manifestou seu apoio à corregedoria, classificando a atitude do delegado Rui Estanislau como "altiva, nobre, corajosa, desprendida e sobranceira", e que ele teria se 
afastado "para não se submeter ao constrangimento de trabalhar com um promotor que não o tratou com respeito e lealdade"19.

Ainda quanto a esse conjunto de propostas, é importante ressaltar que as associações dos delegados de polícia de vários estados, reunidas em Goiânia em fevereiro de 2000 para discutir a reforma do Código de Processo Penal, sustentaram a posição de que a fiscalização dos policiais civis cabe exclusivamente à Corregedoria da Polícia Civil, órgão integrante da estrutura da própria polícia civil, juntamente com o órgão de direção superior e o conselho superior. Reagindo às posições assumidas pela comissão que elaborou o anteprojeto de reforma, que previa um maior controle das atividades policiais pelo Ministério Público ou por um órgão externo a ser criado para essa função, os chefes de polícia e presidentes de associações e sindicatos de delegados de polícia, na "Carta de Goiânia", argumentam que "investigar e indiciar servidor policial é atribuição do órgão corregedor da instituição a que o mesmo pertence, tendo em vista tratar-se de matéria inerente a controle interno".

Teste estatístico revelou algumas diferenças significativas no que diz respeito a essas últimas propostas. Dentre os $16 \%$ de delegados que manifestaram apoio ao "controle externo da atividade policial pelo Ministério Público", os delegados de esquerda tiveram maior peso do que os de direita (o que reforça o resultado do Gráfico 1, pela qual os delegados de direita criticaram mais fortemente do que os demais a interferência do MP na atividade policial). Já no que se refere à "expansão das delegacias especializadas", os delegados de direita consideram a proposta importante, mais do que seus colegas de esquerda, que foram os principais responsáveis pelo grau de $27 \%$ de discordância em relação a essa ideia. Outro importante resultado estatístico sobre essa proposta revelou que os delegados que atuam nas capitais apoiam menos do que os demais essa expansão, ao passo que aqueles que atuam na região metropolitana reforçaram mais do que os outros o percentual geral de $73 \%$ de aprovação à ideia. Essa dimensão espacial também se revelou importante no que diz respeito à divisão de opiniões sobre a proposta de uma "Corregedoria da Polícia Civil como carreira independente": os delegados da capital foram os principais

\footnotetext{
${ }^{19}$ Ver Folha de S. Paulo, $18 \mathrm{dez} .2001$, p.C-4.
}

responsáveis pela rejeição da ideia ao passo que os delegados do interior foram os que mais reforçaram a importância da proposta.

Quanto a essa questão é importante lembrar que as corregedorias têm atuação restrita em vários estados. No estado de São Paulo, por exemplo, a Corregedoria da Polícia Civil vinha atuando apenas na capital e apenas em agosto de 2002 ela estendeu suas atividades ao interior do estado.

Com relação à divisão da opinião em torno da criação de um "órgão especial de controle externo da polícia" (49\% versus $46 \%$ ), teste estatístico revelou que a dimensão regional é variável importante nesse caso: os delegados do Amapá e dos estados do Sul são os que puxam para cima o percentual de aprovação da proposta, ao passo que os delegados dos estados do Sudeste são os principais responsáveis pela rejeição a essa ideia. Da mesma forma, os entrevistados no Sudeste recusam mais do que os outros a ideia de "controle externo da atividade policial pelo Ministério Público", ao passo que os delegados do Amapá e dos estados do Sul e do Nordeste tiveram peso especial na obtenção de $16 \%$ de aprovação a essa ideia.

Quanto às propostas para melhorar a segurança pública (Gráfico 3), 94\% dos entrevistados concordaram "em termos" ou "totalmente" com a "criação de grupos especiais na polícia para aumentar a eficiência do combate ao crime organizado". Esse número expressivo representa a aceitação, nem sempre usual, por parte dos delegados de alterar a estrutura policial existente. Esse tipo de reconhecimento só costuma ocorrer em situações graves, dado o receio que cerca a criação de grupos especiais que muitas vezes fogem ao comando hierárquico e caem nas armadilhas da corrupção.

Surpreendente é também o grau de preocupação que os delegados demonstraram em relação à segurança privada: nada menos do que $83 \%$ dos entrevistados concordaram "em termos" ou "totalmente" com a ideia de "maior fiscalização e controle sobre as empresas de segurança privada".

Nos últimos anos tornou-se comum a ideia de que a solução para a crise da segurança pública no Brasil passa necessariamente pela aproximação entre os organismos policiais e a comunidade, como forma de compensar o baixo grau de controle externo sobre as polícias, bem como facilitar o acesso da população aos instrumentos de prevenção e reparação do crime. A “implementação de conselhos comunitários de segurança 
pública" tem sido uma prática comum em vários estados e, pela pesquisa, recebe apoio de $83 \%$ dos delegados.

\section{GRÁFICO 3: PROPOSTAS PARA MELHORAR A SEGURANÇA PÚBLICA}

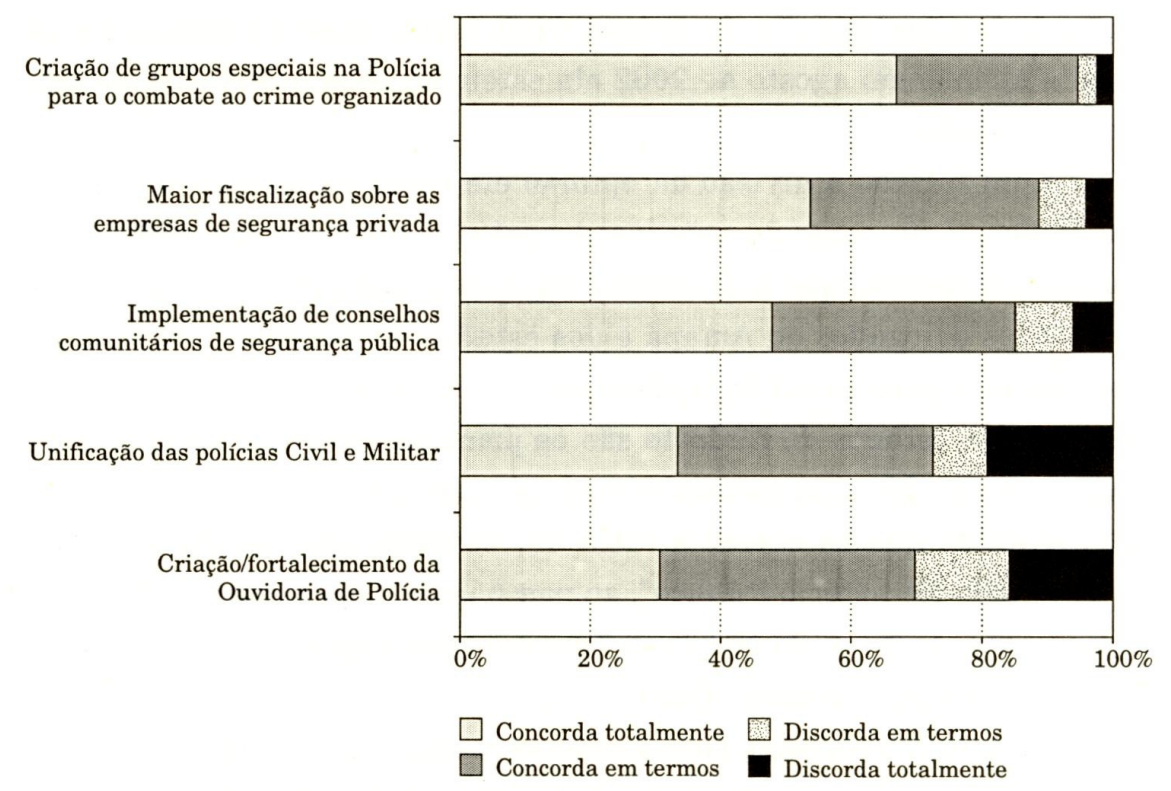

TEXTO DA PERGUNTA $\mathrm{N}^{\circ}$ 25: “O Sr.(a) concorda com as seguintes propostas para melhorar a Segurança Pública?”

Obs.: Excluídos os que não responderam e os que assinalaram não ter opinião. Nessa pergunta, em média, 3,5\% dos entrevistados não responderam ou assinalaram não ter opinião sobre os itens mencionados.

Dois itens dessa pergunta dividiram um pouco a opinião dos entrevistados. No que diz respeito à "unificação das polícias Civil e Militar" - sem dúvida, um dos temas mais importantes da agenda de reformas do sistema de segurança pública - 73\% dos entrevistados concordaram "em termos" ou "totalmente" com a proposta e $27 \%$ discordaram "em termos" ou "totalmente". A questão da unificação das polícias tem sido debatida no Congresso Nacional e qualquer mudança nesse sentido terá que ser realizada por meio de emenda constitucional. Por outro lado, apesar de serem definidas nacionalmente, as polícias organizam-se e são comandadas pelos governos estaduais, guardando entre si (estados) diferenças importantes. A responsabilidade estadual sobre as polícias e o relativo grau de autonomia que têm os aparatos policiais de cada estado podem vir a influenciar o processo de decisão sobre a proposta de unificação das corporações civil e militar, exigindo a construção de um amplo consenso. Se essa hipótese estiver correta, é provável que a implementação dessa proposta enfrente sérias dificuldades exatamente porque a pesquisa revela que há diferenças significativas entre os estados brasileiros, no que diz respeito à unificação. Teste estatístico sobre essa questão revelou que os estados do Nordeste e principalmente os do Centro-Oeste são responsáveis mais do que os outros pela fração de quase um terço de discordância em relação à proposta de unificação. Do outro lado, os estados do Sudeste concordam mais do que os outros com a ideia de unificação das polícias, que é apoiada no geral por mais de dois terços dos entrevistados.

Outra diferença estatística significativa em relação à proposta de unificação foi encontrada quando comparamos os delegados que atuam nas capitais e os que atuam no interior: dentre os entrevistados que concordam com a proposta, os do interior destacam-se mais do que os outros no apoio à ideia. Já os delegados que atuam na capital são mais responsáveis do que os outros pelo índice de discordância de quase um terço em relação à unificação das polícias.

Outro item que despertou alguma divergência de opinião entre os delegados foi a proposta de "criação e/ou fortalecimento das ouvidorias de polícia", em relação à qual dois terços dos respondentes manifestaram concordância e um terço deles discordou. Teste estatístico revelou que o índice de concordância é maior no Nordeste, Sul e Centro-Oeste, ao passo que os delegados do Sudeste destacam-se no que diz respeito ao grau de discordância.

Com relação a propostas que têm sido feitas para diminuir a impunidade e a criminalidade (Gráfico 4), há quase unanimidade entre os delegados sobre a conveniência da criação do "plantão judiciário de 24 horas" (98\% concordaram "totalmente" ou "em termos" com a ideia). Em seguida aparece a ideia de retomar um recurso de poder que a Constituição 
de 1988 retirou dos delegados: 90\% querem de volta a possibilidade de "fazer busca domiciliar sem mandado judicial"20.

GRÁFICO 4: PROPOSTAS PARA MELHORAR O DESEMPENHO DO SISTEMA PENAL E DIMINUIR A IMPUNIDADE E A CRIMINALIDADE

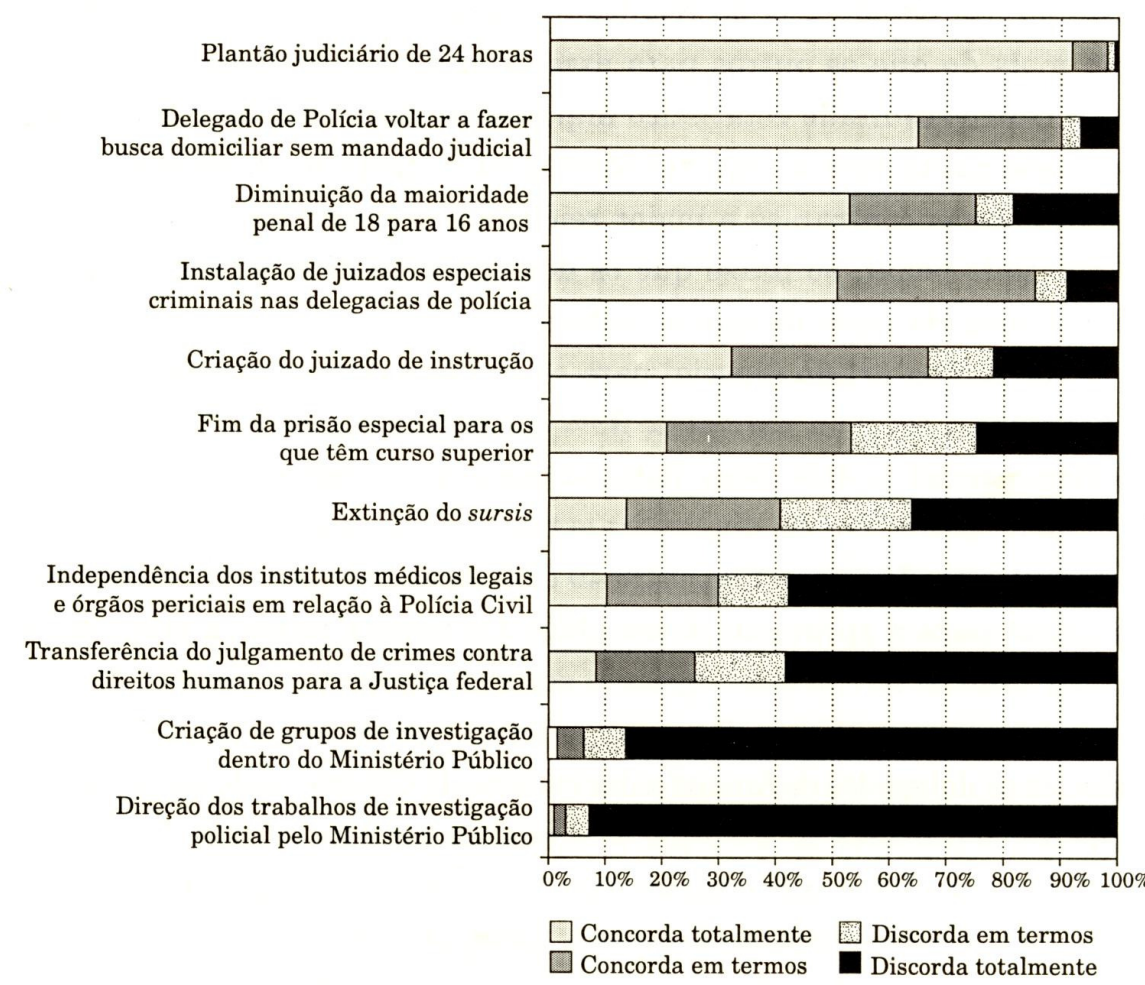

TEXTO DA PERGUNTA N’26: “Como o Sr.(a) avalia as seguintes propostas que têm sido feitas para melhorar o desempenho do sistema criminal e diminuir a impunidade $e$ a criminalidade?"

Obs.: Excluídos os que não responderam e os que assinalaram não ter opinião. Nessa pergunta, em média, 2,8\% dos entrevistados não responderam ou assinalaram não ter opinião sobre os itens mencionados.

${ }^{20}$ Essa ideia consta inclusive da "Carta de Rio Quente", documento com onze propostas elaborado por delegados de todo o país reunidos no "XI Congresso Nacional de Delegados de Polícia de Carreira”, realizado em Caldas Novas (GO), entre 16 e 19 de setembro de 2001.
Cerca de $85 \%$ também mostraram-se favoráveis à "instalação de juizados especiais criminais nas delegacias de polícia". As opiniões dividiramse em relação a algumas propostas que têm sido levadas a debate público. No que diz respeito à polêmica ideia de "diminuição da maioridade penal de 18 para 16 anos", três quartos dos entrevistados tendem a concordar com ela e, de acordo com teste estatístico, especialmente os delegados com mais de 50 anos de idade. Já os mais jovens, entre 20 e 40 anos, reforçam mais do que os outros o contingente de $25 \%$ daqueles que discordaram da proposta. No que diz respeito aos estados, os do Nordeste (Bahia e Pernambuco) contribuíram mais do que os outros para esse grau de discordância.

Outro resultado estatístico importante sobre esse item diz respeito à associação com a variável ideológica: é entre os delegados de esquerda que encontramos a maior rejeição à proposta de diminuição da maioridade penal, ao passo que os delegados de direita tendem a concordar com ela mais do que os outros.

O "fim da prisão especial para os que têm curso superior" obteve a concordância total ou parcial de 53\% dos entrevistados e a discordância total ou parcial de $46 \%$ deles. Estatisticamente, os delegados mais jovens, com idade entre 20 e 40, discordaram mais do que os demais em relação a essa proposta. Já os que têm entre 40 e 50 anos contribuíram mais do que os outros para a aprovação dessa ideia. Da mesma forma, a proposta de "extinção do sursis" foi mais rejeitada pelos mais jovens - entre 20 e 40 anos - ao passo que recebeu maior apoio entre os que estão na faixa dos 4050 anos. Já os delegados do Amapá e dos estados do Centro-Oeste concordaram mais com a proposta de "extinção do sursis" do que seus colegas dos estados do Sul e do Sudeste, que contribuíram para elevar o grau de discordância em relação a essa proposta. No geral, a "extinção do sursis" recebeu apoio de $40 \%$ dos entrevistados e foi rejeitada total ou parcialmente por $58 \%$.

A "independência dos institutos médicos legais e órgãos periciais em relação à Polícia Civil", proposta defendida pelo Fórum Nacional de Ouvidores de Polícia, foi apresentada em dezembro de 1999 e recebeu parecer favorável na Comissão de Constituição, Justiça e Cidadania em junho de 2000 (PEC 89/99). Pelo projeto, peritos e médicos legistas formariam carreiras independentes em órgãos especializados e autônomos em relação à 
Polícia Civil, com prerrogativas e funções definidas em lei específica. Caso fosse implementada, essa alteração certamente significaria perda de recursos importantes para a organização policial e não por acaso a Associação dos Delegados de Polícia do Brasil empenhou-se na derrubada do projeto.

Em setembro de 2001, o Voto em Separado do senador Romeu Tuma, contrário à mudança e atendendo reivindicação da Adepol-BR, foi aprovado pelo plenário da CCJ e a PEC 89/99 foi arquivada.

Apesar disso tudo, a proposta recebeu o apoio de quase 30\% dos entrevistados na pesquisa. Nesse contingente de delegados favoráveis à ideia, destacaram-se os mais jovens - menos de 30 anos - e aqueles que se declararam de esquerda. No que diz respeito às regiões, delegados do Amapá e dos estados do Nordeste foram os que mais contribuíram para a fração de quase um terço de concordância em relação a essa ideia.

Outra proposta que teria consequências importantes sobre a atividade das polícias estaduais é a "transferência do julgamento de crimes contra direitos humanos para a Justiça federal". Em discussão no Congresso Nacional desde 1996, quando o Poder Executivo apresentou proposta de emenda constitucional nesse sentido ${ }^{21}$, a federalização dos crimes contra os direitos humanos surgiu como resposta a episódios nos quais as polícias estaduais, especialmente a militar, estiveram envolvidas em violações a direitos humanos. Se aprovada pelo Congresso, essa proposta introduzirá uma forma indireta de controle sobre as polícias dos estados, uma vez que casos marcados por ações arbitrárias poderão ser transferidos para a Justiça federal, diminuindo as chances de impunidade que muitas vezes caracterizam a resolução desse tipo de processo judicial no plano estadual ${ }^{22}$.

Entre os delegados, essa ideia ganhou apoio de $24 \%$ dos entrevistados e $68 \%$ discordaram dela "totalmente" ou "em termos". Entre

\footnotetext{
${ }_{21}^{21}$ PEC 368/96, posteriormente apensada à PEC 96/92 relativa à reforma do Poder Judiciário. ${ }^{22}$ Diz o projeto de reforma do Judiciário aprovado pela Câmara dos Deputados e em tramitação no Senado: "Nas hipóteses de grave violação de direitos humanos, o ProcuradorGeral da República, com a finalidade de assegurar o cumprimento de obrigações decorrentes de tratados internacionais de direitos humanos dos quais o Brasil seja parte, poderá suscitar, perante o Superior Tribunal de Justiça, em qualquer fase do inquérito ou processo, incidente de deslocamento de competência para a Justiça federal".
}

os estados, Amapá e os estados do Nordeste foram os principais responsáveis pelo grau de aprovação verificado, ao passo que os delegados dos estados do Sudeste destacaram-se pelo grau de discordância.

No que diz respeito à "criação dos juizados de instrução", os delegados mais velhos - 50 anos ou mais - concordam mais do que os outros com a proposta. Inversamente, é entre os delegados com menos de 30 anos que encontramos mais resistência a essa ideia. No geral, 64\% apoiam a criação do juizado de instrução e $32 \%$ tendem a rejeitá-la. Nos estados do Centro-Oeste, os delegados destacam-se por discordar da proposta do juizado de instrução, ao passo que os delegados do Amapá e dos estados do Sudeste destacam-se pelo apoio à ideia.

$\mathrm{Na}$ mesma linha de respostas anteriores, que apontaram profundas desconfianças em relação ao Ministério Público, 92\% dos entrevistados discordaram total ou parcialmente da ideia de "criação de grupos de investigação dentro do Ministério Público" e $96 \%$ dos delegados discordaram total ou parcialmente da proposta de "direção dos trabalhos de investigação policial pelo Ministério Público". A tendência inicial da comissão de reforma do Código de Processo Penal era retirar da autoridade policial a decisão de instaurar o inquérito policial. Por essa proposta os delegados realizariam apenas uma autuação sumária, cabendo ao Ministério Público a prerrogativa de instaurar ou não o inquérito policial. De acordo com a Adepol-BR, essa proposta teria como finalidade a extinção do inquérito policial e mais adiante a extinção da carreira do delegado de polícia $^{23}$. A proposta inicial foi abandonada e não constou do PL 4.209 enviado ao Congresso Nacional, que manteve os delegados de polícia como responsáveis pela investigação e pela instauração do inquérito policial.

\section{CONSIDERAÇÕES FINAIS}

Após a análise detalhada das opiniões dos delegados de polícia acerca da agenda de reformas da Polícia Civil e do sistema de Segurança Pública, temos pelo menos duas conclusões gerais.

${ }^{23}$ Anais do X Congresso Nacional de Delegados de Polícia de Carreira, Espírito Santo, outubro de 2000. 
A primeira delas é que se tornou evidente que os delegados de polícia vivem hoje um dilema de ordem institucional, no quadro mais amplo das instituições que compõem os sistemas de Justiça e de Segurança Pública.

De um lado, os delegados de polícia comparam-se às demais carreiras jurídicas (Magistratura e Ministério Público) e procuram conquistar as mesmas garantias e prerrogativas de exercício do cargo que juízes e promotores têm. Nesse sentido, eles perseguem maior insulamento institucional da polícia, o que pôde ser verificado pelo forte apoio manifestado às medidas pontuais de reforma que têm essa direção, abordadas pela pesquisa.

Por outro lado, é difícil imaginar que essa estratégia de equiparação institucional com os órgãos de justiça tenha êxito, uma vez que o aparato de força do Estado deve estar, em qualquer regime democrático, submetido ao controle político do poder eleito (normalmente o Executivo) e sujeito à fiscalização pelos órgãos judiciais. Nessa perspectiva, mesmo que os delegados de polícia venham a conquistar novas garantias e privilégios nesse processo de reforma, a completa independência institucional é uma hipótese que foge aos modelos convencionais de organização policial em regimes democráticos e, portanto, de improvável realização, por mais que o Brasil tenha uma história pródiga de cissiparidade e fortalecimento de nichos institucionais para os diversos órgãos que lidam com o Direito e com a aplicação das leis.

Entretanto, como vimos, é grande a insatisfação dos delegados de polícia com a submissão da polícia ao poder político. Os governos são criticados pelos delegados tanto por falta quanto por excesso: os governantes faltam ao deixarem de implementar políticas de Segurança Pública mais amplas e consistentes e se excedem quando interferem politicamente na cúpula da organização policial ou quando nomeiam leigos para o cargo de Secretário de Segurança Pública.

Pelo que vimos, ao lado do Poder Executivo, veio juntar-se um novo desafeto, com o qual a polícia também tem travado conflitos de independência: o Ministério Público. Seja pela via do controle externo passível de exercício pelo MP, seja pela substituição de delegados por promotores na condução da investigação criminal (ameaçando o monopólio garantido pelo inquérito em sua forma tradicional), o Ministério Público transformou-se em fonte principal de críticas dos delegados de polícia, como mostraram diversos resultados aqui analisados.
Em suma, pelo que se viu, a reforma da polícia terá de enfrentar esse dilema de identidade institucional, que tem marcado as relações entre a polícia, de um lado, e o Poder Executivo e o Ministério Público, de outro, e a solução desse impasse dependerá da capacidade de equilibrar garantias de atuação e controle público sobre a instituição ${ }^{24}$.

A segunda conclusão geral diz respeito às propostas de reforma consensuais e não consensuais entre os delegados de polícia entrevistados.

Como vimos, mostraram-se positivamente consensuais as propostas que implicam maior insulamento institucional da polícia e negativamente também consensuais as propostas que implicam perda do monopólio da investigação criminal e maior fiscalização externa sobre a instituição, especialmente se realizada pelo Ministério Público. Quanto ao controle interno, fortalecido pela ideia de uma carreira independente para a corregedoria, o grau de consenso diminui e a divisão de opiniões instala-se entre os delegados, tendo sido verificado maior apoio entre os delegados do interior e menor entre os da capital.

No que diz respeito à proposta de unificação das polícias Civil e Militar (questão central do debate sobre a reforma da polícia no Brasil), verificamos que há apoio à ideia, mas sua implementação dependerá da sorte de garantias e prerrogativas que o novo modelo atribuir aos agentes do sistema atual e, especialmente, o tipo de transição que se fizer de um modelo a outro. Seja como for, é importante destacar que, sendo a polícia uma organização estadual, a resistência mais forte à unificação foi encontrada nos estados do Centro-Oeste e Nordeste, enquanto o apoio mais consistente vem dos estados do Sudeste.

Por fim, mas não menos importante, os resultados demonstraram que, no que diz respeito à questão da impunidade e às mudanças no sistema e legislação penais, os delegados dividiram opiniões segundo uma combinação de idade e posicionamento ideológico: de um lado, os mais jovens e os de esquerda adotam uma posição digamos mais liberal diante de propostas que levariam a maior endurecimento da legislação penal (na

\footnotetext{
${ }^{24}$ Os textos de Maria da Glória Bonelli e Rosângela Batista Cavalcanti, que compõem este livro, também analisam aspectos importantes desse dilema institucional e fornecem hipóteses interessantes sobre suas origens e desdobramentos.
} 
questão da maioridade penal, da prisão especial e do sursis, por exemplo), enquanto os delegados mais velhos e os de direita adotam uma posição mais restritiva em relação a esses temas. Tal divisão, entretanto, ocorreu apenas no que diz respeito a essa agenda "externa", o mesmo não se verificando quanto aos temas institucionais e organizacionais que, como vimos, unificam os delegados em torno do desejo de maior independência da função policial e menor interferência das instituições políticas e judiciais sobre a polícia.

\section{Referências Bibliográficas}

ASSOCIAÇÃO dos Delegados de Polícia do Brasil (2002). Disponível em: http://www.adepolbrasil.com.br.

ASSOCIAÇÃO dos Delegados de Polícia do Estado de São Paulo (2002). Informativo da ADPESP. São Paulo, mar.

CUNHA, Luciana Gross Siqueira (2000). "Ouvidoria de Polícia em São Paulo". In SADEK, Maria Tereza (org.). Justiça e Cidadania no Brasil. São Paulo, Idesp/ Sumaré.

FOLHA DE S. PAULO (2001). 17 jan., p. A-4.

(2001). 18 dez., p. C-4.

MARIANO, Benedito Domingos; BICUDO, Hélio \& TELLES JÚNIOR, Goffredo (2000). "A Polícia que Temos e a que Queremos". Folha de S. Paulo, 23 de fevereiro, pp.1-3.

MÉNDEZ, Juan E.; O’DONNEL, Guillermo \& PINHEIRO, Paulo S. (2000). Democracia, Violência e Injustiça: O Não Estado de Direito na América Latina. São Paulo, Paz e Terra.

O ESTADO DE S. PAULO (2002). "Governo Vai Mudar Plano de Segurança de Novo", 29 jan.

(2002). "Comissão Começa a Preparar Pacote Contra a Violência", 19 fev.

PANNUNZIO, Antonio Carlos (2002). "Relatório e Substitutivo Apresentados à CREDEN", maio.

\section{Problemas e Desafios da Polícia Civil}

\section{As PerCePÇões dos Delegados}

Rosângela Batista Cavalcanti

\section{INTRODUÇÃO}

Concluindo, gostaríamos de agradecer a sua colaboração. Solicitamos que utilize o verso desta página se tiver comentários a fazer sobre a nossa pesquisa ou se quiser esclarecer ou complementar alguma resposta. Obrigado

A solicitação acima foi feita com o objetivo de o entrevistado acrescentar alguma questão não contemplada pelo questionário ou complementar alguma resposta. Mais do que isso, tornou-se um "fórum de desabafo" para os delegados e delegadas de polícia que se dispuseram a tecer comentários sobre assuntos variados. Do ponto de vista analítico, revelou-se um instrumento importante para captar sentimentos e opiniões mais detalhadas acerca de assuntos conjunturais ou estruturais que atingem o universo investigado.

Trinta e sete por cento $(37 \%)$ dos entrevistados fizeram comentários ${ }^{1}$ Esse percentual relevante ${ }^{2}$ indica que os entrevistados valorizaram o espaço para expor e explicitar suas avaliações sobre os temas abordados - talvez devido à abrangência do questionário, ancorado em cuidadosas entrevistas em profundidade com delegados selecionados e em vários levantamentos de informações em fontes secundárias, poucos assuntos que não constavam dele foram mencionados. Ao contrário, os delegados se manifestaram mais justamente sobre aqueles temas que constam do questionário e cujos

${ }^{1} \mathrm{O}$ estado do Paraná destaca-se com o alto percentual de $56 \%$ de comentários, seguido do Rio Grande do Sul, com $42,6 \%$. No outro extremo, estão os estados de Goiás (22\%), Distrito Federal $(29,2 \%)$ e Bahia $(29,5 \%)$. Nos demais estados, os resultados são os seguintes: São Paulo (38\%), Amapá (35,3\%), Rio de Janeiro (33\%) e Pernambuco (31,3\%).

${ }^{2}$ Evidentemente, embora trate-se de número expressivo, as opiniões destacadas não podem servir como parâmetro de avaliação dos sentimentos de toda a categoria. 
percentuais de respostas "muito importante" e "importante" somados geralmente ultrapassam os $80 \%$. Por exemplo, a "falta de empenho governamental" foi apontada como um sério obstáculo para o bom funcionamento da Polícia Civil por 94,7\% (soma das respostas "muito importante" e "importante") dos respondentes do questionário; e nos comentários, o "descaso do governo" com a Polícia Civil foi amplamente debatido. Ainda com relação à interface da Polícia Civil com o Poder Executivo, temos que $89,6 \%$ dos entrevistados indicaram a "interferência política na cúpula da instituição" como outro sério obstáculo ao seu bom funcionamento, enquanto grande número de delegados que elaboraram comentários mencionou esse problema. A promulgação da Lei Orgânica Nacional da Polícia Civil é vista por $82,6 \%$ dos entrevistados como muito importante para melhorar o funcionamento da Polícia; nos comentários, verifica-se que essa proposta é a que mais recebe adesão dos delegados. $\mathrm{Na}$ mesma direção, a conquista da inamovibilidade pelos delegados, considerada muito importante ou importante por $93 \%$ dos entrevistados, é outra proposta bastante mencionada.

O universo dos entrevistados que teceram comentários é composto por indivíduos que têm percepções razoavelmente homogêneas sobre fatores ou problemas que direta ou indiretamente atingem a Polícia Civil, mas a maneira como os delegados constroem as suas críticas ou os seus argumentos são diferentes. Ademais, a ênfase dada a determinado assunto, bem como a frequência com que é citado variam de estado para estado contemplado na amostra. Apesar dessas distinções, é possível encaixar as diversas opiniões nos seguintes itens:

a) Polícia Civil e Poder Executivo: ingerência e descaso;

b) Garantias institucionais como saída para a crise: inamovibilidade e Lei Orgânica;

c) A Polícia Civil, o Ministério Público e a investigação criminal;

d) Polícia Civil e Polícia Militar: uma competição institucional e. A legislação;

e) Polícia Civil e meios de comunicação.
Nos comentários que fizeram, como veremos a seguir, os delegados de polícia descortinam sentimentos e opiniões sobre a instituição a que pertencem - expondo as suas fragilidades internas - e acerca dos múltiplos fatores responsáveis pela escalada da violência e da criminalidade no país. Esses atores, que desempenham um papel executivo e direto na gestão da segurança pública, também utilizaram o espaço disponível para expor ressentimentos - "o preconceito é muito grande [...] a corporação é tratada como um lugar onde só tem bandido e corrupto" - e explicitar a "função social" do delegado - "nenhuma outra autoridade pública conhece mais de perto os medos e necessidades básicas da população que o delegado de polícia, nos horários mais improváveis, é ele quem atende o pobre, o rico, o louco, a vítima, o desvalido etc.”. Através dos depoimentos, percebe-se que a Polícia Civil, muitas vezes acusada por seus "gestos truculentos", é também aquela que possui iniciativas visando a "humanização" de seus quadros e a aproximação com a população.

\section{PolíCIA CIVIL E PODER EXECUTIVO: INGERÊNCIA E DESCASO}

Os delegados admitem a existência de uma crise em sua instituição, mas na maioria das vezes atribuem-na a fatores externos, como ingerência ou descaso do Poder Executivo. A situação de "abandono material" a que o Executivo supostamente teria relegado a Polícia Judiciária é tão prejudicial ao seu bom desempenho quanto a ingerência maléfica que esse Poder exerce sobre a instituição, de acordo com os comentários:

[...] importa aqui mencionar a ingerência política (maléfica) às funções policiais. Como delegada de polícia assisto, diariamente, colegas se sentirem "amarrados" para tomar decisões sobre investigações e outros procedimentos quando estes vão de encontro aos interesses dos políticos (deputados e vereadores). [...] os políticos são tão ousados que chegam a dizer abertamente que, se o delegado não atender a tal pedido, será removido. "A política é quem manda", dizem eles (Pernambuco).

Não interessa às autoridades competentes melhorar a polícia. Um ponto comum é a troca de delegados de polícia quando estes não são "puxa-sacos", ou apadrinhados de deputados, políticos em geral. No Paraná, tem que ter padrinho deputado estadual, pois cada parte do Paraná foi loteada entre os deputados com a conivência dos senhores 
governadores; e só com o aval desses deputados é que os delegados poderão trabalhar em tal cidade e aí o "pedágio" é grande (Paraná).

A Polícia Civil, para o bom desempenho de suas atividades, tem de ter autonomia funcional e administrativa, com prerrogativas e garantias constitucionais que lhe permitam uma remuneração adequada e independência funcional, a fim de que não seja alvo de ingerências políticas que vão desde a falta de equipamentos até a exoneração, demissão ou destituição de cargos importantes ocupados por delegados de carreira (Distrito Federal).

O contínuo desmantelamento da Polícia Civil por causa da omissão ou intervenção indevida dos governos também é repetidamente mencionado no Rio Grande do Sul, mas nesse estado os julgamentos recaem diretamente sobre os sucessivos governos de esquerda:

Como integrante da carreira, ando preocupado com o desprestígio imposto pelos governos de esquerda. [...] A Polícia Civil está sendo alvo de tentativas de desestruturação total. Essa prática é equivocada e trará à população transtornos irreversíveis aqui no Rio Grande do Sul (Rio Grande do Sul).

No estado do Rio Grande do Sul, estamos passando por um desmonte da Polícia Civil - política essa empregada por uma ideologia esquerdista exacerbada (Rio Grande do Sul).

Portanto, não importando se se trata de governos de orientação político-ideológico mais à direita ou mais à esquerda, os delegados estão bastante descontentes com o tratamento dispensado pelo Executivo, que é apontado como responsável direto por muitas das mazelas da Polícia Civil, seja porque interfere demasiadamente na instituição, seja porque não fornece condições materiais adequadas para garantir uma atuação eficiente:

A Polícia Civil, para ser eficiente, precisa de recursos. Governo que desejar atender um dos anseios da população, que é a segurança pública, investe em polícia, fortalece sua polícia, o resto é clientelismo (Rio Grande do Sul).

O Estado tem o dever de preparar o policial para prestar serviços relevantes no combate ao crime organizado. É importante pagar salários dignos para que o policial não se envolva em crimes (Pernambuco).
Gostaria que os governantes dessem melhores condições de trabalho aos policiais, principalmente à Polícia Civil, que tem condições de trabalho bastante precárias, como também o salário, para que o policial tenha condições de prestar com mais eficiência o atendimento à população (Bahia).

O que a polícia está precisando mesmo, em todo território nacional, é de mais recursos (humano e material), para um bom desempenho funcional (Amapá).

A polícia poderia prestar um melhor serviço caso houvesse mais apoio por parte do Estado, pagando melhor seu pessoal e dando melhor condição de trabalho (Goiás).

A falta de infraestrutura, decorrente do descaso governamental, aliada às constantes interferências políticas, prejudica a autoestima do policial e consequentemente a aparição de crimes (Rio de Janeiro).

O policial civil está desestimulado com o salário que ganha e com a política administrativa do governo. Esse desestímulo traz negatividade e depressão; pessoas depressivas não têm condições psicológicas de dar atendimento adequado a qualquer cidadão (São Paulo).

Com poucas exceções, os delegados de polícia no Brasil são mal remunerados. Esse fato, embora não justifique, é um fator a mais que pode levar o servidor a se corromper. [...] Os baixos salários levam grande parte dos policiais, civis e militares, a exercerem outras atividades ou a fazerem "bicos" para a complementação da renda familiar (Distrito Federal).

Os policiais precisam ser tratados com mais dignidade pelos governantes (Paraná).

Mas os problemas relativos, simultaneamente, ao "descaso" e à "interferência política" na instituição não se restringem ao Poder Executivo, mas também ao Legislativo ou, de forma bastante vaga, à política, percebida como causa principal dos problemas que afetam não somente a Polícia Civil, mas o país:

Todos os problemas que temos (segurança, educação, saúde etc.) derivam apenas de um: o político. Decididamente, o problema brasileiro não é econômico (São Paulo). 
Pergunta-se: como um órgão que é encarregado de fazer cumprir a lei pode ser atrelado e subordinado ao poder político? Só pode não funcionar. Ou melhor, funciona, mas para os interesses do "príncipe" e não da sociedade (Rio de Janeiro).

Nesse tipo de crítica - que transcende o óbvio descontentamento com o tratamento dispensado à Polícia Civil pelo Executivo, ao qual é atrelada institucionalmente -, os delegados valem-se, de certa forma, da insatisfação generalizada da população com seus representantes eleitos - uma crise alimentada, certamente, por inumeráveis denúncias e escândalos de corrupção, mas não somente, pois está relacionada à fragmentação dos interesses sociais, à extensão da cidadania, ao fortalecimento da imprensa etc.-, justificando muitos de seus problemas por meio de fatores independentes de sua vontade ou da qualidade de sua atuação.

\section{GARANTIAS INSTITUCIONAIS COMO SAÍDA PARA A CRISE:} INAMOVIBILIDADE E LEI ORGÂNICA

A promulgação da Lei Orgânica Nacional da Polícia Civil, bem como a ampliação de garantias do delegado (inamovibilidade, por exemplo) são, de acordo com os comentários, caminhos eficazes para a solução dos principais problemas pelos quais passa a instituição:

A manipulação política, no interesse pessoal do vereador ao governador, promovendo a remoção compulsória dos policiais de um local a outro, em nada beneficia o trabalho da Polícia Civil, ao contrário, quer-se muitas vezes afastar para que não venha a causar problemas para eles. Inamovibilidade já (Paraná)

A inamovibilidade é uma das garantias mais importantes para o delegado; temos de conquistá-la em nível nacional (Goiás).

Sem garantias como a inamovibilidade, trabalha-se com o medo de desagradar, pois com um simples telefonema podemos ser transferidos para um local distante (Rio de Janeiro).

Necessitamos urgentemente de uma nova lei orgânica, forte e bem elaborada, para que possamos ser independentes (São Paulo).

\section{A Polícia Civil, o Ministério PÚBlico E a InVESTIGaÇÃo CRIMINAL}

Nos comentários cuja temática envolve conflitos de atuação entre a Polícia Civil e outros órgãos do sistema penal, o Ministério Público é disparadamente a instituição mais criticada pelos delegados. $\mathrm{O}$ principal motivo das críticas é a intervenção indevida de promotores na investigação e no inquérito policial:

Os promotores de justiça, usurpando da função, vêm desenvolvendo o trabalho de investigação policial (Rio Grande do Sul).

Mesmo que se tente apregoar que o MP deve tomar a frente da atividade policial, o fato é que não possuem preparo técnicoprofissional para isso (Rio Grande do Sul).

O MP não pode coordenar as investigações, pois é parte; tornaria o inquérito parcial e não mais imparcial como hoje é (Rio Grande do Sul).

[...] prega-se que o MP deve passar a presidir as investigações criminais, esquecendo-se que essa instituição faz parte do mesmo sistema penal. Com certeza, as injustiças seriam ainda maiores se o MP, que é o órgão da acusação e, portanto, parte no processo penal, presidisse as investigações criminais, cuja condução para um melhor esclarecimento da verdade, que possa levar a uma condenação ou absolvição justa, deve ser feita de maneira imparcial (Rio Grande do Sul).

No Brasil, está se criando uma cultura de que o MP pode substituir a polícia na investigação dos delitos e muito melhor, sendo que isso é uma falácia. Mesmo em países com Juizado de Instrução, como, por exemplo, nos Estados Unidos, o MP tem um papel secundário nas investigações, sendo a Polícia Judiciária quem investiga os fatos e o promotor apenas serve de elo de ligação entre esta e o Poder Judiciário (Rio Grande do Sul).

É uma piada agentes do Ministério Público conduzindo as investigações. Eles são burocratas estudiosos e nada mais. Não têm coragem moral e física para bater de frente com a delinquência, primando, tão só, pelo exibicionismo (Rio Grande do Sul).

Quanto ao Ministério Público e suas atribuições, num país com a extensão do Brasil e os recursos materiais desse órgão, ao invés de ajudar passarem a "investigar", só atrasaria os serviços (Paraná). 
Se o MP passar a dirigir a investigação policial, creio que deva ser então extinta a classe dos delegados de polícia, devendo a atividade ser exercida pelos membros do parquet. A investigação é uma atividade técnico-profissional, se os membros do MP se envolverem de modo desmedido, a seara jurídica do processo sem dúvida se ressentirá de maneira negativa (Paraná).

O Ministério Público deveria investigar, em última hipótese, os agentes públicos, porém, achando-se o dono da verdade, o intocável, quer ser polícia, logo mais, vai querer julgar. [...] O Ministério Público quer ser polícia, então, por não ter coragem, se alia à Polícia Militar e esta, por querer ser Polícia Judiciária, alia-se e sujeita-se ao MP, para prejudicar a Polícia Civil (Paraná).

Entendemos que o maior entrave à atuação da Polícia Civil tem sido a nefasta ação do Ministério Público em sua ânsia de assumir a presidência do inquérito, em conduzir as investigações, em usurpar, enfim, todas as funções da Polícia Civil e em especial dos delegados de polícia (Goiás).

A falsa impressão de que membros do Ministério Público trariam celeridade e confiabilidade à apuração criminal não deve prosperar. Tais profissionais são totalmente estranhos às atividades policiais, desconhecem técnicas de investigação e não possuem perfil apropriado. Se, por vezes, surgem como paladinos da justiça, "auxiliando" em investigações realizadas por delegados, nota-se que são casos em que a mídia atua, não havendo interesse daquela instituição em acompanhar casos sem expressão, que são a maioria esmagadora. Por outro lado, no Direito brasileiro, o membro do MP é parte no processo, o que de pronto afasta sua atuação durante a persecutio (São Paulo).

O MP deveria voltar a ser somente parte na relação processual, perdendo o poder de fiscalização. Como um fiscal pode ser parte processual? (Rio de Janeiro).

Entendo ser necessário o MP exercer com afinco suas funções e deixar de querer ser polícia (Rio de Janeiro).

A Polícia Civil é um órgão que busca a verdade real. Exerce atividade investigatória de forma imparcial. Já o Ministério Público é um órgão de acusação absolutamente parcial. Desta forma, as provas obtidas em um inquérito presidido pelo MP seriam a verdade da acusação e nunca a verdade real e justa que todos esperam, sendo nulas de pleno direito (Rio de Janeiro)

[Deveria haver] maior dedicação do Ministério Público na questão policial, mas não tentar substituir a polícia, como eles querem (Amapá).

O MP passou a querer controlar todo o trâmite e serviços de delegacia, em alguns casos, querendo até mandar no delegado (Paraná)

Quanto ao "controle externo" da polícia civil pelo Ministério Público não deveria ser da forma como foi imposto. Quem vasculhará as gavetas do Ministério Público? Ou lá somente tem homens de bem, que não erram? Da forma avassaladora com que atacam a todos, dever-se-á, também, ter uma fiscalização das ações desse órgão (Rio Grande do Sul).

Mas as críticas ao Ministério Público não recaem exclusivamente sobre a questão da suposta "invasão" da arena investigativa, mas revelam também que delegados de polícia ressentem-se do fato de que promotores e procuradores de justiça possuem muito mais garantias institucionais e mais poder que delegados de polícia.

$\mathrm{Na}$ comparação com outras carreiras jurídicas, incluindo-se os integrantes do Poder Judiciário, os delegados demonstram profundo descontentamento com o tratamento desigual - seja com relação a salários ou prestígio social:

O sistema de aplicação de justiça, sobretudo a penal, não pode dispensar ao delegado de polícia outro tratamento senão aquele semelhante a juízes e promotores, notadamente no que se refere a salário, prestígio e posição social (Bahia).

O delegado de polícia é uma função jurídica - como a de juiz, de promotor de justiça, de defensor público - e deve ser tratada como tal, sobretudo por seus direitos, deveres e atribuições. A remuneração do delegado de polícia, que não poderia ser diferente de outras carreiras jurídicas, deveria recompensar positivamente a atividade policial (Pernambuco).

Entendo que o delegado de polícia merece ter o mesmo tratamento jurídico, institucional e remuneratório dispensado aos juízes e 
promotores, afinal de contas, para ser delegado é necessário ter o curso de Direito (Goiás).

É bom que se destaque que o delegado de polícia é um dirigente policial e não um policial. Ele é, na verdade, um operador do Direito, como os demais, e assim deve ser tratado (São Paulo).

Para a polícia nada, para o MP e o Judiciário imunidades e privilégios (Rio de Janeiro)

No dia em que houver para a Polícia Civil as mesmas garantias do Ministério Público e do Judiciário, com certeza a atividade da Polícia Judiciária será exercida de forma muito mais satisfatória (Rio de Janeiro).

$\mathrm{Na}$ visão dos delegados, enquanto o Ministério Público deve ser responsabilizado pela dificuldade de preservação da ordem pública e pela interferência indevida na Polícia Civil, o Judiciário deve ser culpabilizado pela inércia:

[o problema da segurança pública] é a ingerência formalista de membros do MP, que não se atêm à realidade social, econômica e cultural do país, adotando conduta típica de modismo importado de centros europeus, que nada têm com nossa vida prática, seja política ou cultural (Goiás).

É de se ressaltar que o Judiciário nunca favorece o serviço desenvolvido pela polícia, utilizando-se dos prazos para não atender de forma sumária a sociedade (Goiás)

Um dos grandes obstáculos ao trabalho da polícia tem sido a inércia quase total do Poder Judiciário. A inoperância desse Poder, a ponto de sequer responder negativamente às representações por temporárias, preventivas, buscas domiciliares etc., tem impedido a Polícia Judiciária de colher os frutos das investigações (Bahia).

A segurança pública está diretamente ligada à atuação das duas polícias (Civil/Militar) e o Judiciário está ligado à "insegurança pública", pois em quatro anos na mesma unidade policial, eu particularmente já autuei em flagrante o "mesmo indivíduo" três vezes por prática de crime contra o patrimônio. Não adianta a Polícia Militar reprimir, a Polícia Civil agir se a impunidade persistir (São Paulo).
[Deveria haver] interesse maior do Judiciário pela questão da violência, pois são omissos, fazendo apenas beneficiar e incentivar a criminalidade (Rio de Janeiro)

\section{POlícIA CiVIL E POLÍCIA MILITAR: UMA COMPETIÇÃO INSTITUCIONAL}

Para os especialistas na área de segurança pública, a diferenciação da polícia em dois ramos distintos - Polícia Civil e Polícia Militar - esgotou-se como modelo de controle da criminalidade, pela ineficácia de seus resultados, pelos altos custos de sua manutenção e pela enorme complexidade de seu gerenciamento. À primeira vista, os delegados também tendem a concordar com essas afirmações:

A unificação das polícias civil e militar, bem como os institutos de perícia em um só órgão, reduziria os custos do Estado, aumentaria eficiência, diminuiria os entraves burocráticos e afastaria os conflitos de competência (Rio Grande do Sul).

A unificação das polícias estaduais deve ser priorizada, uma vez que essa bipolaridade tornou-se insuportável (Pernambuco).

A unificação proporcionará maior conforto ao cidadão, que desconhece as diferenças de atuação de ambas [as polícias] e somente quer ver os problemas resolvidos (Paraná).

[É necessária] a unificação da Polícia Civil e da PM, buscando-se soluções em conjunto com a população e poderes constituídos, tendentes a minimizar os problemas da segurança pública (Bahia).

Não existe perspectiva de melhoria em médio prazo, na segurança pública, sem que haja unificação das duas polícias. Duas polícias, uma invadindo a área da outra (nas coisas que dão ibope), e ninguém faz a sua parte a contento, dentro de suas competências constitucionais. Falta pessoal nas duas, criam-se delegacias especializadas, não as suprem de pessoal, desfalcam outras, tudo de improviso (São Paulo).

A unificação das polícias deveria ser estudada no Legislativo po pessoas com experiência na área de segurança pública; levando-se em conta a realidade de cada estado e sem conotação políticoeleitoreira, como é tratada hoje (Distrito Federal) 
Mas as suas apreciações com relação a esse ponto extrapolam a preocupação com a condução de políticas de segurança mais amplas e guardam uma estreita relação com uma antiga competição travada entre os dois ramos da polícia estadual. Alguns delegados, por exemplo, acusam a Polícia Militar de fazer lobbies para manter supostos privilégios e de ser muito distanciada da população:

Embora a Polícia Militar tenha um lobby muito forte para manter seus privilégios e seja contrária à unificação das polícias, essa é a única saída para termos uma polícia forte, mais eficiente e menos corrupta, voltada para a sociedade (São Paulo).

A formação militar básica (ordem unida etc.) desincompatibiliza o policial com a população, pois não o faz integrado a ela, formando-o como um ser à parte. Isso é uma filosofia de instituição e nunca mudará com paliativos. É flagrante a diferença de pensar e ver as coisas de um militar, especialmente os oficiais, e um civil. $\mathrm{O}$ militarismo faz ver inimigos na sociedade, quando na verdade o policial é um prestador de serviços ao indivíduo, que nem precisa estar com a cidadania em dia, e não a sua instituição ou ao Estado (São Paulo).

Em outros depoimentos, a Polícia Militar é apontada como uma instituição ineficiente e menos cobrada que a Polícia Civil pela crise da segurança pública:

A Polícia Militar vem se mostrando ineficiente na prevenção dos delitos, contudo, quando a segurança pública mostra-se preocupante, as atenções são voltadas para a Polícia Civil e cobram-se explicações e providências (Rio Grande do Sul).

O relacionamento ruim com a Polícia Militar é porque essa instituição está "escolhendo" suas atribuições, ou seja: está decidindo o que quer fazer e o que não quer. E a Polícia Civil fica somente com o lado ruim do trabalho policial, levando a culpa pela insegurança pública (Paraná).

Bastante indicativo dessas antigas divergências é o depoimento de um delegado que apontou a "extinção da Polícia Militar" como proposta para melhorar a segurança pública:

A pergunta de número 25 merecia a opção extinção das PMs. Não há sentido em manter a Polícia Militar (Rio de Janeiro).
Portanto, os comentários evidenciam a tensão histórica entre as duas polícias. E esse conflito também pode ser verificado nas respostas dadas ao questionário, em que 26,7\% dos entrevistados demonstraram resistência com relação à unificação das polícias Civil e Militar como proposta para melhorar a segurança pública.

\section{A LEGISLAÇ̃̃O}

No que diz respeito à legislação atual, os delegados apontam a exclusividade do juiz para o mandado de busca e apreensão como a principal causa do aumento da criminalidade:

A Constituição Federal, promulgada em 1988, enfraqueceu a autoridade do delegado de polícia, quando deu ao juiz autonomia no que diz respeito ao mandado de busca e apreensão. O delegado que preside o inquérito policial tem todas as informações possíveis para execução do serviço, apreensão de objetos e de pessoas até; quando solicitado ao juiz, simplesmente é negado, com justificativa sem nexo, porém, se o delegado for amigo ou bajular o juiz, ele decreta a preventiva ou o mandado de busca e apreensão (Amapá).

Para melhorar a segurança do povo: volta das expedições de mandado de busca e apreensão pelo delegado de polícia (Rio Grande do Sul).

[...] nos ressentimos pela falta de um sistema de normas realista. [...] é imprescindível a expedição de mandado prévio para a realização de busca domiciliar. Dispomos de magistrados e promotores seis horas por dia, de segunda a sexta. Em média levam-se quinze dias para sua expedição. Com realismo: os objetos permanecerão onde se encontram aguardando esse momento? Difícil é confundir a vontade do cidadão vítima com a realidade da lei (Pernambuco).

A Constituição Federal tem de ser reformulada a fim de ser dado ao delegado de polícia o poder de realizar busca e apreensão, quebra de sigilo telefônico e informações bancárias (Rio de Janeiro).

Importante seria o retorno da busca domiciliar, em certos casos, para que não desaparecessem as provas do crime. Hoje, até conseguir uma busca domiciliar na justiça, leva-se no mínimo cinco dias, tempo suficiente para consumir qualquer objeto (Paraná).

[...] Sentimos dificuldades e tristeza quando perdemos um trabalho em virtude da demora nas respostas das representações por busca e 
apreensão, que na maioria das vezes são indeferidas porque o juiz ou o MP entendem não haver justa causa ou insuficiência de elementos para deferimento da medida. De igual forma, já fiquei mais de seis horas na porta de um gabinete de um promotor de justiça aguardando um breve parecer (manifestação) relativo à Representação de Prisão Preventiva, que foi emitido após a saída do juiz, obrigando a me deslocar até a residência do juiz de plantão, passando-se mais de quatro ou cinco horas até obter o mandado. A meu ver são as piores dificuldades no exercício da profissão (Distrito Federal).

Inovações legislativas, como a Lei 9.099/95, também são apontadas como responsáveis pelo aumento da impunidade, devido à falta de rigor:

Com o advento de tal norma (Lei 9.099), buscava-se acelerar a prestação jurisdicional; o efeito, todavia, foi o contrário: quizilas que eram até então resolvidas eficazmente nas delegacias de polícia, tais como ameaças, vias de fato, lesões corporais leves (principalmente entre cônjuges), hoje são (pela facilidade da feitura do termo circunstanciado) levadas ao conhecimento do Poder Judiciário, aumentando de muito o número de feitos policiais. Faça-se, por exemplo, um exame comparativo do número de casos de "ameaça" de conhecimento do PJ de antes e depois da vigência de tal lei e constatar-se-á, com certeza, um multiplicador estratosférico (Rio Grande do Sul).

Entendo que a legislação penal deveria ser mais rigorosa, pois algumas leis que têm surgido, como a Lei 9.099/95, geram uma grande sensação de impunidade e, ao tratar de forma branda crimes praticados com violência e ameaça, estimula que outros ainda mais graves sejam praticados (São Paulo)

Mas os depoimentos coletados apontam tanto certezas como ambiguidades. Os mesmos agentes que apontam a legislação "branda" ou a sua "falta de rigor" como causas do aumento da criminalidade, são também aqueles que se mostram razoavelmente abertos ao envolvimento da polícia com a comunidade, como caminho para minimizar os problemas da segurança pública. Em tempos de priorização da prevenção em lugar da repressão, ou "do comunitário ou proativo em contraponto ao modelo ‘profissional clássico', reativo” (ver Bayley e Skolnick, 2001), os delegados tendem a valorizar, ou pelo menos não desprezam, propostas que viabilizem essa aproximação, como é o caso dos Conselhos de Segurança (Consegs) ${ }^{3}$ :

Gostaria de informar que procuramos nesta 8 secção contato bastante profundo com a população, com reuniões mensais com a comunidade, além do trato com os Consegs (São Paulo).

Acho que o atendimento ao público feito com respeito, independente de classe social, é fundamental para melhorar a imagem da Polícia Civil. A criação dos Consegs já foi um grande avanço (São Paulo)

O anseio da população brasileira por uma administração pública orientada por princípios éticos é crescente. Nos dias atuais, nenhuma instituição - ou nenhum Poder de Estado - pode se dar ao luxo de "fazer ouvidos moucos" às reivindicações por transparência em suas ações. As polícias e todo o aparato de justiça, considerados tradicionalmente avessos a intromissões externas, também têm sentido a força do controle social ou de outros órgãos públicos. E, não raro, têm sido chamados a explicar ou justificar determinados atos ou omissões. Programas sociais desenvolvidos pela polícia, como os Consegs - proposta cujo alcance ainda é desconhecido -, são indicativos de que a instituição está atenta a essa nova ordem, sob pena de perda de legitimidade e impopularidade.

\section{POLÍ́CIA CIVIL E MEIOS DE COMUNICAÇÃO}

Sondagens da opinião pública sobre questões ligadas à polícia mostram avaliações muito negativas sobre sua atuação. A primeira ideia associada à polícia é negativa: 52\%, segundo pesquisa do Instituto Datafolha (1999). Cerca de $20 \%$ da população de São Paulo foi vítima de assaltos entre os anos de 1991 e 1995, desses estimados dois milhões de pessoas vitimadas, 77\%

${ }^{3}$ Os Consegs "são grupos de pessoas do mesmo bairro ou município que se reúnem para discutir, planejar e acompanhar a solução de problemas comunitários de segurança, desenvolvendo campanhas educativas e buscando cooperação entre as várias lideranças locais; cada conselho é uma entidade de apoio à Polícia Estadual nas relações comunitárias e se vincula às diretrizes emanadas da Secretaria de Segurança Pública, por intermédio do Coordenador Estadual para Assuntos dos Conselhos Comunitários de Segurança" (Secretaria de Segurança Pública). As reuniões dos conselhos são mensais, realizadas normalmente no período noturno, em imóveis de uso comunitário. A Secretaria de Segurança Pública tem como representantes, em cada Conseg, o Comandante de Companhia da Polícia Militar da área e o Delegado de Polícia Titular do correspondente Distrito Policial. 
deixaram de notificar a polícia sobre o crime sofrido. Motivos: para 19\%, despreparo ou ineficiência da polícia, para $12 \%$, a violência dos policiais, para $10 \%$, a corrupção, para $7 \%$, ineficiência no combate ao crime, além de outras razões apontadas. Para os delegados que fizeram comentários, essa imagem negativa é reforçada pelos meios de comunicação que, segundo eles, é parcial ao expor os problemas e falhas da instituição:

[...] em todas as instituições existem bons e maus profissionais, por que, então, generalizar somente a instituição policial? As mazelas da polícia são mais expostas na mídia. Por que dizer que as corregedorias das polícias são corporativas? Será que a do MP ou da Magistratura não são? (Pernambuco).

[...] o interesse da mídia é que a polícia seja colocada sempre como responsável pela impunidade (Goiás).

A Imprensa também sabe macular nossa imagem, mas quase não divulga as boas ações ou mesmo a morte de nossos heróis em combate. Qual a divulgação dos casos dos policiais mortos no episódio do helicóptero? Apenas algumas linhas. Porém, se um bandido morre, a matéria é veiculada por vários dias (São Paulo).

A imprensa, na grande maioria das vezes, causa um efeito negativo quanto à repressão aos crimes. Nunca os noticiários divulgam um trabalho bem feito pela polícia (Rio de Janeiro).

Fator preponderante na formação da imagem negativa da Polícia Civil é a exploração sensacionalista feita pelos meios de comunicação. A divulgação de fatos negativos, a forma tendenciosa pela qual são expostos e a ocultação do trabalho da Polícia Civil, que não aparece, faz com que a imagem da polícia seja abalada e que o infrator se sinta impune diante dos órgãos de repressão do Estado (Distrito Federal).

De acordo com os delegados, os meios de comunicação também colaboram para difundir na população a ideia de que o órgão policial é contrário aos anseios democráticos; um resquício, segundo eles, de épocas anteriores, em que a polícia foi utilizada indevidamente para a manutenção do regime autoritário iniciado em 1964:

A Polícia Civil possui um estigma que demorará um certo tempo para a comunidade em geral esquecer. Tal estigma remonta a épocas de arbitrariedades que não mais coadunam com a conduta policial contemporânea (Rio Grande do Sul).
A polícia é uma instituição necessária em qualquer regime político, para, como um conjunto de serviços organizados pela Administração Pública, assegurar a ordem pública, a integridade física e moral das pessoas, mediante certas limitações impostas à atividade individual. A Polícia Política foi extinta. A Polícia de Segurança existente deve ser prestigiada, como as Forças Armadas, e não desprestigiada (Bahia).

Infelizmente a polícia de hoje sofre as consequências das práticas realizadas durante o regime militar. Não há discernimento por parte da sociedade das mudanças ocorridas nesses quase trinta anos. As críticas que sofremos teriam de ser estendidas também ao Ministério Público e ao Poder Judiciário, que também foram coniventes com os desmandos da época (São Paulo).

A Polícia Civil como instituição democrática serve à ideologia contida na nossa Constituição Federal. Infelizmente, já fomos utilizados em regimes autoritários, o que levou ao distanciamento da sociedade a que servimos (Distrito Federal).

\section{CONCLUSÃO}

A criminalidade violenta está atingindo índices alarmantes nas cidades brasileiras. Com um índice de 25 assassinados por 100 mil habitantes/ano, como coeficiente nacional, o Brasil encontra-se em posição extremamente desfavorável perante outros países, não só entre aqueles que costumam apresentar baixos índices de violência, como Japão (coeficiente de 0,6), Inglaterra e França (1,0), mas também na América Latina, onde só perde para a Colômbia. Argentina, Paraguai, Chile, Costa Rica detêm índices próximos de 5. Os dados do Datasus, do Ministério da Saúde (1997), revelam dados inquietantes na maioria dos estados quanto ao coeficiente de homicídios, principalmente porque os índices estão ponderados com populações de cidades interioranas menos afetadas pela violência. As regiões metropolitanas mostram que nos grandes aglomerados urbanos estão os índices mais altos de violência. Os índices coletados na Grande São Paulo, no primeiro semestre de 1999, quando comparados com períodos anteriores, por meio de médias mensais, mostram uma evolução acelerada dos principais delitos: aumento de 60\% entre 1997 e 1999 e aumento de $131 \%$ entre 1994 e 1999. 
A cidade de Goiânia, que também dispõe de um bom contingente policial (um policial para cada duzentos habitantes), apesar de uma redução de homicídios em 5\%, entre 1997 e 1998, teve um aumento expressivo nos roubos nesse período: $41 \%$ (Datasus, 1997).

A violência não é mais fenômeno restrito aos grandes centros e às cidades periféricas das capitais. No estado de São Paulo, por exemplo, a comparação por coeficientes de delitos por dez mil habitantes coloca a Capital em $20^{\circ}$ lugar na incidência de homicídios, dentre as cidades do estado (1998). Com um coeficiente de 5,22, a cidade de São Paulo está longe de Diadema (330 mil habitantes e coeficiente de 10,76), São Sebastião (41 mil habitantes; 10,15), São Vicente (283 mil; 6,63) ou Montemor (33 mil; 5,44). No coeficiente de roubos, a cidade de São Paulo, com 96,4 roubos para dez mil habitantes/ano, ocupa a quarta posição entre as cidades do estado (Instituto Fernando Braudel de Economia).

Nesse cenário, as instituições do sistema de justiça tornam-se alvo de críticas constantes, apontadas como as principais responsáveis pela situação da segurança pública. No caso das polícias, que possuem um papel executivo e direto na gestão da segurança pública, a desconfiança é ainda maior. Como mencionado, os delegados justificam-se afirmando que há muitos fatores, sobre os quais não têm controle, que dificultam uma boa atuação da instituição, como a legislação atual, e apontam a inércia de outros atores envolvidos na questão da segurança pública como causa da crise.

Ademais, dos comentários feitos por delegados de polícia de nove estados brasileiros, é possível concluir que é preciso prestigiar a polícia, pagando-a melhor e conferindo-lhe maior autonomia. É necessário, também, mudar o Código de Processo Penal, diminuindo as possibilidades de recursos e de prescrição da pena. De acordo com os delegados, é importante, ainda, uma mudança radical de atitude dos brasileiros em relação à polícia, não acostumados a pensar nela como instrumento de garantia de direitos e preservação da ordem pública, mas tão somente como um "órgão de contenção do descontentamento social". Este último aspecto, que remete à relação frequentemente tensa entre polícia e sociedade democrática, ao que parece, está longe de se esgotar, mesmo com a implementação de um novo modelo de polícia ou com a superação de suas principais deficiências.

\section{Referências Bibliográficas}

BAYLEY, David H. \& SKOLNICK, Jerome H. (2001). Nova Polícia: Inovações nas Polícias de Seis Cidades Norte-Americanas. São Paulo, Edusp (tradução de Geraldo Gerson de Souza).

DATASUS (1997). Ministério da Saúde.

INSTITUTO Datafolha (1999). "Pesquisa de Opinião Pública”. São Paulo.

INSTITUTO Fernado Braudel de Economia (1998). 


\section{Delegada: Doutora e Policial}

Maria Tereza Sadek

São conhecidas as dificuldades da participação da mulher na vida pública. Transpor as portas do lar e ingressar no mundo do trabalho e na política são conquistas recentes, mas distantes ainda de um patamar de igualdade, como impõem os preceitos da cidadania. Práticas discriminatórias, abertas ou sutis, afetam a universalização dos direitos civis, políticos e sociais.

Efetivamente, dados sobre o mercado de trabalho indicam que, embora venha crescendo o número de mulheres na força de trabalho, sua proporção em postos de chefia é mais reduzida do que a de homens e sua remuneração comparativamente mais baixa. Da mesma forma, a participação política feminina no eleitorado, apesar de hoje compatível com sua proporção na população, é muito desigual na elite política. Sublinhe-se, inclusive, que em atividades de representação, ações afirmativas ainda não alcançaram resultados capazes de atenuar de modo significativo a expressiva diferença de participação por gênero ${ }^{1}$.

O diferencial na participação de homens e mulheres no espaço público não é o mesmo em todas as áreas. Há, sem dúvida, esferas em que o ingresso feminino provocou menos resistências, quer porque entendida como mais compatível com as atribuições familiares, quer por não comprometer estereótipos sobre os papéis masculinos e femininos, ou ainda por serem pouco disputadas por homens. Por outro lado, a necessidade de arcar ou de cooperar para a renda doméstica explica a já antiga e forte presença de mulheres dos grupos sociais mais pobres em ocupações menos especializadas.

A escolaridade crescente das mulheres vem contribuindo para a ampliação de sua participação no mercado de trabalho, particularmente em ocupações que exigem maior formação educacional. Assim, o aumento do

${ }^{1}$ Apesar da lei de cotas, que estabelece um mínimo de $30 \%$ de mulheres no total das candidaturas, os partidos estão longe de preencher as vagas reservadas às mulheres, seja para a Câmara dos Deputados, para as Assembleias Legislativas ou para as Câmaras Municipais. número de mulheres em cursos universitários responde em boa medida pela presença feminina em carreiras de nível superior. Nos últimos anos, tem-se assistido a uma quebra da exclusividade masculina em diversas áreas, com a extensão da presença de mulheres em profissões anteriormente vistas como um privilégio ou uma "reserva de mercado" de homens. A mulher portadora de carteira de trabalho ou com renda própria deixou de ser apenas a operária, a educadora, a prestadora de serviços domésticos, a enfermeira, a assistente social. Homens passaram a enfrentar a concorrência feminina em postos de comando e em funções de elevada especialização.

$\mathrm{O}$ ingresso feminino em arenas anteriormente monopolizadas por homens não significa que tenha havido a extinção de preconceitos, mas que muitos sulcos foram abertos, abalando antigas fortalezas. Entre as carreiras de nível superior, uma das funções tradicionalmente ocupadas por homens é a de delegado de polícia. O estereótipo da profissão combina formação em ciências jurídicas com traços viris. Afinal, afirma-se, lidar com a bandidagem exige conhecimento das leis misturado a altas doses de autoridade, de força, de coragem e de capacidade de decisão - atributos supostamente masculinos.

O principal objetivo deste texto é apresentar o perfil das mulheres que conseguiram romper a barreira da exclusividade masculina e adentrar em uma das mais importantes carreiras do sistema de justiça e de segurança pública a delegada de polícia. Não se pretende discutir preconceitos ou a visão dominante na sociedade sobre a polícia ou sobre seu/sua principal agente o/a delegado/a. O objetivo é compor um retrato da mulher delegada, isto é, daquela que empunha armas e é mulher, comanda e é mulher, dá voz de prisão e é mulher, preside inquéritos e é mulher. Tratar-se-ia, de fato, de um grupo distinto no interior da Polícia Civil ou, ao contrário, as diferenças de gênero não se expressam também em outras características? Ou seja, o fato de ser mulher-delegada significaria igualmente distintas origens familiar, social e cultural? Possuiriam as integrantes do sexo feminino na carreira policial uma diferente avaliação sobre a justiça e assumiriam diferentes posições sobre as propostas para melhorar a segurança pública? Ou, ao contrário, o fato de uns pertencerem ao sexo masculino e outras ao feminino não implica diferenças significativas na caracterização socioeconômica e na percepção sobre a justiça e o sistema penal? 


\section{COMPONDO O PERFIL DAS DELEGADAS}

\section{Delegadas: uma minoria}

A carreira de delegado de polícia é expressivamente masculina. As delegadas são em número menor do que os delegados. Reproduzindo a realidade nacional, nos nove estados contemplados pela pesquisa ${ }^{2}$ - Amapá, Bahia, Distrito Federal, Goiás, Pernambuco, Paraná, Rio de Janeiro, Rio Grande do Sul e São Paulo - os homens representam a significativa maioria entre esses profissionais. Eles correspondem a 83,4\% do total de integrantes da carreira e as mulheres a apenas 16,6\%. A participação feminina, contudo, não é igualmente baixa em todas as unidades da federação. $\mathrm{O}$ maior número de mulheres está na Bahia (49\%) e no Amapá (41\%). Em contraste, a menor proporção é encontrada em São Paulo (10\%), no Paraná $(11 \%)$ e no Rio Grande do Sul (15\%). Encontram-se em situação intermediária, o Distrito Federal (19\%), Rio de Janeiro (20,5\%), Goiás $(20,7 \%)$ e Pernambuco $(23,7 \%)$.

Haveria uma explicação para essa discrepância na proporção de delegados e delegadas nos estados? A resposta não é fácil e menos ainda inequívoca. Em uma primeira aproximação, seria possível sustentar que a diferente participação de mulheres no número total de delegados apresenta uma relação com os indicadores sociais e econômicos dos estados. Efetivamente, testes estatísticos confirmam a existência de uma forte correlação negativa entre o número de mulheres e o grau de desenvolvimento das unidades da federação pesquisadas ${ }^{3}$. Isto é, quanto maiores os índices de renda, de escolaridade e de longevidade, menor a participação feminina.

Uma conclusão apressada afirmaria que estamos diante de um paradoxo, uma vez que o preconceito em relação às mulheres apareceria como menor nos estados menos desenvolvidos. Essa relação certificaria -

\footnotetext{
${ }^{2}$ A pesquisa baseou-se em escolhas que procuraram representar diferentes regiões do país, graus variados de desenvolvimento social e econômico, condições políticas diversas, bem como distintas experiências na área da polícia e segurança pública.

${ }^{3}$ Encontrou-se uma correlação de Spearman significativa (-0,80 para 1991; -0,66 para 1980 e -0,61 para 1970) indicando que quanto mais alto o IDH-M (Índice de Desenvolvimento Humano Municipal), que leva em consideração variáveis socioeconômicas (longevidade, educação e renda), menor o percentual de mulheres entre os delegados.
}

nessa leitura pouco cuidadosa - menor resistência ao ingresso de mulheres em uma ocupação profissional tradicionalmente masculina. Ou dizendo-o de outra forma: há chances mais reduzidas de encontrar maior número de delegadas nas unidades da federação com melhores indicadores no que se refere à longevidade, à educação e à renda. Interpretações mais sofisticadas, contudo, não se contentariam com essa primeira aproximação e atentariam para outros aspectos, capazes de qualificar aquela correlação. Bonelli, em artigo neste volume, sustenta a hipótese de que o grau de profissionalização da carreira é uma variável importante. Assim, nos estados em que a carreira encontra-se mais profissionalizada, ela tenderia a ser menos receptiva ao ingresso de mulheres. Anjos Bahia, por sua vez, em sua dissertação de mestrado sobre delegadas na Bahia, argumenta que a inserção da mulher no serviço policial está estreitamente relacionada a uma concepção de polícia com missões de assistência e de trabalho preventivo ${ }^{4}$.Além dessas variáveis, sem dúvida significativas, outras deveriam ser examinadas, tais como: a proporção de oferta de postos de trabalho no setor público e no privado; a grandeza da remuneração oferecida para os delegados; o diferente prestígio da carreira; as características da violência; o percentual de mulheres bacharéis em Direito; a proporção de mulheres inscritas nos concursos para delegado.

No que se refere ao salário, por exemplo, interpretações correntes defendem o argumento de que salários mais baixos afugentam os homens, deixando espaço para as mulheres. Haveria, então, uma relação entre a grandeza da remuneração e a proporção de mulheres na carreira policial? É possível verificar que não existe, de fato, uma situação salarial homogênea no país. A remuneração dos delegados varia de estado para estado. As unidades federativas podem, pois, ser ordenadas de acordo com a diversidade salarial praticada. Esse critério permite classificar os estados, obedecendo à seguinte disposição, da mais baixa para a mais alta remuneração: Bahia, Pernambuco, São Paulo, Amapá, Rio de Janeiro, Goiás, Rio Grande do Sul, Paraná e Distrito Federal. À primeira vista, a colocação da Bahia no ordenamento determinado pelo salário confirmaria a tese. Esse é o estado com a mais baixa remuneração e com a maior proporção de mulheres. O lugar ocupado pelos demais estados, porém, exigiria um exame mais acurado, sobretudo devido ao fato de São Paulo

${ }^{4}$ Maria Cândida dos Anjos Bahia, Mulheres no Comando das Organizações: Um Caso de Polícia, dissertação de mestrado, Universidade Federal da Bahia, 2002. 
estar na terceira posição e possuir o menor contingente relativo de mulheres. Teste estatístico ${ }^{5}$, contudo, aponta existir correlação entre o percentual de mulheres e a faixa salarial $(-0,20)$, sugerindo que quanto menor a faixa salarial, maior o percentual de mulheres na carreira. Destaque-se, todavia, que essa correlação não é tão forte quanto a relativa aos indicadores sociais e econômicos demonstrada acima.

Ainda no que se refere à relação entre remuneração e presença de mulheres, observou-se que, nos estados pesquisados, a faixa salarial média das delegadas difere da dos delegados nas seguintes unidades: Pernambuco, Rio de Janeiro, Rio Grande do Sul e São Paulo. Nesses estados, as mulheres não se distribuem de forma proporcional em todos os postos da carreira, havendo um percentual relativamente mais alto de delegadas nas faixas salariais inferiores, isto é, em cargos mais baixos na hierarquia policial. $\mathrm{Ou}$ seja, para uma adequada análise da participação por gênero na carreira de delegado, não bastaria examinar o ingresso e o tamanho da população feminina. Os dados aqui apresentados mostram que seria indispensável que se atentasse também para os postos ocupados pelas mulheres na hierarquia profissional. A necessidade de combinar diferentes explicações foi explicitada por uma entrevistada, ainda que seus argumentos não escondam a concordância com percepções dominantes na sociedade. Preocupada em entender o diferente grau de predomínio masculino na carreira, uma delegada em São Paulo disse:

É estranho. Mas você sabe que é bem na Bahia, que há tanto tempo é o lugar com mais mulher delegada. Bem lá, com tantos coronéis, tanto machismo... São muitos os fatores para a diferença que eu não saberia dizer o que é mais importante. Sei que nos locais em que a criminalidade é muito alta, dificilmente é grande o número de mulheres na linha de frente. Como em São Paulo tem muita violência, mais que na Bahia, entram menos mulheres. As mulheres também têm medo. As chefias acreditam que os homens são mais resistentes e impõem mais para os criminosos. Aqui, em São Paulo, por exemplo, é difícil encontrar uma mulher nas delegacias de Capão Redondo. É mais fácil encontrar delegadas em funções mais protegidas e postos menos perigosos, como as delegacias de idosos e da mulher. Sei que isto é um preconceito, mas é assim que funciona.

\footnotetext{
${ }^{5}$ Trata-se de correlação de Spearman.
}

Uma melhor compreensão da carreira de delegado dependeria, sem dúvida, da avaliação do peso e do significado de um conjunto de variáveis - algumas aqui listadas. O atual estágio de conhecimento desaconselha enfaticamente interpretações simplistas e apressadas. Seguindo essa recomendação, pode-se sustentar que, no Brasil, a carreira de delegado possui um perfil de gênero bastante diferenciado em suas distintas unidades federativas, apesar do acentuado predomínio masculino na maior parte dos estados.

Essa diversidade pode ser observada na Tabela 1, que apresenta o número total de delegados e sua composição por gênero nos estados pesquisados, bem como o número de homens e mulheres da amostra.

Como no decorrer do texto iremos trabalhar apenas com a amostra, é importante que se frise, uma vez mais, que homens e mulheres foram representados conforme sua distribuição no universo das polícias de cada estado $^{6}$

${ }^{6}$ A distribuição por gênero não foi o único critério. A amostra respeitou também a proporção de delegados em atividade na capital e nos municípios do interior. Nos estados do Rio Grande do Sul, Paraná, São Paulo e Rio de Janeiro, os municípios da região metropolitana (com exceção da capital) foram agrupados em categoria específica. Embora não tenha sido adotado como critério de estratificação da amostra, a distribuição do contingente de delegados por "classe" na carreira também foi observada. 


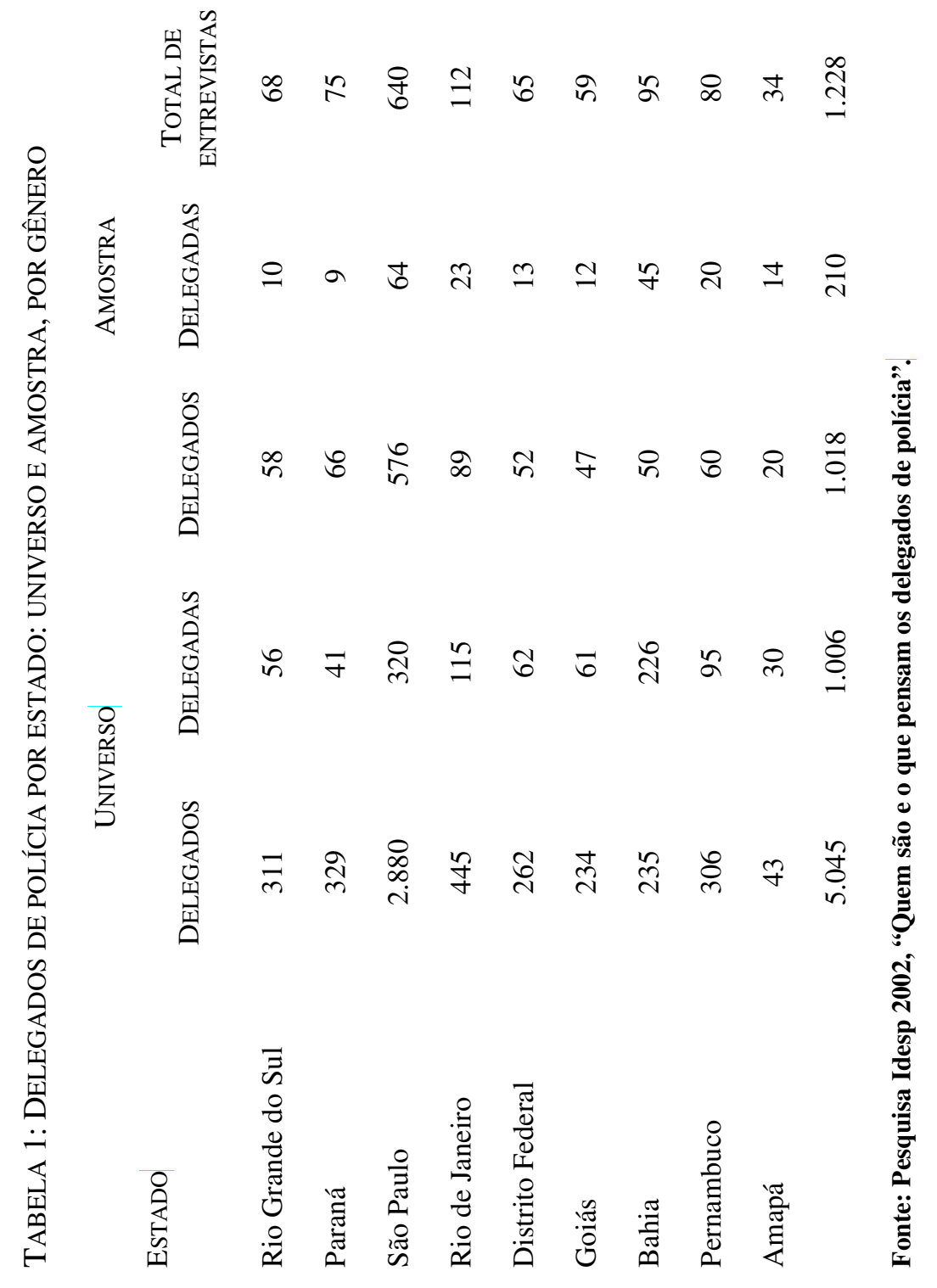

\section{Características pessoais e sociais}

As mulheres, como já afirmamos, representam $17,1 \%$ da amostra, um percentual bastante próximo do total de delegadas nos estados pesquisados $16,6 \%$.

No que se refere à idade, as delegadas são em geral mais jovens do que os delegados. Enquanto a média de idade dos homens é de 44 anos, a das mulheres é de 38. Não há grandes variações quando se observa a idade de delegados e delegadas nos estados que compõem a pesquisa. A média de idade mais baixa entre as delegadas - 35 anos - é encontrada no Rio Grande do Sul e a mais alta no Paraná - 40 anos.

Os integrantes da carreira são predominantemente de cor branca (84\%). Observe-se, contudo, que há um percentual maior de brancos entre os homens do que entre as mulheres. As delegadas distinguem-se também por apresentarem maior proporção de representantes de grupos étnicos minoritários: as pardas são 20,8\% e as amarelas 2,9\%. Esses dados podem ser apreciados na Tabela 2.

\section{TABELA 2: COR DOS ENTREVISTADOS, POR GÊNERO (EM \%)}

$\begin{array}{lccc}\text { COR } & \text { DELEGADOS } & \text { DELEGADAS } & \text { TOTAL } \\ \text { Branca } & 86,0 & 73,9 & 84,0 \\ \text { Parda } & 9,5 & 20,8 & 11,4 \\ \text { Negra } & 3,2 & 2,4 & 3,1 \\ \text { Amarela } & 1,0 & 2,9 & 1,3 \\ \text { Vermelha } & 0,2 & 0,0 & 0,2 \\ \text { Não informou } & 0,1 & 0,0 & - \\ \text { TOTAL } & 100,0 & 100,0 & 100,0\end{array}$

Fonte: Pesquisa Idesp, 2002, “Quem são e o que pensam os delegados de polícia”.

A cor distingue o grupo feminino do masculino no geral da amostra e também nos estados. O menor percentual de delegadas brancas está no Amapá. Ali, elas são apenas $30,8 \%$, enquanto as pardas alcançam a expressiva participação de $69,2 \%$. A mesma distribuição de cor não se dá entre os delegados: $60 \%$ são brancos, $35 \%$ pardos e $5 \%$ negros.

Contrastando com a distribuição de cor do Amapá, todas as delegadas nos estados do Paraná e do Rio Grande do Sul são brancas. Isso 
não se repete entre os homens. Pois, embora a maior proporção de homens brancos esteja no Rio Grande do Sul e em São Paulo, não se trata da totalidade, mas de cerca de $95 \%$. No caso do Paraná, há $9 \%$ de delegados pardos e $6 \%$ de negros.

O Distrito Federal e a Bahia possuem o quadro mais plural no que se refere à cor dos integrantes da carreira. No DF, são 69,2\% de brancas, $15,4 \%$ de pardas, $7,7 \%$ de amarelas e 7,7\% de negras. Entre os delegados, $58 \%$ são brancos, $38,5 \%$ pardos, $2 \%$ negros e $2 \%$ amarelos. Na Bahia, um pouco mais da metade das delegadas $(51,1 \%)$ disseram-se pardas, contra $42 \%$ dos delegados; há igual percentual de brancos entre os homens e as mulheres (38\%); os negros são proporcionalmente mais numerosos entre os delegados $(16 \%)$ do que entre as delegadas $(8,9 \%)$ e $4 \%$ dos homens e $2,2 \%$ das mulheres são amarelos.

Quanto à naturalidade, observa-se que a maioria expressiva das delegadas, mais do que entre os delegados, nasceu no mesmo estado em que exerce a profissão. Efetivamente, a comparação da mobilidade geográfica de homens e mulheres revela que, embora seja, em geral, muito baixa a migração, as mulheres, em todos os estados, com exceção do Rio Grande do Sul, são mais oriundas da própria unidade da federação em que atuam do que os homens. Esse cotejo pode ser observado na Tabela 3, que indica o percentual de delegados e delegadas que desempenham a atividade profissional no mesmo estado de nascimento.

Chama a atenção no estado do Rio Grande do Sul o fato de nenhum delegado ser proveniente de outro estado. Contudo, das dez mulheres entrevistadas no Rio Grande do Sul, duas não eram gaúchas mas tinham origem em Santa Catarina, um estado geograficamente muito próximo. Os mais baixos percentuais de nascidos no próprio estado encontram-se no Amapá e no Distrito Federal. Destaca-se, ainda, a distinta situação de naturalidade de homens e mulheres observada em Goiás. Naquela unidade da federação, enquanto $83,3 \%$ das delegadas ali nasceram, essa proporção se reduz para quase a metade no que se refere aos delegados $(48,9 \%)$.

Quanto ao estado civil, como mostra a Tabela 4, a maior parte dos integrantes da carreira é constituída por casados. Nota-se, entretanto, uma diferença significativa entre os homens e as mulheres. Enquanto 76,8\% dos delegados dizem-se casados, esse percentual cai para apenas $47,8 \%$ entre as mulheres. De forma complementar, é maior a proporção de delegadas solteiras - 31,6\% contra somente $13,5 \%$ entre os homens - e separadas $(18,7 \%$ das mulheres e $9,5 \%$ dos homens). Provavelmente, esses percentuais são indicadores da dificuldade de conciliar a vida profissional com a vida privada nos moldes tradicionais. Em entrevistas, algumas delegadas disseram que grande parte dos homens sente-se pouco confortável em namorar, noivar e casar com uma mulher cuja profissão implica dar ordens, inquirir e empunhar um revólver. Perguntada sobre essa questão, disse uma delegada em São Paulo: "A dificuldade começa em ter um namorado. Os homens ainda pensam na mulher como o sexo frágil. $\mathrm{O}$ fato de ser delegada não significa que você não é feminina. Mas, para nós, é mais difícil conviver com um machão". Uma delegada entrevistada por Anjos Bahia afirmou: "Já perdi namorados por conta da discriminação. No começo eles não acreditam, mas quando veem que é verdade, às vezes, caem fora". Uma outra assim se manifestou:

Meu marido não aceita minha profissão. Depois que me tornei delegada nossa relação vem piorando. Agora que tenho um filho, não dá para deixar certas coisas de lado. A reação de meu marido não é brigar, mas retaliar, pirraçar, boicotar, deixar as atividades domésticas para mim. Vou administrando conforme a prioridade. É um estresse! Mas agora vou levando fingindo que não ouço suas provocações (Anjos Bahia, op. cit., p.122).

TABELA 3: PROPORÇÃO DE DELEGADOS E DELEGADAS QUE ATUAM NO ESTADO EM QUE NASCERAM

$\begin{array}{lcc}\text { ESTADO } & \text { DELEGADOS } & \text { DELEGADAS } \\ \text { Amapá } & 30,0 & 35,7 \\ \text { Bahia } & 92,0 & 93,3 \\ \text { Distrito Federal } & 21,2 & 38,5 \\ \text { Goiás } & 48,9 & 83,3 \\ \text { Pernambuco } & 83,3 & 95,0 \\ \text { Paraná } & 65,2 & 66,7 \\ \text { Rio de Janeiro } & 84,3 & 95,7 \\ \text { Rio Grande do Sul } & 100,0 & 80,0 \\ \text { São Paulo } & 94,3 & 95,3\end{array}$

Fonte: Pesquisa Idesp, 2002, “Quem são e o que pensam os delegados de polícia”. 
TABELA 4: ESTADO CIVIL DOS ENTREVISTADOS, POR GÊNERO (EM \%)

$\begin{array}{lccr} & \text { DELEGADOS } & \text { DELEGADAS } & \text { TOTAL } \\ \text { Solteiro } & 13,5 & 31,6 & 16,6 \\ \text { Casado/união conjugal } & 76,8 & 47,8 & 71,9 \\ \text { Separado/divorciado/desquitado } & 9,5 & 18,7 & 11,0 \\ \text { Viúvo } & 0,2 & 1,9 & 0,5\end{array}$

Fonte: Pesquisa Idesp, 2002, “Quem são e o que pensam os delegados de polícia”.

As diferenças relativas ao estado civil de delegados e delegadas são observadas em todos os estados. Desperta a atenção, entretanto, o significativo percentual de casados no Amapá, tanto entre os homens (90\%) como entre as mulheres $(69,2 \%)$. Por outro lado, a menor proporção de delegadas casadas é encontrada no Rio de Janeiro $(26,1 \%)$ e em Goiás $(33,3 \%)$. O número de delegadas separadas é relativamente menor no Rio Grande do Sul (10\%) e chega a 25\% das integrantes da carreira em Goiás, em Pernambuco e no Rio de Janeiro.

Entre as delegadas casadas, a maioria $(61 \%)$ possui cônjuge com igual nível de escolaridade - grau universitário. Nesse aspecto, destacam-se as profissionais atuando em Goiás, apresentando alta proporção de delegadas com maridos $(85,7 \%)$ com título universitário. Em contraste, aparece um grupo expressivo de delegadas pernambucanas (54\%) convivendo com parceiros com menor escolaridade formal do que elas.

No que se refere a filhos, um significativo percentual de delegadas $(34,3 \%)$ afirmou não ser mãe. Já entre os delegados, apenas $15 \%$ não são pais. Entre as delegadas que têm filhos, a maioria possui dois.

Quanto ao grau de escolaridade paterna e materna, também foi possível perceber diferenças entre os delegados e as delegadas. Essas informações constam da Tabela 5.

É visível que houve mobilidade educacional ascendente dos integrantes da carreira, exercendo uma profissão que requer o título de bacharel em Direito. Note-se que $70,1 \%$ dos pais e $78,4 \%$ das mães dos entrevistados não possuem curso universitário. Tanto no caso dos delegados como das delegadas, os pais, em média, obtiveram mais educação formal do que as mães. Apesar dessas semelhanças, há diferenças significativas entre homens e mulheres no que se refere ao grau de escolaridade paterna e materna. É visivelmente maior a proporção de delegadas oriundas de famílias cujos pais e mães ostentam grau universitário completo. Inversamente, entre as delegadas, a proporção de pais e mães sem escolaridade formal é a metade ou menos ainda da encontrada entre os delegados.

\section{TABELA 5: GRAU DE INSTRUÇÃO DOS PAIS, POR GÊNERO (EM \%)}

PAI

\begin{tabular}{|c|c|c|c|c|}
\hline & & \\
\hline & DELEGADOS & DELEGADAS & DELEGADOS & DELEGADAS \\
\hline Sem instrução formal & 6,6 & 3,4 & 7,7 & 2,5 \\
\hline $1^{\circ}$ grau incompleto & 23,0 & 17,8 & 22,3 & 17,9 \\
\hline $1^{\circ}$ grau completo & 17,7 & 13,5 & 20,9 & 18,9 \\
\hline $2^{\circ}$ grau incompleto & 5,8 & 4,8 & 6,5 & 4,0 \\
\hline $2^{\circ}$ grau completo & 16,4 & 22,1 & 23,2 & 30,8 \\
\hline Universitário incompleto & 3,2 & 2,4 & 2,2 & 3,5 \\
\hline Universitário completo & 27,3 & 36,1 & 17,3 & 22,4 \\
\hline
\end{tabular}

Fonte: Pesquisa Idesp, 2002, “Quem são e o que pensam os delegados de polícia”.

As diferenças no nível educacional de pais e mães de delegados e delegadas conferem informações preciosas sobre o perfil familiar dos integrantes da carreira. Por essa razão vale a pena abrir espaço para descrever as variações entre os estados pesquisados, salientando alguns contrastes.

No Amapá, por exemplo, nenhum pai de delegada chegou a cursar a universidade; $30,8 \%$ possuem primeiro grau incompleto; $15,4 \%$ não têm instrução formal; $15,4 \%$ terminaram apenas o primeiro grau; $7,7 \%$ não chegaram até o final do segundo grau. As mães têm, no geral, mais escolaridade do que os pais. Assim, 46,2\% possuem o segundo grau completo, enquanto $30,8 \%$ não completaram o primeiro grau; $7,7 \%$ não têm instrução formal e igual percentual possui o título universitário. Comparativamente, pais e mães de delegados possuem menos escolaridade formal do que os ascendentes das delegadas. Pouco mais da metade $(55,6 \%)$ de mães dos delegados não terminaram o primeiro grau e $22,2 \%$ têm esse nível de ensino; $47,4 \%$ dos pais não chegaram ao segundo grau.

Em Goiás, 36,2\% dos pais de delegados e 58,4\% dos pais de delegadas não possuem o primeiro grau. Esses percentuais são ainda mais altos no que se refere às mães: $46,6 \%$ e $50 \%$, respectivamente. 
Na Bahia, as delegadas, em média, vêm de famílias de mais alto capital educacional do que os delegados: $34,1 \%$ dos pais das delegadas têm diploma universitário, enquanto esse percentual cai para $20,8 \%$ entre os delegados; $13,7 \%$ dos pais de delegadas não possuem o primeiro grau contra $23 \%$ dos delegados; $9,3 \%$ das mães de delegadas não completaram o primeiro grau contra $20,9 \%$ dos delegados.

Os integrantes da carreira policial no Distrito Federal têm uma situação relativamente semelhante aos da Bahia no que se refere à educação paterna. Assim, 44\% dos pais dos delegados e 23,1\% dos pais das delegadas não têm o primeiro grau; $20 \%$ dos pais dos delegados e $61,5 \%$ das mães concluíram a universidade. Quanto à escolaridade materna, há menos disparidades entre delegados e delegadas: $42,9 \%$ das mães de delegados e 38,5\% das mães de delegadas não concluíram o primeiro grau; $14,3 \%$ das progenitoras de delegados e 15,4\% das de delegadas possuem diploma universitário.

Em Pernambuco, 33,4\% dos pais dos delegados e 30\% dos pais das delegadas não têm o primeiro grau. Esses percentuais são parecidos no que diz respeito às mães: $37,6 \%$ e $27,3 \%$. Diploma universitário foi obtido por $21,7 \%$ dos pais de delegados, mas por $30 \%$ dos pais de delegadas. Da mesma forma, demonstrando que maior parcela de delegadas tem origem em famílias de mais alta educação formal, 36,8\% entre elas têm mães com nível universitário contra apenas $12,1 \%$ dos delegados.

Delegados e delegadas atuando no estado do Paraná não se diferenciam no que se refere ao grau de escolaridade paterna: a mesma proporção de homens e mulheres tem pais com diploma universitário $22,2 \%$. É também muito semelhante o percentual de pais sem o primeiro grau entre os integrantes dos dois gêneros - 41,2\% dos delegados e 44,4\% das delegadas. Já no que diz respeito às mães, tem-se um quadro diferente: $36,1 \%$ das mães dos delegados não têm o primeiro grau contra $55,5 \%$ das mães de delegadas; $14,5 \%$ dos delegados e $22,2 \%$ das delegadas possuem mães com nível universitário.

É muito distinta a situação familiar educacional de delegados e delegadas no Rio Grande do Sul. Enquanto 35,1\% dos homens possuem pais sem o primeiro grau completo, esse percentual cai para $20 \%$ entre as mulheres. Da mesma forma, é praticamente o dobro a proporção de pais de delegadas com nível universitário (40\%) quando comparada aos de delegados $(24,6 \%)$. Já no que se refere à escolaridade materna, encontramse semelhanças: $41,3 \%$ e $40 \%$ das mães de delegados e delegadas, respectivamente, não concluíram o primeiro grau. É, porém, maior o percentual de mães de delegadas que continuaram os estudos após o segundo grau - 30\% - contra menos da metade $(13,8 \%)$ entre os delegados.

Os integrantes da carreira atuando no Rio de Janeiro e em São Paulo ostentam uma origem familiar em termos educacionais muito parecida. Os dois estados concentram a maior proporção de pais de delegados e delegadas com o mais alto nível de escolaridade. O mesmo pode ser constatado para as mães de delegados, mas não para as mães de delegadas no estado de São Paulo. No Rio de Janeiro, 32,6\% dos pais e 21,4\% das mães de delegados possuem diploma universitário. Entre as mulheres esses percentuais são mais altos: $52,2 \%$ dos pais e $34,8 \%$ das mães de delegadas têm esse título. Em São Paulo, 30,2\% dos pais e $18,9 \%$ das mães de delegados; e $43,8 \%$ dos pais e $25,4 \%$ das mães de delegadas cursaram a universidade.

Indicando também traços sobre o ambiente vivido na casa paterna e materna, nota-se que a maioria expressiva dos delegados e delegadas exerceu alguma atividade profissional antes de ingressar na carreira $(92,3 \%)$. Apenas $7,6 \%$ afirmaram não ter exercido nenhuma atividade anteriormente. $\mathrm{O}$ exame desse aspecto, segundo o gênero do entrevistado, pode ser apoiado nos dados apresentados na Tabela 6 .

TABELA 6: EXERCÍCIO DE ATIVIDADE PROFISSIONAL ANTERIOR, POR GÊNERO (EM \%)

$\begin{array}{lccc} & \text { DELEGADOS } & \text { DELEGADAS } & \text { TOTAL } \\ \text { Não } & 5,9 & 15,7 & 7,6 \\ \text { Sim } & 94,1 & 84,3 & 92,4 \\ \text { TOTAL } & 100,0 & 100,0 & 100,0\end{array}$

Fonte: Pesquisa Idesp, 2002, “Quem são e o que pensam os delegados de polícia”.

Supondo-se que famílias com renda maior têm condições de postergar a entrada de seus filhos no mercado de trabalho, as delegadas desfrutaram de uma situação mais favorável do que os delegados. Uma proporção três vezes maior de mulheres do que de homens não trabalhou antes de exercer a atividade policial. $\mathrm{O}$ maior percentual de mulheres que não desempenhou atividade profissional anterior é encontrado em 
Pernambuco. Ali, duas em cada dez delegadas não tiveram que trabalhar antes de iniciar a carreira policial. No extremo oposto estão as profissionais do Paraná. Nesse estado, nenhuma delegada ficou fora do mercado antes de se tornar policial. Todas disseram ter trabalhado anteriormente. Em seguida aparece o Rio Grande do Sul: entre as delegadas gaúchas, nove em cada grupo de dez trabalharam antes de ingressar na carreira.

Observando-se o ano de ingresso na carreira, percebe-se que a presença de um número maior de mulheres na polícia é fenômeno recente, uma vez que quase a metade do quadro feminino ingressou depois de 1995, enquanto apenas $22,3 \%$ dos homens entrevistados ingressaram a partir dessa data. Esse fenômeno foi particularmente notado nos estados de Goiás, Bahia, Pernambuco, Rio de Janeiro, Rio Grande do Sul e São Paulo. Nos outros estados - Amapá, Distrito Federal e Paraná - não foram encontradas diferenças estatisticamente significativas ${ }^{7}$ entre os dois gêneros, em relação ao ano de ingresso.

É comum ouvir que relacionamentos familiares influenciam a escolha profissional e, mais ainda, que, no caso de mulheres, essas tendem a seguir a carreira materna ou paterna. Com a preocupação de mapear a existência ou não de parentes na Polícia Civil, arguiu-se os entrevistados sobre essa questão. As respostas estão sistematizadas na Tabela 7.

\section{TABELA 7: PARENTES NA POLÍCIA CIVIL, POR GÊNERO (EM \%)}

$\begin{array}{lccc} & \text { DELEGADOS } & \text { DELEGADAS } & \text { TOTAL } \\ \text { Não } & 61,6 & 63,3 & 61,9 \\ \text { Sim } & 38,4 & 36,7 & 38,1 \\ \text { Fonte: Pesquisa Idesp, 2002, “Quem são e o que pensam os delegados de polícia”. }\end{array}$

Entre os integrantes da carreira, a maioria $(61,9 \%)$ não tem parentes na Polícia Civil enquanto $38,1 \%$ têm, indicando a proporção de recrutamento exógeno e endógeno, respectivamente. No geral, não há diferenças quanto a esse aspecto entre delegados e delegadas. Observandose, no entanto, a realidade de cada estado, nota-se situações muito variadas. Assim, no Amapá, enquanto $75 \%$ dos delegados não têm parentes na Polícia Civil, esse número reduz-se para dois quartos entre as delegadas.

\footnotetext{
${ }^{7}$ Trata-se de teste $t$ de Student, a 5\%
}

Também na Bahia, em Pernambuco e em São Paulo é maior a proporção de delegadas do que a de delegados com parentes na corporação, ainda que esse percentual seja sempre mais reduzido do que o relativo ao grupo sem nenhum parentesco. A situação das delegadas atuando no Paraná destoa das demais. Ali está a maior proporção de mulheres com parentes na Polícia Civil - 77,8\%. Em forte oposição ao quadro paranaense e diferentemente do que ocorre nos demais estados, no Rio Grande do Sul nenhuma das delegadas possui parentes com vínculos com a Polícia Civil.

\section{PERFIL PROFISSIONAL}

As características pessoais e sociais - idade, cor, naturalidade, estado civil, número de filhos, escolaridade paterna e materna, atividade profissional antes de entrar na Polícia Civil, ano de ingresso na carreira, parentesco na instituição - compõem dois retratos distintos: o da delegada e o do delegado. Certamente, não se trata de dois opostos. Para além da diferença de gênero, há singularidades que distinguem a delegada mulher: mais jovem, menos branca, com menor mobilidade geográfica, mais solteira e separada, filha de pais com maior escolaridade, mais protegida pela família, tem menos filhos, ingressou mais recentemente na carreira e possui mais parentes na instituição. Restaria saber se essas diferenças também se expressam em suas percepções e opiniões sobre a carreira do delegado de Polícia (aspectos valorizados e motivos que as levaram a adotar essa profissão), sobre os obstáculos ao bom funcionamento da Polícia Civil e propostas para melhorar o desempenho da atividade policial, do sistema de segurança pública e para diminuir a impunidade e a criminalidade.

\section{Traços valorizados em um bom delegado}

O modelo ideal do profissional delegado é diferente para os homens e para as mulheres. Para os delegados, os traços mais importantes obedecem à seguinte prioridade: capacidade de preparar inquéritos bem circunstanciados, saber jurídico, competência técnica para o trabalho de investigação, saber trabalhar em equipe, habilidade para lidar com situações de risco, aptidão para chefia e liderança, obediência irrestrita aos direitos humanos, ser reconhecido pelos pares. Já para as delegadas, o quesito mais valorizado é o saber jurídico; em seguida aparecem a capacidade de preparar inquéritos bem circunstanciados, saber trabalhar em equipe, 
competência técnica para o trabalho de investigação, habilidade para lidar com situações de risco, aptidão para chefia e liderança, obediência irrestrita aos direitos humanos e reconhecimento pelos pares.

TABELA 8: CARACTERÍSTICAS VISTAS COMO “MUITO IMPORTANTES" PARA SER BOM DELEGADO, POR GÊNERO (EM \%)

Capacidade de preparar inquéritos bem

circunstanciados

Saber jurídico

Competência técnica para o trabalho de

investigação

Saber trabalhar em equipe

Habilidade para lidar com situação de

risco, violência

Aptidão para exercer chefia e liderança

Obediência irrestrita aos direitos

humanos

Ser reconhecido pelos pares

\begin{tabular}{ccr}
81,9 & 83,3 & 82,2 \\
78,9 & 87,1 & 80,3 \\
78,2 & 74,8 & 77,6 \\
74,6 & 78,5 & 75,3 \\
71,8 & 71,9 & 71,8 \\
70,7 & 68,6 & 70,3 \\
58,9 & 54,3 & 58,1 \\
31,7 & 25,6 & 30,6 \\
\hline
\end{tabular}

Fonte: Pesquisa Idesp, 2002, “Quem são e o que pensam os delegados de polícia”.

Como se apreende da Tabela 8, que hierarquiza as qualidades do bom delegado, segundo a opinião de homens e mulheres, as delegadas tendem a dar mais importância do que os homens ao saber jurídico, à preparação de inquéritos bem circunstanciados e a saber trabalhar em equipe. Por outro lado, as delegadas atribuem menor importância do que os delegados às seguintes qualidades: competência técnica para o trabalho de investigação, aptidão para exercer chefia e liderança, obediência aos direitos humanos, reconhecimento pelos pares. De todos os atributos, o único que recebeu o mesmo grau de importância para homens e mulheres é a habilidade para lidar com situações de risco.

É provável que a diferença de quase dez pontos percentuais na atribuição de importância ao saber jurídico entre as mulheres reflita maior valorização do quesito que permitiu o seu ingresso na carreira. Por outro lado, o menor destaque conferido ao reconhecimento pelos pares deve ter a ver com o fato de o grupo feminino constituir-se minoria e também ao pouco peso do mérito na ascensão dos degraus da hierarquia - critério, sublinhe-se, pouco considerado tanto por parte dos homens como pelas mulheres.

Sobre essas questões, disse-nos uma delegada de São Paulo:

Você sabe que a mulher para se destacar tem que saber mais que o homem. Quando eu prestei concurso, me lembro que, da minha turma da faculdade, quinze prestaram o exame. Desses, dez eram homens e cinco mulheres. Todas as mulheres passaram, dos homens só dois. Nós estudamos mais, porque sabemos que nosso valor só é reconhecido na competência. [...] $\mathrm{Na}$ nossa profissão, depois que você entra, o conhecimento das leis deixa de ser tão importante. Não deveria ser assim, mas é. Além disso, como só se sobe na carreira com influência, não importa muito sua competência.

A maior valorização da importância do saber jurídico por parte das delegadas foi observada em todos os estados, com exceção do Distrito Federal. Em Pernambuco, todas as entrevistadas consideraram esse aspecto muito importante.

No que se refere à obediência irrestrita aos direitos humanos, o percentual mais alto de delegadas considerando essa característica muito importante está no Amapá e o mais baixo em Goiás (33,3\%). Já entre os homens, as mais altas proporções estão na Bahia $(64,0 \%)$ e em Pernambuco $(63,8 \%)$ e as mais baixas no Rio Grande do Sul $(43,9 \%)$ e em Goiás $(45,7 \%)$.

\section{Motivos que levaram a ingressar na carreira}

Sabe-se que é difícil determinar um único fator como responsável pela decisão de ingressar em uma determinada carreira. Em geral, há a confluência de uma série de motivos, dos mais idealistas aos mais práticos. A despeito dessa dificuldade, é possível classificar as razões em altruístas e egoístas. Por outro lado, na dimensão simbólica, a vocação feminina é recheada de atributos relacionados à dedicação, à compaixão, à prestação de serviços para a comunidade, entre outros - traços condizentes com um modelo estruturado em razões de ordem altruística. Comporiam, assim, o estereótipo da imagem feminina uma série de substantivos e adjetivos que a afastam do mundo material, das vantagens pecuniárias, aproximando a mulher de tudo que se contraponha ao interesse mais imediato. Vejamos, pois, se há de fato uma 
diferença significativa entre os motivos que levaram os homens e as mulheres a optar pela carreira policial. Esses dados constam da Tabela 9.

TABELA 9: FATORES QUE INFLUENCIARAM A DECISÃO DE SER DELEGADO, POR GÊNERO (EM \%)
Defesa do cidadão

Oportunidade de prestar

serviços à comunidade

Estabilidade do cargo

público

Experiência anterior na

polícia

Remuneração

Prestígio e

Parentes/conhecidos que

trabalhavam na segurança

pública

Falta de opção no

mercado de trabalho

Professores na faculdade reconhecimento

\section{MUITO IMPORTANTE}

Delegados DELEGADAS 45,4

48,2

36,4

$$
37,5
$$$$
19,8
$$

9,7

8,8

1,6
IMPORTANTE Delegados Delegadas $47,4 \quad 43,7$ $48,0 \quad 51,0$

$15,8 \quad 4,6$

$52,7 \quad 41,6$

$41,2 \quad 23,6$

e demonstram desprendimento. A veracidade desse argumento nos obrigaria a interpretar com alguma reserva respostas que traduzissem esse tipo de inclinação. De toda forma, o caráter universal da tendência de ver como positivo motivos de natureza altruísta abrandaria um possível viés.

A maior parte dos integrantes da carreira, independentemente do sexo, considerou muito importante a alternativa "defesa do cidadão", aparecendo em seguida a "oportunidade de prestar serviços à comunidade". Dois motivos altruístas, sem dúvida. Notar-se-ia, contudo, diferenças significativas na adesão a esses motivos quando se contrasta as opções de delegados e as de delegadas?

Para testar a hipótese de que haveria maior grau de altruísmo entre as mulheres, foram criadas duas escalas e aplicado teste estatístico não paramétrico $^{8}$. Dessa forma foi possível verificar que não existe diferença relevante nos motivos apresentados por delegados e delegadas. Isto é, não se sustenta a afirmação segundo a qual as mulheres se pautariam por motivos mais altruístas do que os homens. E, de forma complementar, não é igualmente aceitável a suposição segundo a qual os homens se orientam por razões relacionadas sobretudo a seus interesses pessoais e materiais.

Pode-se concluir, outrossim, que, mesmo quando se considera cada um dos fatores isoladamente, não há diferenças significativas entre as repostas dadas pelas mulheres e pelos homens ${ }^{9}$.

A ausência de diferenças significativas quanto aos fatores que influenciaram a decisão de ser delegado não significa que não haja aspectos a se ressaltar. Assim, caberia salientar que é alto o reconhecimento da importância da estabilidade do cargo público, tanto entre os homens como entre as mulheres, bem como é significativa a proporção dos que admitem a influência da remuneração na decisão de ingressar na carreira policial em ambos os gêneros.

${ }^{8}$ Trata-se de teste Mann-Whitney. A média de "altruísmo" para as mulheres foi de 1,68 e a dos homens 1,74. No que se refere ao "egoísmo", encontrou-se médias de 2,53 e de 2,54 para mulheres e homens, respectivamente.

${ }^{9}$ Foi feito o teste de chi-quadrado para cada um dos percentuais nas distintas alternativas. Também segundo essa estatística não foram observadas diferenças significativas entre os percentuais relativos às respostas dos homens e das mulheres. 
Por outro lado, apareceram como fatores menos importantes para a escolha da profissão a falta de opção no mercado de trabalho e a influência dos professores na faculdade. Embora um maior percentual de delegadas tenha parentes que trabalham ou trabalharam na Segurança Pública, elas atribuem relativamente ainda menos importância para esse aspecto do que os delegados.

A experiência anterior na polícia imprime uma importante diferença entre os delegados e as delegadas. Como se observa pelas respostas, esse fator é muito mais significativo para os homens do que para as mulheres (31,4\% versus $19,8 \%$, respectivamente).

Observando-se as singularidades estaduais, conviria salientar os seguintes aspectos:

a. Os maiores percentuais de delegadas apontando "a defesa do cidadão" como muito importante na decisão de ingressar na carreira estão no Amapá $(84,6 \%)$ e em Goiás $(72,7 \%)$ e os mais baixos no Rio Grande do Sul $(33,3 \%)$ e em São Paulo $(35,9 \%)$

b. Goiás distingue-se também por apresentar a mais alta proporção de delegadas que considera a oportunidade de prestar serviços à comunidade muito importante $(63,6 \%)$. A menor proporção referente a essa alternativa está no Paraná $(22,2 \%)$.

c. A estabilidade no emprego foi vista como muito importante por $61,9 \%$ das delegadas no Rio de Janeiro, em seguida estão as do Distrito Federal (61,5\%). A maioria das delegadas do Amapá, diferentemente, disse que esse aspecto não teve nenhuma importância na decisão.

d. Metade das delegadas da Bahia, $43,8 \%$ das de São Paulo e $20 \%$ das do Rio de Janeiro afirmaram que a remuneração foi um fator pouco ou sem importância na decisão de ingressar na carreira.

e. $75 \%$ das delegadas do Rio Grande do Sul conferiram pouca importância ao prestígio como um fator na decisão de ingressar na carreira.

\section{Avaliação da Polícia Civil}

Tornou-se lugar comum a constatação de que a Polícia Civil apresenta problemas. Há, contudo, sérias divergências quanto ao diagnóstico sobre essa crise. Ademais, é insuficiente o que se sabe sobre como os próprios integrantes da instituição avaliam a Polícia Civil e como hierarquizam os diferentes obstáculos. Os percentuais relativos ao peso atribuído por delegados e delegadas a cada um dos aspectos pode ser observado na Tabela 10.

Entre os fatores que têm representado obstáculos ao bom funcionamento da Polícia Civil o conjunto de integrantes da carreira policial apontou, em primeiro lugar, a falta de empenho governamental na implementação de políticas de Segurança e, em seguida, a interferência política na cúpula da instituição. Delegados e delegadas não se distinguem na seleção e no peso dado aos dois principais aspectos entendidos como obstáculos ao bom funcionamento da Polícia Civil. Ambos julgam que esses são os problemas mais importantes e não há diferenças significativas entre as duas proporções ${ }^{10}$.

TABELA 10: OBSTÁCULOS VISTOS COMO “MUITO IMPORTANTES” AO BOM FUNCIONAMENTO DA POLÍCIA CIVIL, POR GÊNERO (EM \%)

Falta de empenho governamental na implementação de políticas de segurança

Interferência política na cúpula da instituição

Ocupação do cargo de Secretário de Segurança por

leigos em segurança pública

Baixos salários

Formação deficiente dos policiais civis

Instabilidade no exercício do cargo de delegado

Formação deficiente dos delegados

"Bicos" e outras atividades

Interferência do Ministério Público na atividade

policial

Conflito de atuação com a Polícia Militar

Delegados Delegadas

$\begin{array}{ll}77,2 & 72,1 \\ 73,6 & 71,6 \\ 73,3 & 65,5 \\ 68,0 & 71,2 \\ 62,5 & 68,9 \\ 53,8 & 46,6 \\ 49,6 & 59,5 \\ 37,9 & 36,3 \\ 35,1 & 25,9 \\ 26,8 & 18,4\end{array}$

Fonte: Pesquisa Idesp, 2002, “Quem são e o que pensam os delegados de polícia”.

Essa semelhança, contudo, se desfaz quando se trata de julgar a hipótese de ocupação do cargo de Secretário de Segurança por leigos em Segurança Pública. Maior proporção de delegados do que de delegadas avalia que esse aspecto representa um obstáculo muito importante para o

${ }^{10}$ Teste de chi-quadrado a 5\% de significância. 
desempenho da instituição. Os dois grupos também apresentam diferenças estatisticamente significativas ${ }^{11}$ no peso concedido à formação deficiente de delegados - as mulheres atribuem mais importância a esse fator; bem como na interferência do Ministério Público na atividade policial e no conflito de atuação com a Polícia Militar - aspectos proporcionalmente mais indicados pelos homens do que pelas mulheres.

Os demais obstáculos foram vistos de forma muito semelhante por delegados e por delegadas. Isso nos permite concluir que, no geral, há mais pontos em comum do que discordâncias. Em um total de dez itens, há acordo sobre seis e divergência em quatro, sendo muito próxima a hierarquização estabelecida pelos dois grupos do aspecto mais ao menos relevante.

Um dos obstáculos ao bom funcionamento da Polícia Civil, formação deficiente dos delegados, merece destaque por corresponder a uma autocrítica - traço pouco usual em profissionais e corporações. Observe-se que esse aspecto foi apontado como muito importante por cerca de cinco em cada dez delegados e por seis em dez delegadas. Como seria de se esperar, há expressivas diferenças entre os estados. Entre os homens, a maior proporção de críticos está no Amapá e em Pernambuco. Já entre as delegadas, em geral mais críticas do que os delegados, os maiores percentuais estão igualmente no Amapá e em Pernambuco, mas também na Bahia e no Distrito Federal. Em contraste, encontra-se em São Paulo a menor proporção de delegadas que julga esse aspecto muito crucial.

Quanto à interferência política - item apontado em segundo lugar -, saliente-se que, enquanto metade dos delegados que atuam no Distrito Federal apontou esse problema como muito importante, todas as delegadas enquadraram tal obstáculo nessa categoria. Entre as mulheres, as que menos valorizaram esse aspecto estão em São Paulo (54,7\%), distanciando-se nesse particular, significativamente, da avaliação de seus colegas do sexo masculino $(73,3 \%)$.

Um tema bastante correlato à interferência política é o que diz respeito à nomeação do Secretário de Segurança - a princípio a pasta de governo mais diretamente relacionada aos delegados. Entre os integrantes da carreira, a maior proporção de delegados que se posicionou contra a ocupação do posto de Secretário de Segurança por profissionais leigos está em São Paulo $(78,4 \%)$ e a menor na Bahia $(53,1 \%)$. Já entre as delegadas, o maior percentual de contrárias a essa possibilidade localiza-se no Amapá $(78,6 \%)$ e o menor no Rio de Janeiro e em Goiás, reunindo a metade das integrantes nos dois estados.

A relevância da questão salarial como obstáculo ao bom funcionamento da Polícia Civil coloca em posições muito diferentes as delegadas da Bahia e do Rio Grande do Sul. Enquanto 83,7\% das primeiras julgam esse aspecto muito importante, apenas $33,3 \%$ da gaúchas sustentam a mesma opinião. Entre os delegados, o maior contraste está entre os entrevistados no Amapá e os de Goiás. Para $85 \%$ dos que desempenham suas atividades no Amapá, esse tema é visto como um entrave significativo, enquanto esse percentual reduz-se para menos da metade $(31,8 \%)$ entre os atuam em Goiás.

Os conflitos interinstitucionais também são apreciados de forma diferenciada nos diferentes estados. A relação com a Polícia Militar é vista como mais problemática entre os delegados do Rio Grande do Sul (37,9\%) e também as delegadas do Distrito Federal $(38,5 \%)$ e como um aspecto sem muita relevância pelos delegados da Bahia $(40,8 \%)$ e, curiosamente, pelas delegadas do Rio Grande do Sul $(44,4 \%)$. Já, no que se refere ao Ministério Público, as avaliações colocam em posições distantes os delegados do Rio Grande do Sul - onde exatamente a metade julga negativamente a interferência do Ministério Público - e os de Pernambuco (17,5\%). Entre as delegadas, as de Goiás $(58,3 \%)$ contrastam significativamente com as do Rio de Janeiro, estado no qual apenas $9,1 \%$ das profissionais acreditam que a interferência do MP constitui-se em obstáculo muito importante.

A descrição do conjunto das avaliações permite afirmar que não há um padrão de julgamento homogêneo e repetitivo, quer entre os integrantes dos estados quer entre os gêneros. As variações encontradas não se resumem a diferenças entre os diversos estados e menos ainda a distinções baseadas no gênero dos entrevistados. Em outras palavras, as diferenças de opinião entre os integrantes da carreira de delegado de polícia não podem ser imputadas ao fato de uns serem homens e outras mulheres, ou ao fato da atuação dar-se em distintas localidades.

\footnotetext{
${ }^{11}$ Referimo-nos a diferenças detectadas pelo teste de chi-quadrado a 5\%.
} 


\section{Avaliação de propostas ${ }^{12}$}

Em face do diagnóstico estabelecendo uma hierarquia entre os problemas que afetam a instituição, que medidas são vistas como mais adequadas e eficientes para resolver aqueles problemas, contribuindo para um bom funcionamento da Polícia Civil? As respostas para essa questão estão sintetizadas na Tabela 11, que, além de apresentar as diferentes soluções de acordo com o seu grau máximo de apoio, distingue as opiniões dos delegados e das delegadas.

TABELA 11: PROPOSTAS VISTAS COMO "MUITO IMPORTANTES" PARA MELHORAR O FUNCIONAMENTO DA POLÍCIA CIVIL, POR GÊNERO (EM \%)

Promulgação da Lei Orgânica Nacional da Polícia Civil

DELEGADOS DELEGADAS

Eleição para delegado geral pelos integrantes da

carreira

Definição de critérios objetivos para promoção e

ocupação de cargos de direção

Inamovibilidade dos delegados

$\begin{array}{cc}84,6 & 73,7 \\ 80,0 & 70,5 \\ 78,5 & 76,1 \\ 78,4 & 71,9 \\ 39,5 & 43,5 \\ 32,9 & 23,4 \\ 18,9 & 13,5 \\ 3,7 & 3,3\end{array}$

independente

Criação de um órgão especial de controle externo da

polícia

Controle externo da atividade policial pelo

Ministério Público

3,7

3,3

Fonte: Pesquisa Idesp, 2002, “Quem são e o que pensam os delegados de polícia”.

A promulgação da lei orgânica é apoiada por um grande número de entrevistados, sendo vista por $82,6 \%$ do total de integrantes da amostra como muito importante para melhorar o funcionamento da Polícia Civil. Há, contudo, diferenças estatisticamente relevantes ${ }^{13}$ quando são examinados os percentuais relativos aos homens e às mulheres. Observe-se que, entre os

\footnotetext{
${ }^{12}$ Para uma discussão aprofundada das propostas em questão no sentido de melhorar o funcionamento da Polícia Civil e da segurança pública, ver o capítulo de Arantes e Cunha, neste volume.
}

${ }^{13}$ Teste de chi-quadrado, a $5 \%$. delegados, essa é a proposta que recebe o maior percentual de apoio (84,6\%). Já entre as delegadas, essa proposta cai para a segunda colocação, vindo atrás daquela que prevê a definição de critérios objetivos para promoção e ocupação de cargos de direção. Isso não significa que não haja também entre as delegadas um alto índice de apoio à promulgação da lei orgânica, mas que é significativamente menor a proporção de mulheres que considera essa proposta muito importante.

As diferenças entre as posições defendidas por delegados e por delegadas também se expressam nas seguintes propostas: eleição para delegado geral pelos integrantes da carreira; inamovibilidade dos delegados; e corregedoria da polícia como carreira independente. Em todos esses casos, é significativamente maior o apoio masculino. Muito embora não haja diferença expressiva entre os dois grupos no que se refere à proposta que institui critérios objetivos para a promoção e ocupação de cargos de direção, delegadas entrevistadas tendem a ver essa medida como muito importante, uma vez que teria, na opinião delas, um potencial profilático, no sentido de eliminar ou diminuir os efeitos do preconceito contra as mulheres. Assim, justificando a relevância dessa proposta, dissenos uma delegada em São Paulo:

[...] caso houvesse critérios objetivos, as mulheres não seriam discriminadas dentro da carreira. Você pode ver que as mulheres não ocupam os postos mais altos. Aqui em São Paulo, as mulheres entram na polícia, mas dificilmente sobem.

Destaque-se, ainda, o alto percentual de rejeição de ambos os gêneros à proposta que prevê o controle externo da atividade policial pelo Ministério Público - 79,5\% dos delegados e 78,0\% das delegadas julgamna pouco importante ou sem importância para melhorar o funcionamento da Polícia Civil.

No geral, metade das propostas para melhorar o funcionamento da Polícia Civil é avaliada de forma distinta por homens e mulheres. Efetivamente, do rol de propostas apresentadas, em cinco há concordância entre os dois grupos e em outras cinco não. 
A singularidade estadual manifesta-se nos seguintes traços:

a) Embora em todas as unidades da federação seja sempre muito alta a proporção de delegados que veem na promulgação da lei orgânica uma medida indispensável para melhorar a Polícia Civil, no Amapá e em Pernambuco trata-se praticamente de uma unanimidade entre os homens (95\% e 96,7\%, respectivamente). Apenas as delegadas do Amapá manifestaram semelhante grau de apoio. Nos demais estados, a proporção de mulheres fortemente favoráveis é sempre inferior à verificada entre os homens, caindo significativamente no Rio Grande do Sul (50\%), no Paraná $(55,6 \%)$ e em São Paulo $(59,4 \%)$.

b) $\mathrm{O}$ apoio à eleição para o cargo de delegado geral é muito variado entre os estados. Os maiores índices de delegados favoráveis à proposta estão em São Paulo $(86,4 \%)$ e no Rio de Janeiro $(84,1 \%)$, em contraste com seus colegas de Goiás $(57,4 \%)$ e Pernambuco $(52,6 \%)$. Entre as delegadas, sobressaem as do Distrito Federal, local em que todas sustentam tal ideia. Esse percentual reduz-se consideravelmente nas demais unidades da federação, caindo para a metade em Pernambuco e para apenas 44,4\% no Paraná.

c) A proposta que institui critérios objetivos para promoção e ocupação de cargos de direção distingue três grupos de delegados, quando se considera o estado de atuação. No primeiro estariam os que manifestam o mais forte apoio (mais de $81 \%$ ), formado pelos integrantes do sexo masculino do Amapá, da Bahia, de Pernambuco, do Paraná e de São Paulo e pelas delegadas do Amapá, da Bahia, do Distrito Federal, de Goiás, do Paraná e de São Paulo. O segundo grupo, com percentuais na casa dos $70 \%$, conta com o conjunto dos integrantes do Rio de Janeiro e com as delegadas de Pernambuco. No último grupo, verificam-se, comparativamente, as menores proporções. Esse conjunto inclui os delegados do Distrito Federal, de Goiás e do Rio Grande do Sul e as delegadas atuando em São Paulo e no Rio Grande do Sul. A maior divergência interna é encontrada no Distrito Federal: $65,4 \%$ dos delegados julgam essa proposta muito importante versus $92,3 \%$ das mulheres.

d) A questão da inamovibilidade dos delegados opõe delegados e delegadas exercendo suas atividades no Paraná, em São Paulo e no Rio de Janeiro. Nos dois primeiros estados é significativamente mais alta a proporção de homens que manifestam seu apoio à proposta. No caso do Rio de Janeiro, inverte-se: é maior o percentual de delegadas.

e) A menor proporção de apoio à expansão das delegacias especializadas está no Rio de Janeiro, onde $20,7 \%$ dos delegados e $18,2 \%$ das delegadas consideraram essa proposta muito importante para melhorar o funcionamento da Polícia Civil. Em contraste, essa foi a posição defendida por mais da metade dos integrantes do Amapá e do Distrito Federal e pelas delegadas da Bahia.

f) A proposta que visa estabelecer a corregedoria como carreira independente divide muito, tanto os delegados como as delegadas, não se formando em nenhuma das posições maiorias absolutas (metade mais um). Assim, em Goiás, a maioria relativa, somando mais de um terço dos homens, considera essa proposta pouco importante. Já no Paraná e em Pernambuco, o maior número julga-a muito importante (cerca de 40\%). Entre as delegadas, apenas no Distrito Federal, no Paraná, em Pernambuco e no Rio Grande do Sul, é possível constatar que mais da metade das integrantes julga de forma semelhante essa proposta. Nos dois primeiros casos, como muito importante; em Pernambuco como importante; e no Rio Grande do Sul como pouco importante.

g) A ausência de maiorias absolutas entre os delegados marca também a proposta que prevê a criação de um órgão de controle externo. Além disso, parece significativo o fato de a maior parte não se opor de forma intensa ou moderada, como acontece em outras corporações do sistema de justiça ${ }^{14}$. Em Pernambuco, a maioria relativa de 33,3\% dos homens julga essa proposta muito importante; consideram-na importante o maior percentual relativo dos atuantes no Amapá, na Bahia, no Distrito Federal, no Paraná, no Rio de Janeiro, no Rio Grande do Sul; e pouco importante a maioria relativa dos delegados de Goiás e de São Paulo. Em contraste, entre as delegadas há maiorias absolutas em Goiás, em Pernambuco e no Rio Grande do Sul, com pouco mais da metade das mulheres considerando a proposta importante. No caso do Rio Grande

${ }^{14}$ Sobre a posição de magistrados e integrantes do Ministério Público dos estados e do Ministério Público Federal, ver pesquisas realizadas pelo Idesp. 
do Sul, chama a atenção o fato de o grupo feminino dividir-se praticamente ao meio, apoiando e rejeitando a medida.

h) O controle externo da atividade policial pelo Ministério Público tem a rejeição de $56,1 \%$ dos delegados de São Paulo e também da maioria $(53,8 \%)$ das delegadas do Distrito Federal. Em contraste, o maior apoio relativo à proposta, considerando-a importante, reúne os delegados do Distrito Federal $(29,4 \%)$ e de Pernambuco, e as delegadas de Amapá (42,9\%). O grupo masculino e o feminino apresentam posições diferentes em todas as unidades da federação, mas de forma mais significativa no Distrito Federal, onde as mulheres são comparativamente muito mais contrárias do que os homens ao controle externo exercido pelo Ministério Público. Por outro lado, é também apreciável a diferença encontrada no interior do grupo masculino e do feminino.

As propostas em discussão não se restringem ao objetivo de melhorar o funcionamento da Polícia Civil. Há também um conjunto de propostas que visam aperfeiçoar a Segurança Pública e o desempenho do Sistema Penal. A posição dos entrevistados sobre esses temas encontra-se nas Tabelas 12 e 13 .

Entre as propostas listadas na Tabela 12, apenas a criação de grupos especiais na Polícia para o combate ao crime organizado recebe o apoio de expressiva maioria dos integrantes da carreira, não havendo diferenças significativas entre as opiniões emitidas por delegados e delegadas. Não se nota também divergências significativas entre os dois grupos no que se refere à maior fiscalização sobre as empresas de segurança privada. Essa proposta tem a concordância de pouco mais da metade dos homens e das mulheres. Da mesma forma, não há diferenças quanto ao apoio à implementação de conselhos comunitários de segurança pública, ainda que pouco mais da metade das delegadas veja como muito importante a medida e entre os homens esse percentual seja um pouco menor.

Delegados e delegadas apresentam, sim, opiniões muito diferentes quando se trata da unificação das polícias Civil e Militar e da criação ou fortalecimento da Ouvidoria de Polícia. No primeiro caso, é estatisticamente ${ }^{15}$

\footnotetext{
${ }^{15}$ Teste de chi-quadrado, a $5 \%$.
}

maior o número de homens que concorda com a proposta do que o de mulheres e, no segundo, a proporção de delegadas quando comparada à de delegados.

Todas as propostas, como na situação anterior referente à Polícia Civil, são apreciadas de forma diferenciada quer quando se observa os integrantes da carreira por estado, quer quando o foco está no gênero. Assim, a criação de grupos especiais na polícia para o combate ao crime organizado distingue os delegados em dois grupos, segundo o percentual de apoio. No primeiro - mais fortemente favorável à proposta - estão os delegados do Amapá, do Distrito Federal, de Goiás, do Paraná e de São Paulo e apenas as delegadas de São Paulo. O segundo grupo reúne os delegados da Bahia, de Pernambuco, do Rio de Janeiro e do Rio Grande do Sul e todas as delegadas, com exceção das que atuam em São Paulo.

TABELA 12: PROPOSTAS COM CONCORDÂNCIA TOTAL PARA MELHORAR A SEGURANÇA PÚBLICA, POR GÊNERO (EM \%)

Delegados Delegadas

Criação de grupos especiais na polícia para o

combate ao crime organizado

Maior fiscalização sobre as empresas de segurança

privada

Implementação de conselhos comunitários de segurança pública

Unificação das polícias Civil e Militar

Criação/fortalecimento da Ouvidoria de Polícia

Fonte: Pesquisa Idesp, 2002, “Quem são e o que pensam os delegados de polícia”.

A implementação de conselhos comunitários de segurança pública tem maior contingente de adeptos entre os delegados e as delegadas do Amapá e de Pernambuco. Por outro lado, é consideravelmente menor o grupo formado pelos homens do Rio Grande do Sul e pelas mulheres do Paraná. No primeiro caso, apenas dois em cada dez delegados julgam que essa proposta é muito importante e no Paraná somente uma em dez delegadas.

A iniciativa que prevê a unificação das polícias Civil e Militar divide os delegados, formando posições opostas. Assim, enquanto a maioria dos homens do Paraná e do Amapá (86,4\% e 75\%, respectivamente, somando-se os que concordam totalmente com os que concordam em termos) defende a 
proposta, pouco mais da metade dos que atuam em Goiás manifestam resistência. Em relação às delegadas, também é possível constatar diferenças: as do Amapá são proporcionalmente mais favoráveis, enquanto as de Goiás, de Pernambuco e Rio Grande do Sul são muito mais desfavoráveis.

Há acentuado contraste nas posições compartilhadas pelos integrantes da carreira no que tange à criação e/ou fortalecimento da Ouvidoria de Polícia. De um lado, defendendo a proposta, estão largas maiorias (cerca de $70 \%$ ) dos delegados do Distrito Federal e de Pernambuco e, de outro, um grupo relativamente pequeno em São Paulo (apenas 12,5\% julgaram essa medida fundamental para melhorar a segurança pública). Entre as delegadas, as mais entusiásticas são as de Pernambuco e as menos as do Rio Grande do Sul e de São Paulo (somente cerca de 19\% concordam totalmente).

Quanto ao conjunto de propostas relativas ao sistema criminal (Tabela 13), é quase unânime o apoio às seguintes iniciativas: a que prevê o plantão judiciário de 24 horas; a que permitiria ao delegado de polícia realizar busca domiciliar sem mandado judicial; a que instalaria juizados especiais criminais nas delegacias de polícia. Por outro lado, há extensa rejeição à medida que criaria grupos de investigação e a que transferiria a direção dos trabalhos de investigação para dentro do Ministério Público. Notam-se maiorias, ainda que mais reduzidas, na avaliação das demais propostas, quer concordando quer discordando.

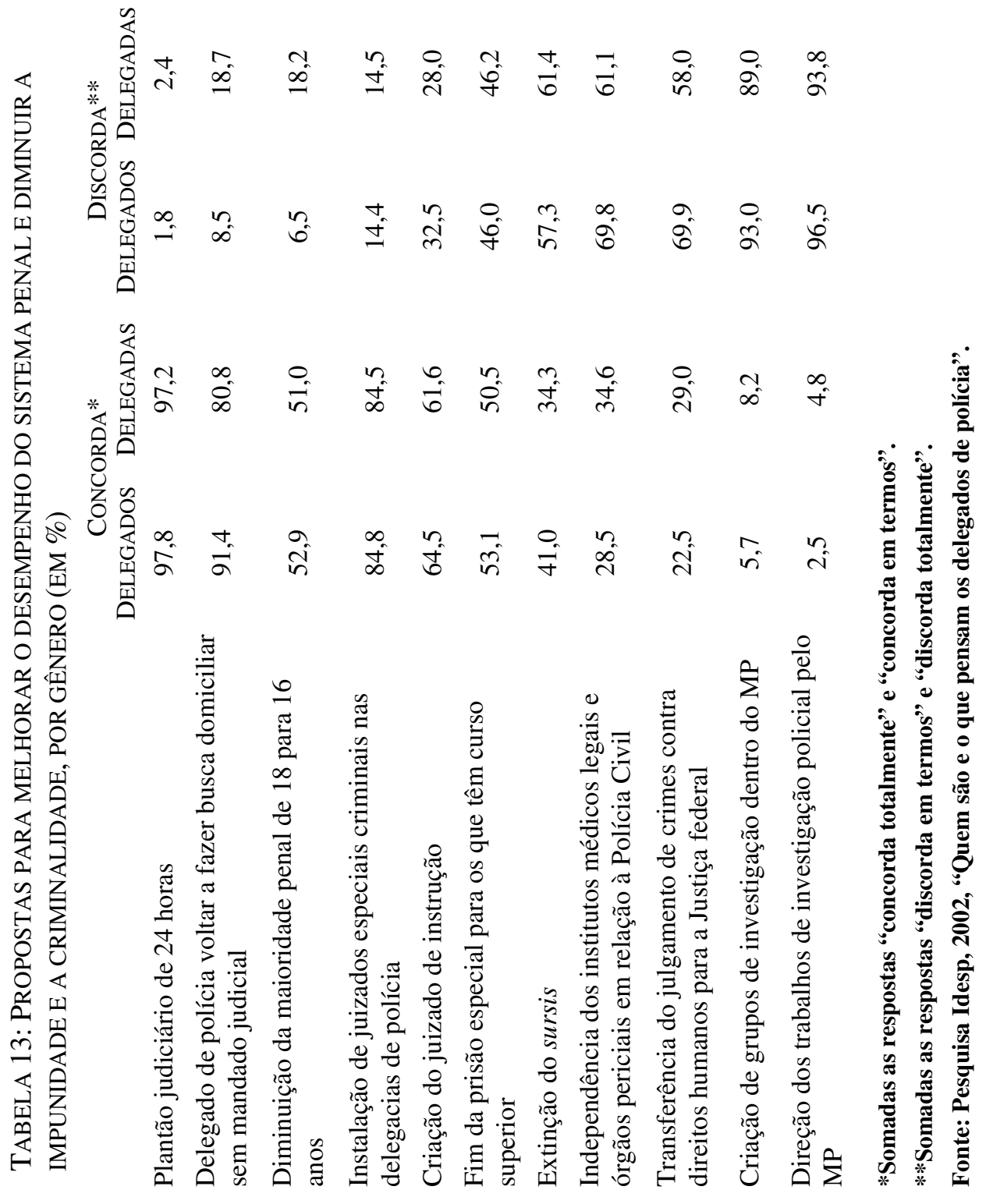


O grupo masculino difere do feminino expressando posições diversas apenas na hipótese de realização de busca domiciliar sem ordem judicial. Os delegados tendem a concordar mais com essa proposta do que as delegadas. Em relação às demais propostas não há diferenças estatísticas significativas entre delegados e delegadas.

Essas constatações, contudo, perdem força quando são examinados os percentuais no interior dos estados pesquisados. Dessa ótica, ressaltamse os seguintes contrastes:

a) Enquanto todos os integrantes do Amapá e todas as delegadas do Distrito Federal e de Goiás, sem exceção, consideram o plantão judiciário de 24 horas muito importante, esse apoio cai para $82 \%$ entre os delegados da Bahia e para $87 \%$ entre as delegadas do Rio de Janeiro e de São Paulo.

b) $\mathrm{O}$ apoio incondicional à possibilidade de busca domiciliar diferencia os delegados de Goiás dos de Pernambuco. No primeiro caso, por ser muito maior a proporção de favoráveis $(89,4 \%)$ e, no segundo, por ser muito menor $(33,9 \%)$. Quanto às delegadas, o grupo do Amapá $(78,6 \%)$ posiciona-se mais favoravelmente do que a média das mulheres $(48,1 \%)$ e o de Pernambuco $(25 \%)$, significativamente abaixo.

c) A diminuição da maioridade penal opõe os delegados: enquanto a maioria dos do Amapá (70\%) concorda com a proposta de redução, a maioria relativa dos atuantes na Bahia discorda. Na maior parte dos estados pesquisados as mulheres apresentam posições diferentes das dos homens. O maior contraste está em Pernambuco. Enquanto 52,5\% dos homens concordam totalmente com a medida, esse percentual cai para apenas $20 \%$ entre as mulheres. Mas as pernambucanas distinguemse também de suas colegas atuando em outros estados, nos quais o apoio à iniciativa envolve sempre um grupo muito maior de delegadas.

d) A concordância com a instalação de juizados especiais criminais nas delegacias de polícia divide os homens. A mais clara distinção aparece quando se compara os delegados de Goiás com os do Rio Grande do Sul. Em Goiás, a maioria (61\%) abraça totalmente a ideia, enquanto no estado sulino essa proporção míngua para quase a metade (32\%). Entre as mulheres também há diferenças expressivas: $83,3 \%$ das delegadas do
Distrito Federal concordam inteiramente com a proposta contra apenas $10 \%$ no Rio Grande do Sul.

e) Delegadas divergem de seus colegas homens no que tange à criação do juizado de instrução nos seguintes estados: Paraná, Rio de Janeiro e Distrito Federal. No Distrito Federal e no Paraná é significativamente superior o percentual de mulheres que concorda totalmente e em termos com a proposta $(66 \%$ das delegadas versus $45 \%$ dos delegados e $99 \%$ das delegadas versus $70 \%$ dos homens, respectivamente). No Rio de Janeiro, diferentemente, as mulheres são menos entusiastas do que os homens ( $28 \%$ versus $52 \%)$. No interior do grupo feminino, a maior discrepância quanto à concordância tota se dá entre as delegadas de São Paulo $(31,3 \%)$ e do Rio Grande do Sul (10\%). Já no time masculino, contrastam os de São Paulo $(35,5 \%)$ com os do Distrito Federal $(19,6 \%)$.

f) A proposta que prevê o fim da prisão especial para os que têm curso superior é apreciada de forma diferente no interior de alguns estados e quando são comparados os grupos divididos por gênero. Assim, entre os delegados, o maior contingente de favoráveis está no Amapá e o menor no Distrito Federal. As delegadas, em geral menos favoráveis à proposta do que os homens, mais simpáticas à ideia atuam no Rio de Janeiro e na Bahia e as menos em Pernambuco e no Paraná. As diferenças quanto ao apoio máximo, entre os integrantes de um mesmo estado, são expressivas no Amapá (65\% dos delegados e $49 \%$ das delegadas), em Pernambuco (56\% e 35\%) e no Paraná (58\% e 33\%).

g) Em relação à extinção do sursis, as opiniões são muito diferenciadas, sendo esta uma das propostas em que se nota o maior grau de divergência interna e entre os atuantes de cada estado. No grupo masculino, há alguns estados nos quais a maioria concorda com a proposta (Amapá, Distrito Federal, Goiás e Pernambuco), e outros nos quais o maior número discorda (Bahia, Paraná, Rio de Janeiro, Rio Grande do Sul e São Paulo). O mesmo se dá com o grupo feminino, ainda que nem sempre se repitam as tendências do time masculino. A maior concordância por parte das delegadas se verifica no Amapá, em Goiás e no Paraná. Em contraste, a maioria das mulheres discorda da proposta nas seguintes unidades da federação: Bahia, Distrito Federal, 
Pernambuco, Paraná, Rio de Janeiro, Rio Grande do Sul e São Paulo. É importante notar o grau de divergência entre delegados e delegadas no Distrito Federal, em Pernambuco e no Paraná. Destaque-se, ainda, que no Paraná nenhuma das delegadas entrevistadas concorda totalmente ou em termos com essa proposta.

h) Quanto à independência do IML e dos órgãos periciais em relação à Polícia Civil, também há divergências significativas entre delegados e delegadas, como também no interior de cada estado. Entre os delegados, a maior proporção de contrários está no Paraná e no Rio Grande do Sul e o maior contingente de favoráveis na Bahia e no Rio de Janeiro. Em relação às delegadas, o maior percentual de apoio está no Amapá e de discordância no Rio Grande do Sul e no Distrito Federal. No Amapá, enquanto a maior parte dos homens é contrária à proposta, a maior parcela de mulheres é favorável. Em Goiás, a maioria dos delegados é contra, enquanto as delegadas estão praticamente divididas ao meio - uma metade a favor e outra contra.

i) A proposta que prevê a transferência do julgamento de crimes contra direitos humanos para a Justiça federal também divide os delegados, apesar de a maioria posicionar-se contra. O maior grupo de adversários está em Goiás (80,5\%) e o menor no Amapá (47\%). Entre as delegadas, o maior contingente está no Rio de Janeiro $(73,9 \%)$ e o menor no Rio Grande do Sul. No estado sulino, porém, um percentual expressivo de mulheres preferiu não se pronunciar a respeito ou afirmou não possuir opinião (30\%). Homens e mulheres divergem no Rio Grande do Sul, em Pernambuco e no Paraná.

j) A hipótese de criar grupos de investigação dentro do Ministério Público é malvista pela maior parte dos delegados e delegadas, formando maiorias significativas - sempre mais do que $80 \%$. Entre os homens, a maior desaprovação dada à proposta encontra-se no Amapá e no Paraná (94\%) e entre as mulheres no Rio Grande do Sul e no Distrito Federal, onde todas as delegadas reprovam tal iniciativa. Em contraste, os menores índices de desaprovação estão entre os delegados de Pernambuco e da Bahia e as delegadas do Amapá e da Bahia.

k) A ampla rejeição à proposta que transferiria a direção dos trabalhos de investigação policial para o Ministério Público unifica delegados e delegadas, bem como os integrantes em cada um dos estados. As variações não são estatisticamente significativas, com exceção de um grupo reduzido de homens na Bahia (12\%) e de mulheres no Paraná $(11,1 \%)$ que concordam em termos com a interferência do Ministério Público na atividade de investigação.

Semelhanças e diferenças entre os grupos masculino e feminino são agudizadas ou atenuadas quando se atenta para possíveis singularidades estaduais. De fato, algumas semelhanças se dissipam e algumas igualdades transformam-se em diferenças. Isso nos permite afirmar que, no que diz respeito às várias propostas em discussão sobre a Polícia Civil, sobre a segurança pública e sobre o sistema penal, o conjunto dos integrantes da carreira de delegado de polícia forma um perfil diversificado. A pluralidade e a inexistência de um padrão são traços que se manifestam tanto quando se aprecia o gênero dos entrevistados, como quando se atenta para os estados. Ou dizendo de outro modo, a heterogeneidade não se desfaz nem em função da geografia nem devido ao fato de uns serem delegados e outras delegadas.

\section{PERFIL IDEOLÓGICO}

A inexistência de um padrão distinguindo o conjunto de integrantes da carreira segundo o gênero ou, ainda, delegados de delegadas em função da unidade da federação em que atuam imprime um perfil a essa categoria profissional muito específico. Dificilmente poder-se-ia dizer que se está diante de um grupo muito homogêneo no que se refere à percepção dos problemas da Polícia Civil e às propostas que têm por finalidade aperfeiçoar a instituição e a segurança pública. Mas, por outro lado, as diversidades não são tão acentuadas a ponto de impedir a formação de maiorias, por vezes muito expressivas.

Estaria esse perfil, de alguma forma, expressando uma diferença interna baseada em valores? Por mais problemática que seja a distinção entre posições de direita, de centro e de esquerda, ela permite traçar uma referência amplamente compartilhada. Ou seja, ainda que seja impreciso o que se entende por cada uma dessas posições, é sabido que há uma distância entre os que se consideram de direita, de centro e de esquerda, em relação a uma série de questões. A despeito, pois, das muitas limitações, o conhecimento sobre o perfil dos delegados e delegadas enriquece-se com a adição de mais essa informação. O autoposicionamento dos entrevistados consta da Tabela 14. 
TABELA 14: POSICIONAMENTO IDEOLÓGICO, POR GÊNERO (EM \%)

$\begin{array}{lccc} & \text { DELEGADOS } & \text { DELEGADAS } & \text { TOTAL } \\ \text { Esquerda } & 2,4 & 2,5 & 2,4 \\ \text { Centro-esquerda } & 24,0 & 25,2 & 24,2 \\ \text { Centro } & 49,1 & 53,5 & 49,9 \\ \text { Centro-direita } & 21,3 & 16,3 & 20,5 \\ \text { Direita } & 3,1 & 2,5 & 3,0\end{array}$

Fonte: Pesquisa Idesp, 2002, “Quem são e o que pensam os delegados de polícia”.

Sublinhe-se - reforçando o argumento - que essa qualificação é tão largamente difundida e em regimes democráticos tão abertamente expressa que apenas $2,8 \%$ do total de entrevistados disseram não ter opinião a respeito ou não quiseram responder à questão. Dado o pequeno percentual de delegados e de delegadas que não se autoclassificaram, para efeitos de exposição, foram consideradas válidas somente as respostas que marcaram uma entre as alternativas: esquerda, centro-esquerda, centro, centro-direita e direita (92,2\% dos entrevistados).

A maioria dos entrevistados considera-se de centro $(49,9 \%)$ e os demais dividem-se quase que ao meio entre os dois opostos. As posições de centro-esquerda e de esquerda são identificadas por $26,6 \%$ e as de centrodireita e de direita por $23,5 \%$. Não há diferenças estatisticamente significativas entre o posicionamento dos delegados e o das delegadas.

Essas semelhanças, contudo, desaparecem quando se fixa o olhar sobre os estados:

a) Esquerda: o maior grupo de delegados que se considera de esquerda está no Amapá $(15,8 \%)$, enquanto no Distrito Federal e no Paraná nenhum se vê em tal posição. Quanto às mulheres, na maior parte dos estados, nenhuma delegada se classifica como de esquerda. Apenas na Bahia (4,9\%), no Distrito Federal (7,7\%) e em Pernambuco (10\%) um pequeno número enquadra-se nessa posição.

b) Centro-esquerda: essa é a posição que reúne o maior número de delegados do Amapá $(36,8 \%)$, contrariando a tendência nacional que abriga o maior contingente no centro. Estão também acima da média geral os delegados do Rio de Janeiro $(31,8 \%)$, do Rio Grande do Sul $(30,4 \%)$ e de Goiás $(27,7 \%)$. As mais baixas proporções estão no
Distrito Federal e em Pernambuco (15,5\% em ambos). Quanto às delegadas, sobressaem as do Rio de Janeiro, com um alto percentual nessa posição $(43,5 \%)$ e as de São Paulo por sua baixa participação nessa posição $(14,3 \%)$.

c) Centro: essa posição é reclamada pela maior parte dos delegados em praticamente todos os estados, com exceção do Amapá. O maior contingente relativo está na Bahia (56,3\%) e no Rio de Janeiro (54,5\%). A predominância dessa posição entre as mulheres tem validade para todos os estados. O maior grupo está no Distrito Federal $(66,7 \%)$ e o menor em Pernambuco (40\%).

d) Centro-direita: são grandes as variações entre os estados. Assim enquanto incluem-se nessa classificação $33,3 \%$ dos delegados do Distrito Federal, no Rio de Janeiro apenas 8\% dos entrevistados se reconhecem em tal posição. No que se refere às delegadas, com exceção das que atuam em São Paulo $(28,6 \%)$, há um menor grupo que se enquadra nessa categoria nos demais estados - sendo claramente minoritário na Bahia, no Distrito Federal e no Rio de Janeiro (sempre menos de $8 \%$ ).

e) Direita: acompanhando um traço nacional ${ }^{16}$, em que são extremamente minoritários os que se dizem de direita, são poucos os delegados que se classificam nessa posição. $\mathrm{O}$ único estado em que a direita é reclamada por um percentual digno de menção é o Amapá $(10,5 \%)$. Nas outras localidades, a proporção é insignificante, sendo inexistente no Rio Grande do Sul. Quanto às delegadas, na maior parte dos casos, nenhuma se declarou nessa posição. As exceções, ainda que sempre muito minoritárias, localizam-se no Amapá $(7,1 \%)$, em Pernambuco (5\%), no Rio de Janeiro (4,3\%) e em São Paulo (3,2\%).

Vejamos, agora, se essas diferentes posições, extrapolam uma mera autoclassificação, provocando efeitos no grau de concordância ou de discordância com algumas ideias expressas em afirmações normalmente ouvidas nas ruas e muitas vezes repetidas nos meios de comunicação e por

${ }^{16}$ Pesquisas de opinião têm insistentemente mostrado que são extremamente minoritários, ou espécimes raros, os integrantes da classe política que se consideram de direita, refletindo a inclinação popular nessa direção. Igualmente, mesmo em setores da elite é pequena a proporção da direita. 
publicações não especializadas. Essas afirmações estão reunidas na Tabela 15, separando a opinião dos delegados da das delegadas.

Delegados e delegadas não se distinguem em suas opiniões em nove das dez afirmações apresentadas. A exceção refere-se à proposição segundo a qual a violência é inerente à função policial. Maior proporção de mulheres $(71,3 \%)$ rejeita essa frase comparativamente aos homens $(60,7 \%)$.

Observando-se, porém, a concordância segundo a posição ideológica dos entrevistados, aquelas semelhanças se desfazem ${ }^{17}$. Vejamos o efeito dos valores e se eles diferenciam os entrevistados:

a) "Bons e maus cidadãos devem ter seus direitos constitucionais respeitados": o apoio a essa afirmação não apresenta variações segundo a ideologia professada pelo entrevistado.

b) "A política de direitos humanos tem beneficiado os criminosos": a reação a essa afirmação está estreitamente relacionada ao posicionamento ideológico. Assim, os delegados de direita respondem diferente dos de centro e de esquerda e os que se consideram de centro de forma distinta dos que se percebem como de esquerda. Entre as delegadas, são distintas as reações das de esquerda quando contrastadas com as de centro.

c) "A maior parte da população não tem acesso à justiça": homens de esquerda sustentam posições diferentes dos que se dizem de centro. Já entre as delegadas, as distinções relacionam-se com a posição de direita em contraste com a de esquerda.

d) "A Constituição Federal de 1988 dificultou a atuação da Polícia Civil": delegados que se posicionam na direita respondem diferente dos de centro e dos de esquerda; os de centro, por sua vez, distinguem-se dos de esquerda. As reações das delegadas que se classificaram como de centro divergem das de esquerda.

e) "A miséria é a principal causa da criminalidade": não há variações significativas quando são comparadas as diferentes posições ideológicas professadas por delegados e delegadas. f) "A aplicação das leis sempre beneficia os privilegiados": entre os delegados, o grau de concordância dos que se consideram de esquerda é diferente dos que se dizem de centro. Entre as mulheres, a distinção por autoposicionamento ideológico não se exprime em diferenças na avaliação dessa afirmação.

g) "A polícia está distante da comunidade": delegados de esquerda diferenciam-se dos de centro e de direita no grau de concordância com essa afirmação. As avaliações das delegadas independem de seu posicionamento ideológico, não se distinguindo entre si quanto a essa afirmação.

h) "A confissão sob pressão policial é justificável nos casos de crimes hediondos": as avaliações de delegados e de delegadas não se diferenciam segundo as posições ideológicas.

i) "A democracia abalou a autoridade policial": as respostas dos delegados são variáveis de acordo com a ideologia professada. Assim, os de direita são diferentes dos de esquerda e dos de centro, os de centro diferentes dos de esquerda. Já entre as delegadas, as respostas não variaram segundo a autoclassificação no espectro ideológico.

j) "A violência é inerente à função policial": as respostas a esta afirmação não apresentam variações, isto é, o diferente posicionamento ideológico não se manifesta em diversa apreciação sobre a tese contida na afirmação.

É possível sustentar que as reações de delegados, na maior parte das questões, estão relacionadas ao posicionamento no espectro ideológico. Ou seja, a autoclassificação ideológica reflete-se na percepção das afirmações. A força dos valores é menor entre as mulheres, revelando que o grupo feminino é mais homogêneo no que diz respeito às avaliações de questões com indiscutível carga ideológica como as apresentadas na Tabela 15.

Essa conclusão pode ser igualmente testada na percepção dos fatores que influenciam a imagem negativa da Polícia Civil e na avaliação da relação da instituição com outras instituições e agentes, conforme consta das Tabelas 16 e 17.

\footnotetext{
${ }^{17}$ Trata-se de análise de variância a um critério (oneway - anova).
} 
TABELA 15: CONCORDÂNCIA TOTAL COM AFIRMAÇÕES, POR GÊNERO (EM \%)

"Bons e maus cidadãos devem ter seus direitos

Delegados Delegadas atuação da Polícia Civil" constitucionais respeitados"

"A política de direitos humanos tem beneficiado os criminosos"

"A maior parte da população não tem acesso à justiça"

"A Constituição Federal de 1988 dificultou a

"A miséria é a principal causa da criminalidade"

"A aplicação da lei sempre beneficia os privilegiados"

"A polícia está distante da comunidade"

$$
76,4 \quad 74,8
$$

$39,4 \quad 37,8$

$21,1 \quad 21,0$

$14,8 \quad 10,3$

$11,7 \quad 7,2$

$6,6 \quad 4,3$

$5,2 \quad 3,3$

$3,1 \quad 1,0$

nos casos de crimes hediondos"

"A democracia abalou a autoridade policial"

"A violência é inerente à função policial"
$41,6 \quad 34,9$

\section{Fonte: Pesquisa Idesp, 2002, “Quem são e o que pensam os delegados de polícia”.}

Acusações de corrupção são vistas como o principal fator responsável pela formação de uma imagem negativa da Polícia Civil. Contribuem também para essa imagem a exploração sensacionalista pelos meios de comunicação, o tratamento dispensado à população e a violência policial. $\mathrm{O}$ menor peso, entre todos os fatores apresentados, é atribuído às declarações de integrantes do Poder Judiciário.

Delegados e delegadas diferenciam-se significativamente em suas avaliações sobre a violência policial e sobre a exploração sensacionalista dos meios de comunicação. Todos os demais fatores são percebidos de forma muito parecida, indicando que a diferença de gênero manifestou- se somente em duas das oito alternativas.

Distinguindo-se os integrantes da carreira segundo seu autoposicionamento ideológico, nota-se que se classificar de direita, de centro ou de esquerda não produz consequências na apreciação das delegadas, mas tem relação com a resposta dada pelos delegados em cinco das alternativas. Assim, os delegados de esquerda diferem dos de centro e dos de direita na importância atribuída ao sensacionalismo dos meios de comunicação; os de direita divergem dos de centro e dos de esquerda no significado emprestado às declarações de organizações de direitos humanos bem como às declarações de integrantes do Ministério Público; os de esquerda afastam-se dos de direita no peso conferido às declarações de integrantes do Poder Judiciário; os de esquerda distanciam-se dos de centro e dos de direita na importância dada ao vínculo no passado, da instituição com o regime autoritário.

\section{TABELA 16: FATORES QUE INFLUENCIAM FORTEMENTE A IMAGEM NEGATIVA DA POLÍCIA CIVIL, POR GÊNERO (EM \%)}

Acusações de corrupção

DELEGADOS DELEGADAS

Exploração sensacionalista pelos meios de

comunicação

Tratamento dispensado à população

$78,0 \quad 76,2$

Violência policial

Vínculo, no passado, da instituição com o regime autoritário

Declarações de integrantes do Ministério Público

Declarações de organizações de direitos humanos

Declarações de integrantes do Poder Judiciário

$59,9 \quad 71,4$

$53,0 \quad 53,8$

$50,6 \quad 62,2$

$41,0 \quad 42,9$

$32,6 \quad 26,2$

$25,1 \quad 28,2$

$20,1 \quad 20,6$

Fonte: Pesquisa Idesp, 2002, “Quem são e o que pensam os delegados de polícia”.

As diferenças de gênero não se amplificam em diversa avaliação da relação da Polícia Civil com outras instituições (Tabela 17). Como se percebe pela notas atribuídas, as discordâncias são pequenas quando se compara a pontuação elaborada pelos delegados e pelas delegadas. No geral, prevalece a concordância entre os dois grupos.

A relação da Polícia Civil com as demais instituições e com a população é vista, em média, como positiva. Os delegados avaliam como ótima ou boa a relação com o Poder Judiciário, com os grupos privilegiados da população, e com os setores desfavorecidos da população. A relação mais problemática, segundo os entrevistados, é com o Ministério Público. 


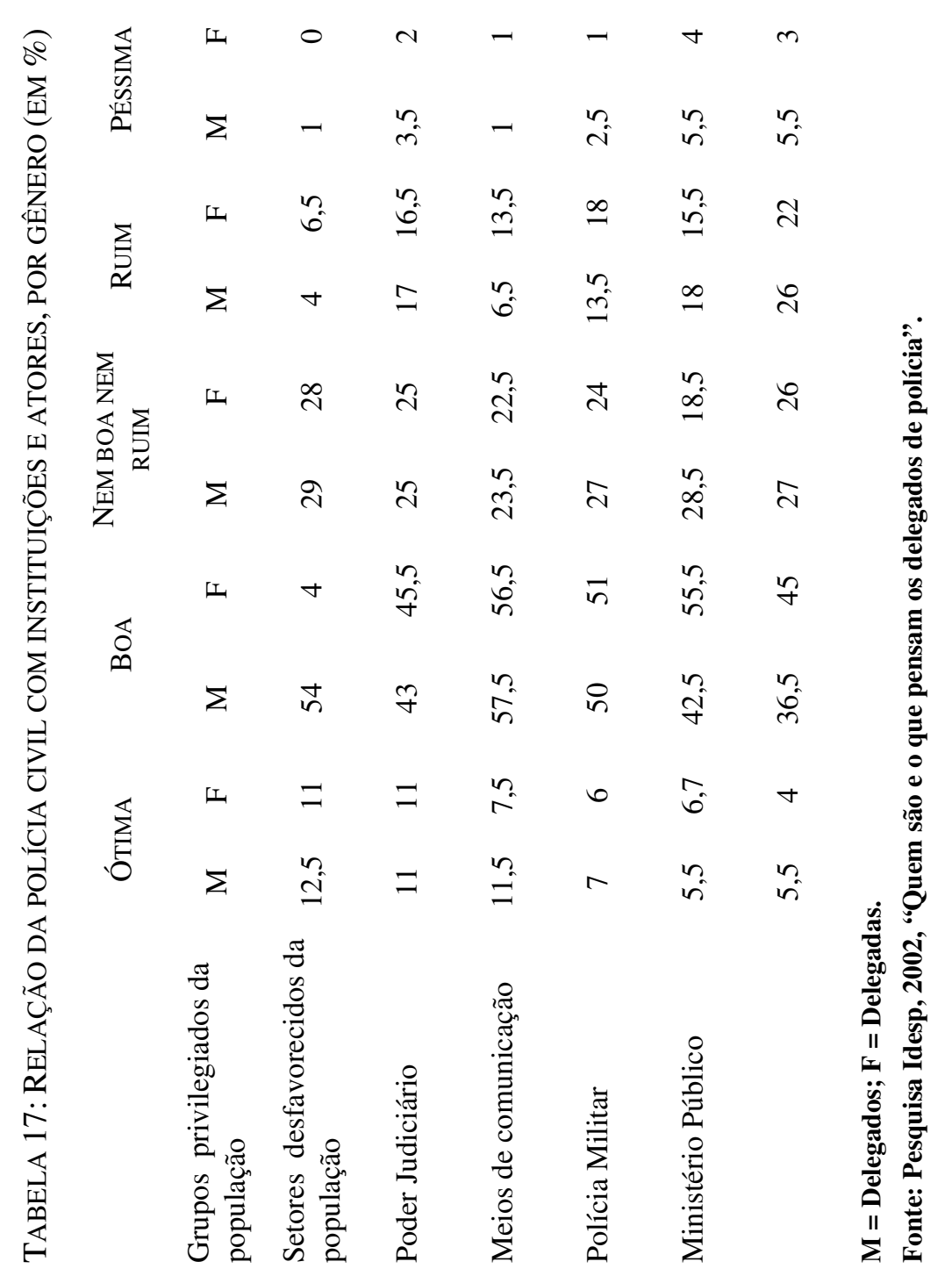

O diferente posicionamento de delegados no espectro ideológico refletese em distinta avaliação da relação da Polícia Civil com as demais instituições e agentes na maior parte das notas. Assim, com exceção da percepção sobre a relação com os grupos privilegiados da população, em todas as outras tem-se um filtro ideológico. No geral, são os delegados que se enquadram na esquerda que se diferenciam dos outros em uma proporção significativamente maior do que os de direita e os de centro em relação aos demais.

As relações da Polícia Civil com setores desfavorecidos da população e com os meios de comunicação são julgadas de forma diferente pelos que se consideram de esquerda, quando contrastados com os de direita e os de centro. Os delegados de esquerda diferenciam-se dos de centro, mas não dos de direita, na percepção das relações da Polícia Civil com o Ministério Público. A distinção com os de direita (mas não com os de centro) aparece na atribuição de notas ao Poder Judiciário. Por fim, novamente distinguemse os delegados de esquerda dos de centro na forma de avaliar a relação com a Polícia Militar.

Diferentemente do que ocorre com seus colegas do sexo masculino, as delegadas formam um grupo mais homogêneo ou menos dividido por distinções ideológicas. Ou seja, o fato de umas poucas classificarem-se como de esquerda, outras como de direita e muitas como de centro não implica diversa avaliação sobre o relacionamento de sua instituição com as demais e com grupos da população.

No conjunto de itens apresentados (Tabela 17), apenas na avaliação da relação com o Ministério Público foi possível perceber a interferência do posicionamento ideológico. Nesse caso, as delegadas que se consideram de esquerda divergem de suas colegas que se classificam como de direita.

\section{EM BUSCA DE UMA IDENTIDADE POLICIAL E FEMININA}

No sistema processual brasileiro, cabe às polícias civis estaduais a primeira atividade da persecução penal. É atribuição dos delegados investigar crimes, apontar sua autoria, realizar perícias, prender em flagrante, proceder a inquérito policial, lavrar ocorrências e termos circunstanciados. Trata-se de uma série de atos que servirão de base para o processo penal. Diz o artigo 144, parágrafo 4, da Constituição Federal: “às Polícias Civis, dirigidas por delegados de polícia de carreira, incumbem, ressalvada a competência da União, as funções de Polícia Judiciária e a apuração de infrações penais, exceto as militares". De acordo com o Código de Processo Penal, a função de Polícia Judiciária consubstancia-se principalmente por intermédio do 
inquérito policial, isto é, o conjunto de atividades realizada por requisição do Ministério Público ou direcionada ao Poder Judiciário. O inquérito policial pode ser definido como um procedimento administrativo com objetivos de esclarecer infrações penais e apurar sua autoria, tendo por finalidade colher elementos mínimos que permitam ao Ministério Público oferecer a denúncia ou a um particular ingressar em juízo com a queixa-crime ${ }^{18}$.

Essas atribuições, sem dúvida alguma essenciais em qualquer sociedade, podem facilmente ser confundidas com o uso arbitrário da força e, pior ainda, com o mundo sem lei dos bandidos. É certo que muitas das deficiências da Polícia Civil têm contribuído para a cristalização de uma imagem negativa da instituição, misturando-se em um mesmo rótulo bons e maus policiais.

As imagens negativas, repletas de preconceitos, não discriminam homens e mulheres. Todos, de forma indistinta, recebem o carimbo da truculência, da corrupção, da insensibilidade ${ }^{19}$. Ainda que se diga que todos os profissionais são forçados a conviver com estereótipos, no caso dos policiais tem-se uma soma de traços, por vezes excessivamente contraditórios. Assim, o delegado é, ao mesmo tempo, o doutor, a autoridade pública, o conselheiro, o burocrata insensível, o corrupto, o violento, o bandido-mor. A esquizofrenia daí resultante dificulta a consolidação de uma identidade, sobretudo em tempos em que se valoriza a lei, os direitos e a transparência.

No caso das mulheres, essa dificuldade é multiplicada, já que se trata de ingressar e fazer carreira em uma instituição predominantemente masculina, assentada em valores supostamente viris. Dar ordens, presidir inquéritos e saber usar arma são exigências profissionais que interagem conflituosamente com traços tradicionalmente considerados femininos. A rigor, a delegada enfrenta a combinação de dois preconceitos: os relativos à

\footnotetext{
${ }^{18}$ Embora o inquérito policial seja a atividade básica da Polícia Civil, ele vem sendo criticado pelo menos desde a década de 1940. Em 1941, por exemplo, o então Ministro da Justiça e Negócios Interiores, Francisco Campos, justificou sua permanência no sistema processual brasileiro na exposição de motivos do código de Processo Penal. Desde então, os ataques têm aumentado, com defensores de sua abolição.

${ }^{19}$ Esse estereótipo sofre grandes modificações nas diferentes classes sociais, nas áreas centrais e na periferia, nas cidades do interior e nas grandes metrópoles, para os mais escolarizados e para os menos instruídos.
}

mulher e os que dizem respeito ao policial. Assim, trata-se de ser mulher em uma profissão predominantemente masculina e de ser policial em uma sociedade que acostumou a ver a polícia como pura força. Ser brutamontes de saia não é elogio para ninguém.

Como nos disse uma delegada:

[...] a ideia que se tem de nossa profissão está contida no Senhorzinho Malta. Um homem cheio de grana, sem nenhum gosto para se vestir, cheio de joias e com um linguajar errado. Não é só a mulher que é malvista. Com a gente é pior. Porque soma duas coisas malvistas: ser polícia e ser mulher, mulher fora dos padrões. Você pode ver que em toda novela da TV Globo, o delegado sempre é cafona, cheio de correntes de ouro, relógio de ouro, anel e camisa de seda. Olha, aqui tem uma porção de delegados. Quantos se encaixam nisso? Nós, mulheres, procuramos ser femininas, sem ser afetadas. É claro que não dá para usar minissaia num ambiente em que você sabe que vai encontrar marginais. Mas isso não significa que você não deva estar bem vestida, com maquiagem, perfume [...].

Revelando preocupação semelhante, mas acrescentando às percepções externas dificuldades no interior da corporação, escreveu no questionário uma delegada do Rio de Janeiro, referindo-se às questões da pesquisa:

No próximo questionário acho interessante indagar sobre o preconceito com relação às mulheres que escolhem o cargo de delegado de polícia. Preconceito muito mais arraigado no próprio meio policial do que na população. A comunidade e os próprios criminosos têm, às vezes, mais respeito com as decisões das mulheres que ocupam esses cargos.

Uma entrevistada de São Paulo manifestou-se, por escrito, no mesmo sentido: "em reunião de delegados, a mulher, às vezes, tem que ficar calada, escutando piadinhas, como se não estivesse lá".

Parece indiscutível que o ingresso da mulher na carreira policial significou um avanço em termos de abertura da instituição para um grupo anteriormente excluído. A participação feminina não corresponde, entretanto, à eliminação de preconceitos e menos ainda que a delegada tenha trânsito livre em todos os postos da carreira. Mesmo nos estados em que a proporção de mulheres é expressiva, ela tende a concentrar-se nos graus mais baixos da hierarquia. 
No geral, o processo de socialização interna tem sido eficaz no sentido de impedir a constituição de grupos baseados no gênero. Como vimos, o perfil pessoal e social das mulheres é específico, mas não se reflete em um padrão constante de diferenças em relação a seus colegas do sexo masculino. A diversidade interna resulta de uma combinação de fatores, entre os quais o gênero, além de não ser o único, não possui um peso determinante. Por outro lado, a menor intensidade com que a ideologia divide as delegadas, mostra que as mulheres comungam percepções menos díspares sobre os problemas que afetam a instituição e a segurança pública. Desse ponto de vista, é significativo o contraste com os delegados. Possivelmente, é o alto grau com que se sentem legítimos na instituição que lhes dá o direito de ostentar posições ideológicas diferenciadas. Para os homens, o autoenquadramento na direita, no centro ou na esquerda produz reflexos em muitas de suas percepções sobre a carreira, sobre temas relacionados à segurança pública. As mulheres, ao contrário, mais "centristas", de certa forma optam por um perfil mais discreto, provavelmente mais compatível com neófitos e com minorias.

Ser delegada e ser mulher é um desafio que implica batalhar em duas frentes. Numa, contra a oposição rígida entre a lei e a força, dando à força o enquadramento da lei. Em outra, transformando os supostos traços viris em qualidades compatíveis com o feminino. Essas batalhas têm guerras em comum. Assim, na primeira frente, o campo democrático acaba por impor regras que sufocam características que o senso comum associa à virilidade, tais como a truculência e o autoritarismo. $\mathrm{O}$ que essa frente tem de específico é a efetivação do preceito de que o monopólio do uso da força só é admissível na estrita obediência da lei. Essa bandeira não distingue delegados e delegadas - é a instituição à procura de uma legitimidade democrática. Quanto à segunda frente, trata-se prioritariamente de demonstrar que a competência e o saber jurídico dependem de esforços para os quais as diferenças de gênero pouco significam. A coragem, a capacidade de mando, saber lidar com situações de risco não são incompatíveis com a feminilidade. 